\title{
New Multi Sided Platform Operator Growth - Post Funding
}

\author{
by
}

Renuka Gamage

A thesis submitted to the Faculty of Graduate and Postdoctoral Affairs in partial fulfillment of the requirements for the degree of

Master of Applied Science

in

Technology Innovation Management

Carleton University

Ottawa, Ontario

(C) 2017

Renuka Gamage 


\section{ABSTRACT}

Most of the literature on multi-sided platforms (MSP) is descriptive and examines the mature or declining stage of the company life cycle. This thesis seeks to increase our understanding of MSP startups during the growth stage - defined to start when external funding is secured. Nineteen MSP startups that were launched and funded from 2012 to 2017 were examined against a model that is developed to interpret the mathematical formulations advanced in the literature to explain affiliations among independent suppliers, customers, and MSP operators. The results suggest that funded MSP startups affiliate with four agents: third-parties, catalysts, affiliates, and sides-on-demand to strengthen their affiliations with independent suppliers and customers. The results add knowledge to the theory of new firm growth and are relevant to founders and top management teams of MSP startups because affiliations with agents may increase their likelihood of attracting resources to grow and affect MSP startups outcomes. 


\section{ACKNOWLEDGEMENTS}

I would like to express my sincere appreciation to Professor Tony Bailetti for his

valuable assistance in guiding me wisely towards completion of this thesis. Professor Bailetti acted as thesis advisor, teacher, and mentor; coaxed the very best from me and taught me what good research is all about. By showing me the benefit of the systematic process with emphasis on objectivity, my ability to infer conclusions from the research conducted has been enhanced.

I also thank the staff of the Global Cybersecurity Resource (GCR) for being a source of ideas for this thesis. With funding from FedDev Ontario's Investing in Regional Diversification Initiative, the GCR builds upon two key programs from Carleton University, i.e., the Technology Innovation Management Program (TIM) and Lead to Win (LTW), to grow companies that either focus on cybersecurity or use cybersecurity as a differentiator.

I would like to thank the members of the TIM faculty, Dr. Muegge, Dr. Weiss, and Dr. Westerlund who provided valuable feedback at my gate reviews. Without their astute support and feedback, I would not have been able to turn in the thesis I have.

I am grateful to all of those with whom I have had the pleasure to work in the TIM program, my colleagues, and TIM affiliates. With their encouraged, my life experience has been broadened. TIM Program Administrator Emily Byron provided untold support throughout the duration of my studies. A bouquet of thanks extends to all of them. 
Of course, I owe an equal measure of gratitude to my own family for their support during my pursuit of this thesis. I especially thank my husband Stanis for standing by with his constant encouragement and, equally importantly, my children, Adrian and Andina for sharing tough times, for their generous inspiration towards what I set my feet on. 


\section{TABLE OF CONTENTS}

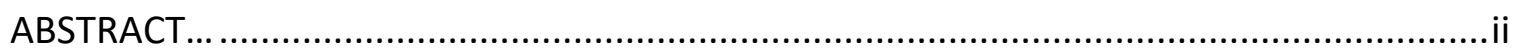

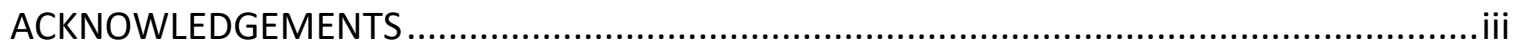

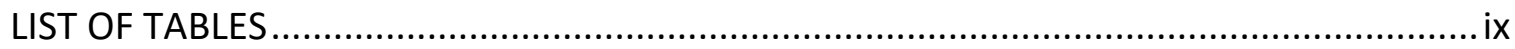

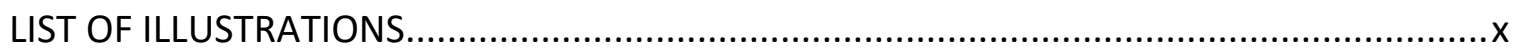

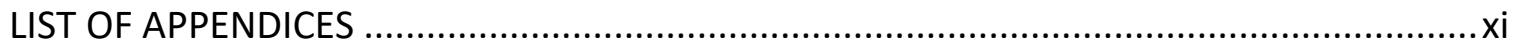

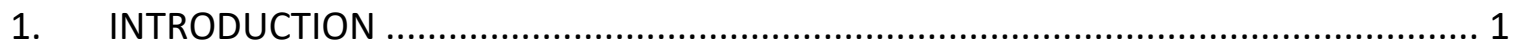

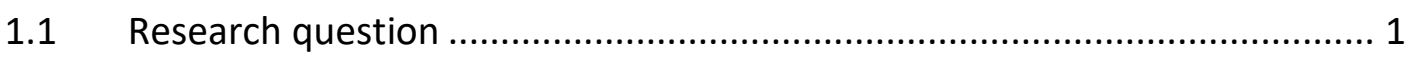

1.2 What is known about startups that operate as MSPs? ............................ 1

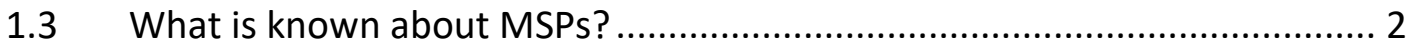

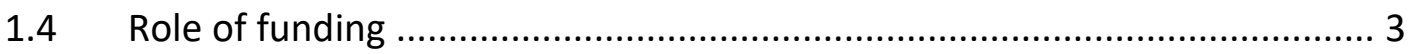

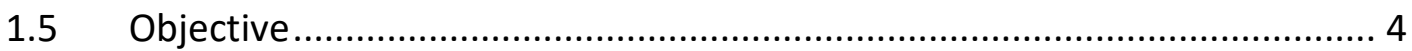

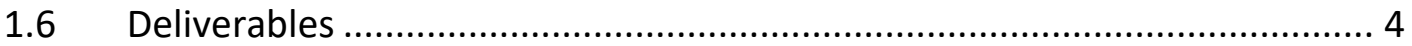

1.7 Contribution and relevance ............................................................. 4

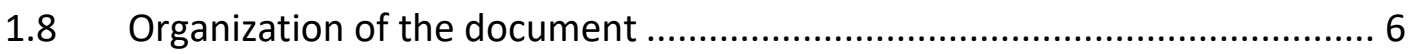

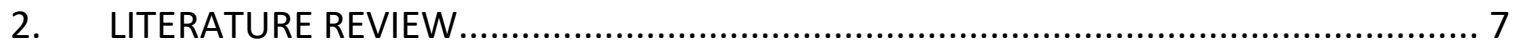

2.1 MSP logic explained based on formal mathematical formulations ............. 7

2.2 MSP logic as observed in empirical studies .......................................... 13

2.3 MSP logic as explained in descriptive essays by business writers ............. 17

2.4 The databases where MSP company data were found ........................... 20

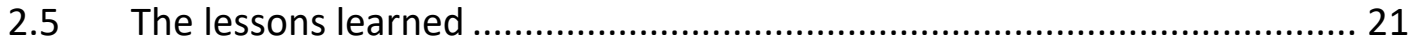

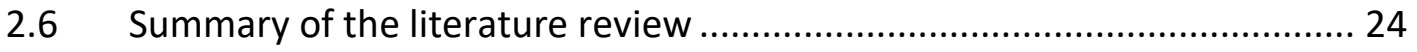




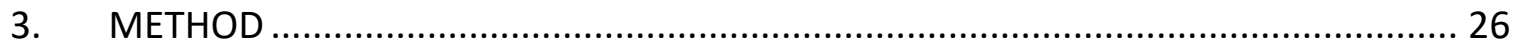

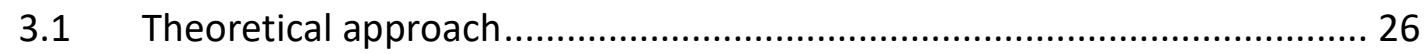

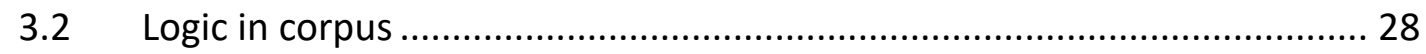

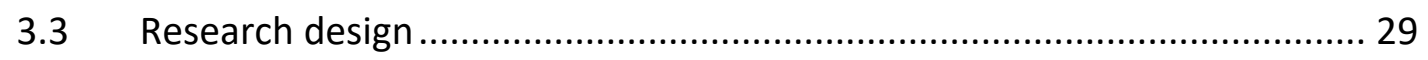

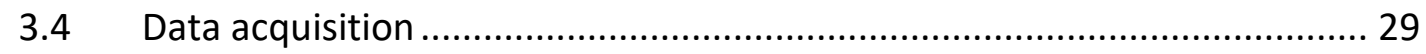

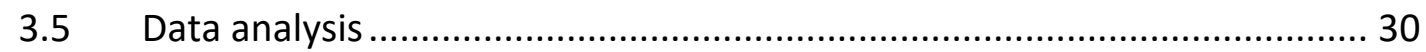

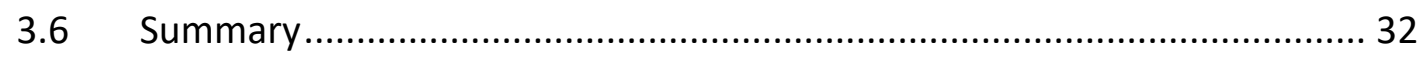

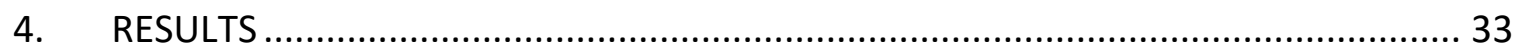

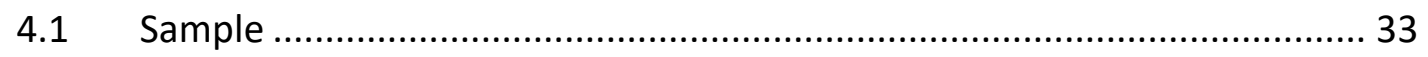

4.1.1 Sample selection process …………………................................. 34

4.1.2 Sample related information .......................................................... 35

4.2 Representation drawn from selected corpus........................................ 43

4.2.1 Agent 1: Independent .......................................................... 44

4.2.2 Agent 2: Customer ..................................................................... 44

4.2.3 Agent 3: Operator …………........................................................... 44

4.2.4 Affiliation 1: Independent-Customer Affiliation ............................... 45

4.2.5 Affiliation 2: Independent-Operator Affiliation ................................ 45

4.2.6 Affiliation 3: Customer-Operator Affiliation ..................................... 46

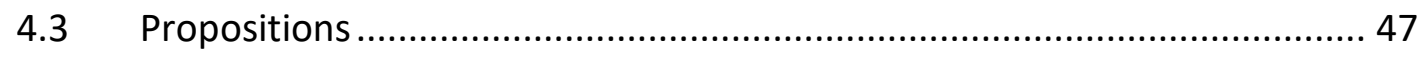

4.4 New elements drawn from data............................................................... 47

4.4.1 New agent 1: Third parties (Agent A) ............................................... 50

4.4.2 New Agent 2: Catalysts (Agent B) ..................................................... 50

4.4.3 New agent 3: Affiliates (Agent C) ............................................... 51 
4.4.4 New Agent 4: Side(s) on demand (Agent D) ................................. 51

4.4.5 New Affiliation 1: Third Parties - Operator Affiliation ..................... 52

4.4.6 New Affiliation 2: Catalysts - Operator Affiliation ......................... 53

4.4.7 New Affiliation 3: Affiliates - Operator Affiliation............................ 53

4.4.8 New Affiliation 4: Sides on Demand - Operator Affiliation............... 53

4.5 Representation drawn from corpus and data ....................................... 54

4.6 Propositions around the new model .................................................. 55

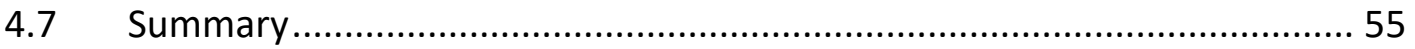

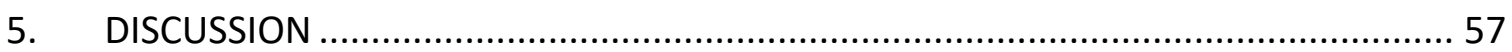

5.1 MSP logic from corpus and findings of the research............................. 57

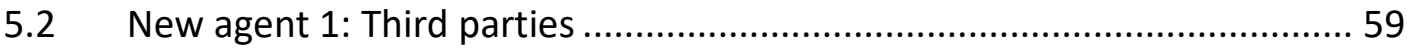

5.2.1 Affiliation with third parties to add participants: ..........................60

5.2.2 Affiliation with third parties to provide additional services to their

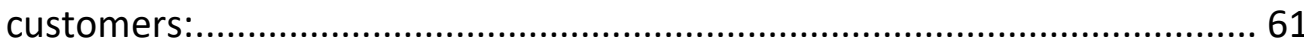

5.2.3 Affiliation with third parties to handle regulatory and compliance

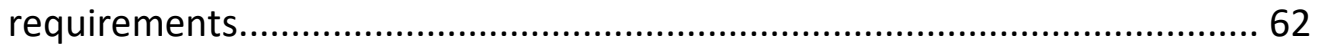

5.2.4 Affiliation with third parties to track and verify ..........................6 62

5.2.5 Affiliation with third parties to provide amenities to Catalysts......... 63

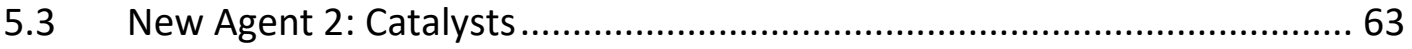

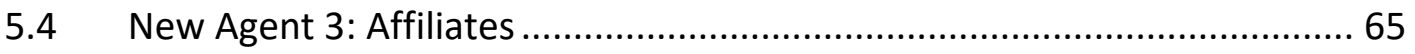

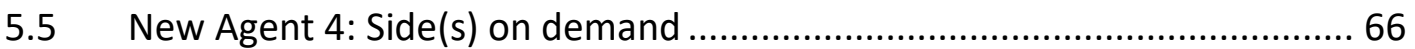

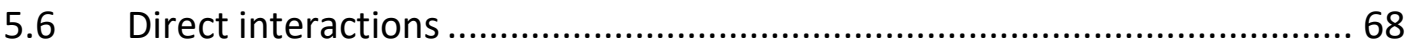

5.7 Discussion of results relating to literature ............................................. 70 


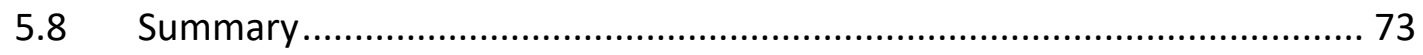

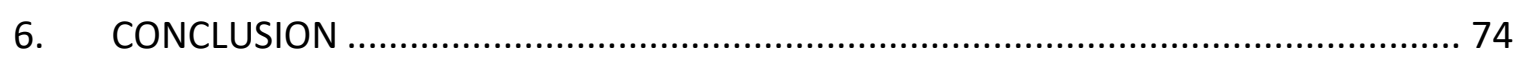

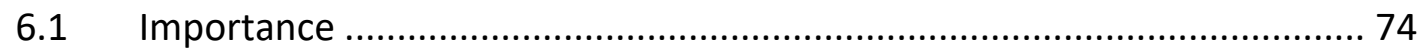

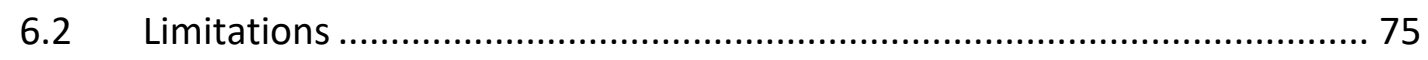

6.3 Suggestions for future work ........................................................... 75

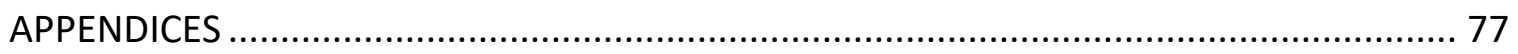

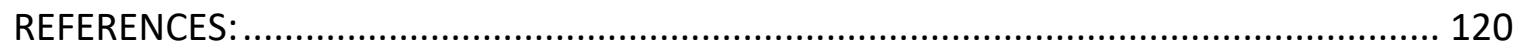




\section{LIST OF TABLES}

Table 2. 1 The aspects of an MSP logic that were attempted to explain mathematically

Table 2.2 The aspects of an MSP logic that were explained along with empirical

evidence

Table 2.3 The aspects of an MSP logic that were explained in descriptive essays/publications

Table 2.4 the aspects that were searched about and the sources of information........ 20

Table 3. 1 Method the research was conducted

Table 4. 1 Companies launched and grown as multi-sided platforms between 2012-

2017 included in the sample

Table 4. 2 Companies included in the sample by location of headquarters and

information on funds raised 40

Table 4. 3 Breakdown of companies in sample by country 42

Table 4. 4 New agents identified by examining the data on 19 companies 48 


\section{LIST OF ILLUSTRATIONS}

Figure 3. 1 Representation from corpus showing key elements and relationships ...... 29

Figure 3. 2 Representation of data analyses based on Object-Oriented Analysis

technique

Figure 4. 1 Sample selection process satisfying five criteria and the sources where

companies were drawn from.....

Figure 4. 2 Representation of the logic of an MSP extracted from the selected corpus43

Figure 4. 3 Representation drawn from corpus and data 54

Figure 5. 1 Representation of the affiliations between MSP Operator and Third Parties

Figure 5. 2 Representation of the affiliation between MSP Operator and Catalysts ... 64

Figure 5. 3 Representation of the affiliation between MSP Operator and Affiliates .... 66

Figure 5. 4 Representation of the affiliation between MSP Operator and the Sides on

Demand

Figure 5. 5 Affiliations between all agents that enhance the direct interaction between Independents and Customers 72 


\section{LIST OF APPENDICES}

Appendix 1: Funding and estimated revenue for 19 companies included in the sample.77 Appendix 2: Data for the three agents and three affiliations collected for 19 companies included in sample...

Appendix 3: evidentiary data to findings on relationships among three main agents and each of the new agents for the 19 companies included in the sample........98

Appendix 4: Data for the four new agents and four new affiliations collected for 19 companies included in the sample ..........................................................107 


\section{INTRODUCTION}

\subsection{Research question}

Growing a new startup is different from growing an existing firm. Growing a pipeline business is different from growing a multi sided platform (MSP) business. Pipeline businesses contract with or purchase from suppliers, or create goods/services and sell to customers. MSPs enable direct interactions between independent suppliers and customers where both sides are affiliated with the platform. Provided most of the literature on MSPs focus on later stage of a company life cycle, much less is known about how to grow a new MSP startup. Growth stage is defined to start when external funding is secured and how a startup that operates as a MSP grows after it receives external funds (e.g., seed, series A, convertible, or debt financing) needs to be understood. The research question addressed in this thesis is: how does a startup that operates as an MSP increase its revenue during the post-funding growth stage. The answer to the research question will contribute to the theory and practice related to new MSPs.

\subsection{What is known about startups that operate as MSPs?}

The extant literature on MSPs examine the mature stage of the company life cycle than on startups designed to operate as MSPs from inception (Hagiu, 2007; 2014). The literature focuses on how later-stage MSP companies attract and retain customers, price, and govern (Evans, 2009), as well as use information systems (Tan et al., 2015). How early stage MSP companies grow revenue, value and importance 
is not well understood. Hagiu and Wright (2015b) suggest early-stage startups may function in vertically integrated (VI) mode first before transitioning to MSP mode due to their inability to establish a market presence. Airbnb, Etsy, and Uber concentrated on getting the service side of the equation first, and customer side second (HBS case, 2016) and worked hard to match early customers with early suppliers to identify what made them resonate most with the sides. It is not well understood the logic of growing a MSP startup during growth stage.

\subsection{What is known about MSPs?}

Noteworthy progress in understanding how MSPs work has been made in terms of explaining how the economics of MSPs differ from the economics of the more traditional modes of operation such as supplier, input supplier, and reseller (Eisenmann et al., 2006; Hagiu, 2007; 2014; Hagiu and Wright, 2015b; 2015c; Evans and Schmalensee, 2016). The MSP literature identifies strategies in building critical mass, establishing high switching costs, governance, right pricing, avoiding envelopment (the threat of becoming obsolete due to moving into another market combining its functionality to form a multi-platform bundle), security concerns, and positioning of stakeholders. Hagiu and Wright (2015a; 2015b; 2015c) explain the trade-offs between operating as an MSP versus operating a business in traditional forms, and the allocation of control rights referring to the choice that an existing organization would make in the transition to a MSP mode. Evans and Schmalensee (2016) argue that one sided theory involving one type of customer does not apply 
to Multi sided platforms. MSPs are constructed differently, the sides and their ties can be arranged in several configurations (Staykova and Damsgaard, 2015), and can act as a foundation to develop additional complementary products, services, and technologies (Gawer, 2009).

\subsection{Role of funding}

Funding is a major constituent of the growth of a startup. Funded startup teams find market access and credibility, and reveal opportunities to accelerate. There is a high probability that a startup may not be able to secure steady stream of revenue but decline in capital during the initial growth stage unless it receives funding. Entering growth stage, startups encounter challenges and may not generate enough funds to sustain its operations. Therefore, growth stage is defined to start when external funding is secured. Seed funding, series A, B, C funding refers to the purpose of raising capital and relates to different types of investors. Other types of funding may include convertible note and debt financing. Startups have to show their potential to raise the initial capital, and they need to have accumulated plenty of proof to raise more funding to secure subsequent funding rounds during growth stage. Therefore, how MSP startups grow after they receive external funding need to be understood. 


\subsection{Objective}

The objective of this research is to examine the agents and their affiliations that are related to growing new MSP operators during the post-funding stage.

\subsection{Deliverables}

The deliverables of this research project include:

(i) A model that explains the logic of an MSP

(ii) A set of propositions anchored around the model

(iii) Findings from examining data on startups that operate as MSPs during their growth stage

(iv) A refined model that incorporates data on startups to explain the logic of an MSP

(v) A set of new propositions anchored around the refined model

\subsection{Contribution and relevance}

This research contributes to theory as well as practice. It fills a knowledge gap by improving our understanding of MSP startups during growth stage. It makes logic explicit and add to literature. Firstly, this research interprets and advance extant literature to explain the affiliations among independent suppliers, customers, and MSP operator and provides a set of propositions; secondly, the research findings suggest four agents and their affiliations with MSP operator that strengthen the direct interaction between independent suppliers and customers contributing to 
the growth of an MSP startup, and thirdly, this research develops a model that explains these affiliations and provides a set of propositions developed around the new model. These theoretical contributions also stimulate the potential for future research. To develop testable hypotheses from the propositions anchored around the MSP logic, to suggest a taxonomy of MSPs based on MSP operator affiliations, or to clarify the funding-growth relationship would be such opportunities.

As contributions to practice, this research provides insights that support new MSP operators' decision making. The results of examining MSP startups that are funded suggest four agents and affiliations that strengthen the affiliations among independent suppliers, customers, and MSP operators and affect the interactions between independent suppliers and customers. the results emphasize the need for entrepreneurs to have developed capabilities to affiliate with different new agents. It is important for entrepreneurs to build capabilities and leverage their network to affiliate with agents other than the sides that directly interact to exchange value.

This research is relevant to academia and researchers because of the new knowledge added to the theory of new firm growth related to MSP startups during the growth stage. The results are relevant to founders and top management teams of MSP startups because affiliations with agents may increase their likelihood of attracting external resources to grow and affect MSP startup outcomes. 


\subsection{Organization of the document}

The remainder of the thesis is organized into five chapters. Chapter 2 provides a literature review. Chapter 3 describes the research method undertaken and Chapter 4 provides the results. Chapter 5 discusses the results and Chapter 6 provides the conclusions, the limitations of the research, and provide suggestions for future research. 


\section{LITERATURE REVIEW}

Chapter two is organized into six sections. Section 2.1 reviews the literature based on formal mathematical formulations explaining the logic of an MSP. Section

2.2 review the literature based on empirical studies related to MSP formulation and operation, and section 2.3 reviews the literature found as descriptive essays explaining MSPs. Section 2.4 provides a description and references to databases available to find data on MSP companies. Section 2.5 provides lessons learned, and section 2.6 summarises and concludes the literature review.

\subsection{MSP logic explained based on formal mathematical formulations}

The purpose of reviewing the literature on MSP logic based on formal mathematical formulations was to understand how MSPs work in relation to economic aspects of trade and exchange, a seller-buyer relationship. Formal mathematical modeling tried to explain given transactions in terms of traditional economics to find out what variations or similarities observed in an economic model of an MSP.

Table 2.1 provides studies that tried to explain with mathematical formulations, the trade, and exchange that happens in an MSP economic model. The aspects that economists tried to explain, the authors' standpoint and the references are listed in table 2.1. 
Table 2. 1 The aspects of an MSP logic that were attempted to explain mathematically

\begin{tabular}{|c|c|}
\hline Aspects & Standpoint and references \\
\hline $\begin{array}{l}\text { Choice of the } \\
\text { intermediary }\end{array}$ & $\begin{array}{l}\text { - A choice between functioning as a marketplace (MSP) or as a } \\
\text { reseller, to optimally position themselves between the two } \\
\text { modes with the best product/service decision in either of } \\
\text { them (Hagiu and Wright, 2015a, p.184,185) } \\
\text { - Trade-offs that exist when choosing to operate as a } \\
\text { marketplace (MSP) or reseller, that drive them towards or } \\
\text { away from MSP model relative to traditional alternatives - VI } \\
\text { firm, reseller, or input supplier (Hagiu and Wright, 2015b, } \\
\text { p.162,198) } \\
\text { - A choice between an employment mode (firm controls } \\
\text { service provision by employing professionals, sales reps, and } \\
\text { agents), and a platform mode (agents control the provision of } \\
\text { their services to customers) (Hagiu and Wright, 2015c, p.1) }\end{array}$ \\
\hline Marketplace & $\begin{array}{l}\text { - Marketplaces (MSP) enable contractual relationships } \\
\text { between buyers and suppliers (Hagiu and Wright, } \\
\text { 2015a.p.186; 2015b, p.163), and suppliers sell directly to } \\
\text { buyers using the platform (Hagiu and Wright, 2015a, p.184) } \\
\text { - Motivation benefits individual suppliers having residual } \\
\text { control rights over the provision of the service to client } \\
\text { (Hagiu and Wright, 2015a, p.184,185) } \\
\text { - Marketplaces are subclasses of MSP where two sides are } \\
\text { buyers and sellers, in an interaction of commercial trade } \\
\text { (Hagiu and Wright, 2015a, p.185) }\end{array}$ \\
\hline VI mode & $\begin{array}{l}\text { - Essentially contracts with suppliers and control the sale to } \\
\text { buyers (Hagiu and Wright, 2015a.p.186; 2015b, p.163) } \\
\text { - Coordination benefits internalize unexpected consequences } \\
\text { caused by the decisions of some professionals on another } \\
\text { professional (Hagiu and Wright, 2015b, p.164) }\end{array}$ \\
\hline Reseller & $\begin{array}{l}\text { - Resellers entirely control the transaction between the buyer } \\
\text { and the seller (Hagiu and Wright, 2015b, p.170) }\end{array}$ \\
\hline
\end{tabular}




\begin{tabular}{|c|c|}
\hline & $\begin{array}{l}\text { Resellers purchase from suppliers, choose how to sell, sell to } \\
\text { buyers and extract more rent from buyers (Hagiu and } \\
\text { Wright, 2015a, p.184,195) }\end{array}$ \\
\hline MSP & $\begin{array}{l}\text { - MSPs get two or more sides on board and enable direct } \\
\text { transactions between them (Hagiu and Wright, 2015a, p.185; } \\
\text { 2015b, p.162) } \\
\text { - The two key aspects that make MSPs special are: (i) they } \\
\text { enable direct interactions between two or more distinct } \\
\text { sides, and (ii) each side is affiliated with the platform (Hagiu } \\
\text { and Wright, 2015b, p.163) } \\
\text { - Attracts a larger number of buyers and expects a larger net } \\
\text { surplus (Hagiu and Wright, 2015a, p.195) }\end{array}$ \\
\hline $\begin{array}{l}\text { Market } \\
\text { intermediation: } \\
\text { merchant } \\
\text { mode vs. two- } \\
\text { sided platform } \\
\text { mode }\end{array}$ & $\begin{array}{l}\text { - Trade-off exists between proprietary platforms and open } \\
\text { platforms (Hagiu, 2004; 2006) } \\
\text { - Proprietary platforms internalize the consequences of } \\
\text { indirect network effects and direct competitive effects, but } \\
\text { open platforms and platform competition prevent } \\
\text { internalizing both effects (Hagiu, 2006, p.28). } \\
\text { - Two polar strategies: "merchant" mode - buy from sellers } \\
\text { and sell to buyers; "two-sided platform" mode - enable } \\
\text { affiliated sellers to sell directly to affiliated buyers (Hagiu, } \\
\text { 2007) } \\
\text { Depending on the extent of control over buyer-seller } \\
\text { interaction left to sellers, there exists a continuum of } \\
\text { intermediary types between a pure merchant and pure two- } \\
\text { sided platform (Hagiu, 2007, p.118) } \\
\text { The buyout bid is important to sellers under pure merchant } \\
\text { mode, number of consumers to trade with is important to } \\
\text { sellers under pure platform mode (Hagiu, 2007, p.120) } \\
\text { Indirect network effects (buyers - sellers), asymmetric } \\
\text { information (sellers - intermediary), investment incentives, } \\
\text { and product complementarities (or substitutability) affect } \\
\text { the trade-off between merchant mode and the two-sided } \\
\text { platform mode (Hagiu, 2007, p.129) }\end{array}$ \\
\hline $\begin{array}{l}\text { Direct } \\
\text { Interaction }\end{array}$ & $\begin{array}{l}\text { - The two or more distinct sides retain control over the key } \\
\text { terms of the interaction, as opposed to the intermediary } \\
\text { taking control of those (Hagiu and Wright, 2015b, p.163) }\end{array}$ \\
\hline
\end{tabular}




\begin{tabular}{|c|c|}
\hline & $\begin{array}{l}\text { - Key terms could be either pricing, bundling, marketing and } \\
\text { delivery of goods/services traded, the nature and quality of } \\
\text { services offered, or the terms and conditions. (Hagiu and } \\
\text { Wright, 2015b, p.163,164) }\end{array}$ \\
\hline Affiliation & $\begin{array}{l}\text { - Platform-specific investments are necessary to have a direct } \\
\text { interaction between sides and distinguish MSPs from input } \\
\text { suppliers (Hagiu and Wright, 2015b, p.164). } \\
\text { - Users of each side make platform-specific investments in the } \\
\text { form of a fixed access fee, expenditure of resources, or an } \\
\text { opportunity cost (Hagiu and Wright, 2015b, p.163) }\end{array}$ \\
\hline $\begin{array}{l}\text { Non- } \\
\text { contractible or } \\
\text { transferable } \\
\text { decision }\end{array}$ & $\begin{array}{l}\text { - Choice of the mode is a decision between control rights over } \\
\text { a non-contractible decision (Hagiu and Wright, 2015b, p.164) } \\
\text { the choice of mode is determined by the need to balance } \\
\text { two-sided moral hazard problem arising from the } \\
\text { investments that only the agents can make, and investments } \\
\text { that only the firm can make, and minimize distortions in } \\
\text { decisions that either party could control (Hagiu and Wright } \\
\text { 2015c, p.6) } \\
\text { Three types of non-contractible decisions: (i) a transferable } \\
\text { decision that is chosen by the firm or the agent, (ii) a costly } \\
\text { on-going investment that is always chosen by the firm, and } \\
\text { (iii) a costly on-going effort that is always chosen by the } \\
\text { agent (Hagiu and Wright 2015c, p.6). }\end{array}$ \\
\hline product/service & $\begin{array}{l}\text { - Individual suppliers must have a significant information } \\
\text { advantage about the best way to market the products and } \\
\text { services (Hagiu and Wright, 2015a, p.184,198) } \\
\text { - When products and services are substitutes, some suppliers } \\
\text { set prices too low putting other suppliers at risk, but when } \\
\text { services are complements, suppliers can set prices higher } \\
\text { thus mitigate the risk. MSPs benefits from selecting products } \\
\text { and services complements (Hagiu and Wright, 2015c, p.3) } \\
\text { Long-tail products to be offered when the marketplace } \\
\text { (MSP) mode has a marginal cost disadvantage (Hagiu and } \\
\text { Wright, 2015a, p.198; 2015b, p.170). Marketplaces handle a } \\
\text { broad range of unpopular products, that has lower marginal } \\
\text { cost of handling and stays long to sell (Hagiu and Wright, } \\
\text { 2015a, p.196; Hagiu and Wright, 2015b, p.170)) }\end{array}$ \\
\hline
\end{tabular}




\begin{tabular}{|c|c|}
\hline & $\begin{array}{l}\text { Products from late-stage ventures benefit MSPs (Hagiu and } \\
\text { Wright, 2015a, p.198) } \\
\text { Professional services which cannot be purchased or resold } \\
\text { (Hagiu and Wright, 2015b, p.164), and contexts where } \\
\text { creativity and human effort are needed (Hagiu and Wright, } \\
\text { 2015c, p.170) are opportunities for MSPs }\end{array}$ \\
\hline $\begin{array}{l}\text { Marketing } \\
\text { activities }\end{array}$ & $\begin{array}{l}\text { - Prices and marketing activities with limited unexpected } \\
\text { consequences on another suppliers' effort (Hagiu and } \\
\text { Wright, 2015a, p.198) } \\
\text { - Devising variable fees, or selling some products under } \\
\text { reseller mode help mitigate the effects due to unfavorable } \\
\text { expectations by suppliers (Hagiu and Wright, 2015a, p.192) } \\
\text { - MSPs have to be proficient in managing third-party } \\
\text { relationships with sides (Hagiu and Wright, 2015a, } \\
\text { p.162,171) } \\
\text { Merchant can internalize the complementarity/ } \\
\text { substitutability between seller products (Hagiu, 2007, p.123) } \\
\text { and platforms mitigate the problem by charging the sellers } \\
\text { variable fees (Hagiu, 2007, p.124) }\end{array}$ \\
\hline $\begin{array}{l}\text { Allocation of } \\
\text { control rights }\end{array}$ & $\begin{array}{l}\text { - Allocation of control rights between professionals and the } \\
\text { firm determines the mode and the responsibility for } \\
\text { marketing activities that create demand for the product or } \\
\text { service (Hagiu and Wright, 2015a, p.185,188; 2015b, p.163). } \\
\text { - Due to relative information advantage professionals retain } \\
\text { responsibility and have residual control rights for the } \\
\text { product/service (Hagiu and Wright 2015b, p.164,170) } \\
\text { - Suppliers may contract away some control rights over the } \\
\text { goods sold to customers by specifying a price limit or the } \\
\text { mode of transfer of goods to the customer. however, } \\
\text { supplier-customer direct interaction remains if supplier } \\
\text { retains the residual control rights. (Hagiu and Wright, 2015b, } \\
\text { p.170) }\end{array}$ \\
\hline $\begin{array}{l}\text { Generate } \\
\text { demand }\end{array}$ & $\begin{array}{l}\text { - Having professionals managing their individual demand } \\
\text { motivates their efforts to the highest of their expertise } \\
\text { (Hagiu and Wright, 2015b, p.162) }\end{array}$ \\
\hline Customers & $\begin{array}{l}\text { - Large and more experienced buyers best deal with suppliers } \\
\text { through MSPs because benefiting from economies of scale or }\end{array}$ \\
\hline
\end{tabular}




\begin{tabular}{|c|c|}
\hline & $\begin{array}{l}\text { verifying quality are less important to them (Hagiu and } \\
\text { Wright, 2015b, p.172) } \\
\text { Buyers purchase decision will depend on the surplus they } \\
\text { receive above the affiliation cost (Hagiu and Wright, 2015a, } \\
\text { p.195) }\end{array}$ \\
\hline $\begin{array}{l}\text { Cross-group } \\
\text { network effects }\end{array}$ & $\begin{array}{l}\text { By being affiliated with multiple sides create cross-group } \\
\text { network effects, a key defining feature of MSPs (Hagiu and } \\
\text { Wright, 2015b, p.164) } \\
\text { - MSPs create and capture value through indirect network } \\
\text { effects (Hagiu and Wright, 2015b, p.164) } \\
\text { - Consumers' taste for variety and producer competition leads } \\
\text { to Indirect network effects that are produced within the } \\
\text { system (Hagiu, 2009) }\end{array}$ \\
\hline $\begin{array}{l}\text { Chicken and } \\
\text { egg problem }\end{array}$ & $\begin{array}{l}\text { - A supplier's profit depends on how many other suppliers join } \\
\text { - more suppliers join if they expect others to join and if } \\
\text { doing so gives them non-negative profits in the resulting } \\
\text { equilibrium (Hagiu and Wright, 2015a, p.190) } \\
\text { - When more products are made available, more buyers will } \\
\text { become aware of the intermediary (through word of mouth, } \\
\text { reputation effects, or sources of information and review) or } \\
\text { the more likely a buyer who is informed will be to find other } \\
\text { products of interest through the intermediary (Hagiu and } \\
\text { Wright, 2015a, p.191; 2015b.p.165) } \\
\text { Strong supplier bargaining power leads to low participation } \\
\text { fee and motivate suppliers to join regardless of their } \\
\text { expectation about others to join (Hagiu and Wright, 2015a, } \\
\text { p.195) }\end{array}$ \\
\hline $\begin{array}{l}\text { Asymmetric } \\
\text { information } \\
\text { problem }\end{array}$ & $\begin{array}{l}\text { - Feedback systems can pool users' experience and mitigate } \\
\text { the effect of imperfect or insufficient knowledge problem } \\
\text { (Hagiu and Wright, 2015b, p.171) }\end{array}$ \\
\hline Hybrid mode & $\begin{array}{l}\text { - Suppliers retain residual control rights over some decisions } \\
\text { while the intermediary holds residual control rights over } \\
\text { some of the other, results in an intermediate business model } \\
\text { between MSP and Reseller. A similar situation arises when a } \\
\text { portion of the goods and services are controlled by the } \\
\text { intermediary (Hagiu and Wright, 2015b, p.170). }\end{array}$ \\
\hline
\end{tabular}




\begin{tabular}{|c|c|}
\hline & $\begin{array}{l}\text { - Sell all products which intermediary has an information } \\
\text { advantage in reseller mode, sell all products that suppliers } \\
\text { have an information advantage in marketplace mode (2015a, } \\
\text { p.192) } \\
\text { - The intermediary and the suppliers were each assumed to } \\
\text { have private information about the ideal choice of marketing } \\
\text { (2015b, p.170) }\end{array}$ \\
\hline $\begin{array}{l}\text { Platform } \\
\text { pricing } \\
\text { structures: }\end{array}$ & $\begin{array}{l}\text { - MSPs charge independent professionals a fixed joining fee (a } \\
\text { rent or a membership), and potentially a variable fee (Hagiu } \\
\text { and Wright, 2015b, p.166) } \\
\text { - Three new aspects of pricing structures: consumer demand } \\
\text { for product variety; platform competition; choice between } \\
\text { membership fees and usage fees (Hagiu, 2009, p.1012,1013) } \\
\text { - Two-sided market platforms exhibit different platform } \\
\text { pricing structures across different industries (Hagiu, 2004) } \\
\text { When users have a stronger preference for variety, when } \\
\text { there is uncertainty with respect to availability or a limited } \\
\text { supply, developers (suppliers) make a larger share of profits } \\
\text { (Hagiu, 2004, p.21,26,37) } \\
\text { The efficiency of a proprietary platform and an open } \\
\text { platform depends on three factors: fall of total surplus due } \\
\text { to monopoly pricing; product diversity effect; and indirect } \\
\text { network externalities (Hagiu, 2004, p.36) }\end{array}$ \\
\hline $\begin{array}{l}\text { Levels of } \\
\text { information on } \\
\text { the platform: }\end{array}$ & $\begin{array}{l}\text { - Platforms with more market power (monopoly) prefer facing } \\
\text { informed users with responsive expectations because higher } \\
\text { responsiveness lead to demand increases (Hagiu and } \\
\text { Halaburda, 2014, p.3) } \\
\text { - Platforms with less market power (facing competition) prefer } \\
\text { facing less informed users with passive expectations because } \\
\text { more information intensifies price competition (Hagiu and } \\
\text { Halaburda, 2014, p.3) }\end{array}$ \\
\hline
\end{tabular}

\subsection{MSP logic as observed in empirical studies}

Literature that dealt with empirical evidence to come up with suggestions about how to create and operate MSPs, tried to define and describe MSP mode 
accordingly. Relating to real-world cases, authors expressed slight differences that may have been difficult to notice but important to know to understand the MSP logic. Table 2.2 shows Studies that relate empirical evidence mostly through case studies along the aspects noted, authors' standpoint and references.

Table 2.2 The aspects of an MSP logic that were explained along with empirical evidence

\begin{tabular}{|c|c|}
\hline Aspects & Standpoint and references \\
\hline MSP & $\begin{array}{l}\text { - MSPs are "technologies, products or services that create } \\
\text { value primarily by enabling direct interactions between two } \\
\text { or more customer or participant groups" (Hagiu, 2014, p.71) } \\
\text { - "physical or virtual places where members of different } \\
\text { groups get together", that help parties who have something } \\
\text { valuable to exchange find each other, get together and do a } \\
\text { deal (Evans and Schmalensee, 2016) }\end{array}$ \\
\hline $\begin{array}{l}\text { Strategic issues } \\
\text { that MSPs face: }\end{array}$ & $\begin{array}{l}\text { - Adding more sides to a platform may increase positive } \\
\text { indirect network effects, but creates a more complex } \\
\text { business model (Evans and Schmalensee, 2016) } \\
\text { - Three main obstacles: the chicken-and-egg problem } \\
\text { inherent in launching, resistance from key potential MSP } \\
\text { constituents, and then the complexity of running an MSP } \\
\text { business with conflicting interests to satisfy. (Hagiu, 2014) } \\
\text { - Getting the pricing structure right is critical both for getting } \\
\text { a new MSP off the ground and for running it; platforms must } \\
\text { balance the interdependent demands of the multiple groups } \\
\text { of participants (Evans and Schmalensee, 2016) } \\
\text { - MSP's most important inputs being generating customers } \\
\text { and enabling them to interact with each other, while an } \\
\text { ordinary business focus on attracting customers and selling } \\
\text { to them on profitable terms (Evans and Schmalensee, 2016) }\end{array}$ \\
\hline Importance & $\begin{array}{l}\text { - MSPs create value by reducing search costs /transaction } \\
\text { costs or both for participants (Hagiu, 2014; Evans and } \\
\text { Schmalensee, 2016) }\end{array}$ \\
\hline
\end{tabular}




\begin{tabular}{|c|c|}
\hline & $\begin{array}{l}\text { The value to customers on one side increases with the } \\
\text { number of participants on the other sides, which results in } \\
\text { cross-side network effects (Hagiu, 2014; Evans and } \\
\text { Schmalensee, 2016) }\end{array}$ \\
\hline $\begin{array}{l}\text { Design } \\
\text { challenge }\end{array}$ & $\begin{array}{l}\text { - If the cost of building and implementing features is less than } \\
\text { the value created, include them IHagiu, 2014) }\end{array}$ \\
\hline Price & $\begin{array}{l}\text { - Treating each side of an MSP independent of others, MSPs } \\
\text { can charge (1) higher price to the group with less price } \\
\text { sensitivity, (2) more to the side that stands to benefit more, } \\
\text { (3) more to the side that extracts more value (Hagiu, 2014) } \\
\text { - Price determinants in a sharing economy allow platforms } \\
\text { charge premium prices against perceived quality signals } \\
\text { (Wang and Nicolau,2017, p.130) }\end{array}$ \\
\hline $\begin{array}{l}\text { Chicken and egg } \\
\text { problem }\end{array}$ & $\begin{array}{l}\text { - No side will join without the others, resulting a chicken and } \\
\text { egg problem (Evans and Schmalensee, 2016; Hagiu, 2014) } \\
\text { - The need to balance the interests of all sides to get them on } \\
\text { board, and keep them on board, and get them to interact } \\
\text { with each other groups (Evans and Schmalensee, 2016) } \\
\text { - The need to satisfy different platform constituents results in } \\
\text { possible constraints on MSP's ability to innovate (Hagiu, } \\
\text { 2014) } \\
\text { - Even though more sides lead to potentially larger cross-side } \\
\text { network effects, larger scale and potentially diversified } \\
\text { revenue streams, it may not be economically viable, and } \\
\text { attracting many sides might create too much complexity and } \\
\text { conflicts of interests between multiple sides (Hagiu, 2014) }\end{array}$ \\
\hline MSP strategy & $\begin{array}{l}\text { - Strategy to create an MSP would be to sell a product/service } \\
\text { to two distinct customer segments that interact with each } \\
\text { other outside the offering (Hagiu and Altman, 2017, p.98) } \\
\text { - Who your customers are? How do you interact with them? } \\
\text { How do they interact with one another? (Hagiu and Altman, } \\
\text { 2017) } \\
\text { May require enforcing some degree of technological or } \\
\text { customer experience consistency between otherwise } \\
\text { separate products and services (Hagiu and Altman, 2017) }\end{array}$ \\
\hline
\end{tabular}




\begin{tabular}{|c|c|}
\hline & $\begin{array}{l}\text { - Turn competitors to complementors (Hagiu and Altman, } \\
\text { 2017) } \\
\text { - Become an MSP by creating an offering for your customers' } \\
\text { customers that enhances the value of the product or service } \\
\text { they buy from your customers. (Hagiu and Altman, 2017) }\end{array}$ \\
\hline Regulation & $\begin{array}{l}\text { - MSPs regulate third-party actions through non-price } \\
\text { governance rules in two categories: the rules regulating } \\
\text { access to the MSP, and the rules regulating interactions on } \\
\text { the MSP (Hagiu and Baudreau, 2008; Hagiu, 2014) } \\
\text { - Unlike normal firms, the scope of strategy for platforms is } \\
\text { not limited to pricing, product design, and technology, but } \\
\text { includes control over interactions which do not happen at } \\
\text { the firm's boundaries (Hagiu and Boudreau, 2008, p.25) } \\
\text { - Non-price instruments impose rules and constraints, create } \\
\text { inducements and shaping behaviors that price instruments } \\
\text { alone cannot establish (Hagiu and Boudreau, 2008, p.3) } \\
\text { Imposing a degree of control on platform participants } \\
\text { impact on the value of the platform of controlling some } \\
\text { things itself, and giving control of other things to platform } \\
\text { participants (Evans and Schmalensee, 2016) }\end{array}$ \\
\hline Network effects & $\begin{array}{l}\text { Indirect network effects influence the way an MSP build } \\
\text { their business, design their products, run their operations, } \\
\text { and price their offerings and this interdependency of the } \\
\text { demands has being neglected in the teaching of economics } \\
\text { (Evans and Schmalensee, 2016) }\end{array}$ \\
\hline $\begin{array}{l}\text { Third-party } \\
\text { relationships }\end{array}$ & $\begin{array}{l}\text { - Proficient management of third-party relationships attract } \\
\text { and retain sides (Hagiu and Altman, 2017, p.96) } \\
\text { - Relationship management becomes more important and } \\
\text { MSPs better have business and marketing professionals in } \\
\text { leadership roles (Hagiu and Altman, 2017, p.97,100) } \\
\text { - Curation of third party products/services as to maintain } \\
\text { trust and quality of interactions becomes critical (Hagiu and } \\
\text { Altman, 2017, p.97) }\end{array}$ \\
\hline Critique & $\begin{array}{l}\text { - A fundamental problem with Economists' view that applying } \\
\text { a one-sided theory involving one type of customer, into }\end{array}$ \\
\hline
\end{tabular}




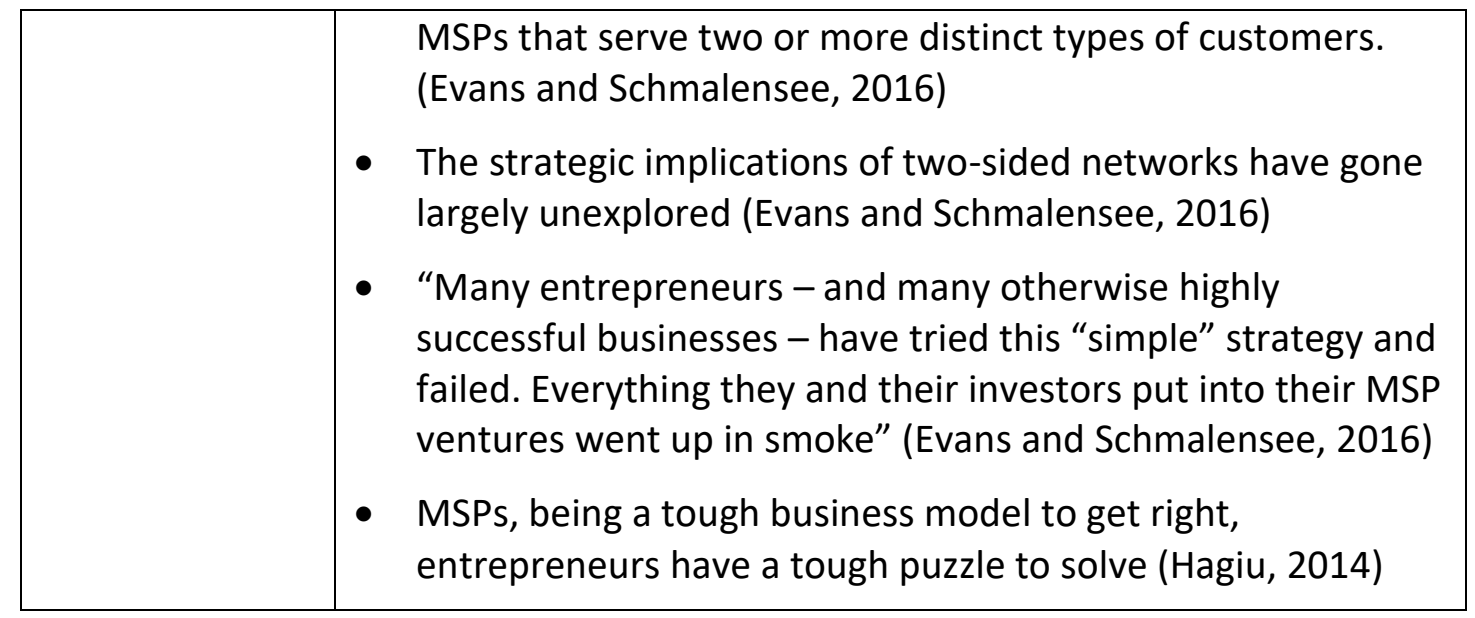

\subsection{MSP logic as explained in descriptive essays by business writers}

MSPs have become an interesting or most intriguing topic in the business world and more business writers took the opportunity to present more information to influence the business community. The purpose of reviewing the literature in the category of descriptive essays is to find out the practitioners' perspective and understanding of the MSP as a concept and an interpretation of an MSP logic. Table 2.3 shows the aspects they brought in the articles and other publications, the authors' standpoint and respective references.

Table 2.3 The aspects of an MSP logic that were explained in descriptive essays/publications

\begin{tabular}{|l|l|}
\hline Aspects & Standpoint and references \\
\hline MSP & \begin{tabular}{l} 
- $\begin{array}{l}\text { Products/services that bring together groups of users in } \\
\text { two-sided networks are platforms, that provide rules and } \\
\text { infrastructure to facilitate the two groups' transactions } \\
\text { and can take many guises" (Eisenmann et al., 2006). }\end{array}$ \\
\hline $\begin{array}{l}\text { How to get the } \\
\text { different sides }\end{array}$
\end{tabular}$\quad \begin{array}{l}\text { Get pricing right: choose a price for each side, the } \\
\text { "subsidy side" and the "money side". Encourage through }\end{array}$ \\
\hline
\end{tabular}




\begin{tabular}{|c|c|}
\hline $\begin{array}{l}\text { around an MSP } \\
\text { "on board" }\end{array}$ & $\begin{array}{l}\text { subsidization, and encourage through privilege of gaining } \\
\text { access to it (Eisenmann et al., 2006) } \\
\text { - Which side should you subsidize, and for how long? } \\
\text { (Eisenmann et al., 2006) } \\
\text { - Consumers receive value by visiting the platform; get the } \\
\text { attention, and sell that attention to businesses that aren't } \\
\text { able to get consumers' attention: sell access! (Evans, } \\
\text { 2016) } \\
\text { - Provide free services or content to attract users' } \\
\text { attention and charge advertisers for reaching to users } \\
\text { (Evans, 2016) } \\
\text { - Spend money to attract participants to one side of the } \\
\text { market (Parker et al., 2016, p.21) }\end{array}$ \\
\hline Design & $\begin{array}{l}\text { - In the traditional value chain, value moves from left to } \\
\text { right: in two-sided networks, it is both ways because of } \\
\text { distinct group of users on each side incur costs in serving } \\
\text { both groups and can collect revenue from each, although } \\
\text { one side is often subsidized (Eisenmann et al., 2006) } \\
\text { - Develop networks in which companies and people create } \\
\text { value together (Parker et al., 2016, p.32,33) }\end{array}$ \\
\hline Price & $\begin{array}{l}\text { - User sensitivity to price (Eisenmann et al., 2006) } \\
\text { - Prices need to balance the demands (Evans, 2016) } \\
\text { - Pricing strategies: (1) Subsidize quality- and price- } \\
\text { sensitive users, (2) Secure “marquee" users' exclusive } \\
\text { participation in your platform (Eisenmann et al., 2006) }\end{array}$ \\
\hline Network effects & $\begin{array}{l}\text { - Network effects, increase returns to scale, margins } \\
\text { improve as user bases grow, as opposed to the effect of } \\
\text { diminishing returns in a traditional firm where acquiring } \\
\text { new customers becomes harder at some point } \\
\text { (Eisenmann et al., 2006) } \\
\text { - With two-sided network effects, value grows as the } \\
\text { platform matches demand from both sides (Eisenmann et } \\
\text { al., 2006) } \\
\text { Platforms exhibit two types of network effects, same-side } \\
\text { effects and cross-side effects, which may be either } \\
\text { positive or negative (Eisenmann et al., 2006) }\end{array}$ \\
\hline
\end{tabular}




\begin{tabular}{|c|c|}
\hline & $\begin{array}{l}\text { - Manage all four kinds of network effects: same side (+)ve, } \\
\text { (-)ve; and cross-side (+)ve, (-)ve network effects, and } \\
\text { reinforce positive ones (Parker et al., 2016,p.21) }\end{array}$ \\
\hline Customer & $\begin{array}{l}\text { - Users are sensitive to quality (Eisenmann et al., 2006) } \\
\text { - A price increase or quality decrease affecting one side } \\
\text { affects the other as well (Evans, 2016) }\end{array}$ \\
\hline $\begin{array}{l}\text { Products and } \\
\text { services }\end{array}$ & $\begin{array}{l}\text { - Industries in which information is an important ingredient } \\
\text { (Parker et al.,2016, p.3) }\end{array}$ \\
\hline $\begin{array}{l}\text { Competitive } \\
\text { strategies }\end{array}$ & $\begin{array}{l}\text { - Platform strategy succeeds when (i) multi-homing costs } \\
\text { are high, (ii) network effects are positive and strong, (iii) } \\
\text { sides don't have preference for special features } \\
\text { (Eisenmann et al., 2006) } \\
\text { - Pre-existing relationships with prospective users, } \\
\text { reputation for past prowess, and deep pockets help win } \\
\text { markets (Eisenmann et al., 2006) } \\
\text { - Enable open, participative infrastructure for the } \\
\text { interactions between external producers and consumers, } \\
\text { and set governance conditions for them (Parker et al., } \\
\text { 2016, p.5) } \\
\text { Emphasize ecosystem governance more than product } \\
\text { optimization; persuade outside partners more than } \\
\text { control of internal employees (Parker et al., 2016, p.12) }\end{array}$ \\
\hline Challenges & $\begin{array}{l}\text { - Threat of envelopment: platforms have to be vigilant, and } \\
\text { may have to change the business model, or find support } \\
\text { (Eisenmann et al., 2006) } \\
\text { - 'Managing platforms is tricky: strategies that make } \\
\text { traditional offerings successful won't work in the two- } \\
\text { sided markets (Eisenmann et al., 2006) } \\
\text { - When the participation of a few large users is crucial for } \\
\text { mobilizing a network, conflict over the division of value } \\
\text { between platform providers and large users is common } \\
\text { (Eisenmann et al., 2006) }\end{array}$ \\
\hline Critique & $\begin{array}{l}\text { - Failures rooted in creating strategies for two-sided } \\
\text { networks, relying on assumptions and paradigms that } \\
\text { apply to products without network effects. (Eisenmann et } \\
\text { al., 2006) }\end{array}$ \\
\hline
\end{tabular}




\subsection{The databases where MSP company data were found}

The purpose of this section is to provide information about databases that host information about companies that included MSP startups, and other useful websites where latest and most appreciated MSP startup companies could be found. Table 2.4 shows the aspects sought for and the resources that provided information related to those aspects and the respective website addresses.

Two online databases were used, namely "Crunchbase" and "Owler" to collect common data about MSP company profiles. CrunchBase data is updated in real time by a community of partners, machine learning, with the help of their data science team, and provide company information from early-stage startups to Fortune 1000 (www.crunchbase.com). Owler database is updated in real time from a community of business professionals and puts in information from small startups to large, global enterprises (www.owler.com)

Table 2.4 the aspects that were searched about and the sources of information

\begin{tabular}{|l|l|}
\hline Aspects & Source \\
\hline Founding year, and were headquartered in: & www.crunchbase.com \\
Status and the industry Sector: & www.owler.com \\
Funding information, status, Investors information: & \\
Founder (and CEO), and the leadership team: & \\
Estimated number of employees, employee history: & \\
Acquisitions made by the company: & \\
Website address, email and phone number: & \\
Social media links: & \\
News and activities: & \\
\hline
\end{tabular}




\begin{tabular}{|l|l|}
\hline $\begin{array}{l}\text { profile snapshot: } \\
\text { website traffic: }\end{array}$ & www.crunchbase.com \\
board members and advisors: & \\
\hline $\begin{array}{l}\text { Estimated revenue (TTM) and revenue history: } \\
\text { Website history snapshots and company history: }\end{array}$ & www.owler.com \\
\begin{tabular}{l} 
Competitive companies: \\
\hline $\begin{array}{l}\text { Provides business news with financial, media, tech, } \\
\text { and other industry verticals, including small } \\
\text { business news and trends according to VC investors }\end{array}$
\end{tabular} & www.businessinsider.com \\
\hline $\begin{array}{l}\text { Provides news, events, research, and perspective } \\
\text { on technology innovation covering small business } \\
\text { to enterprise, including a list of companies to watch } \\
\text { in a respective year. }\end{array}$ & www.venturebeat.com \\
\hline $\begin{array}{l}\text { Venture for Canada foster entrepreneurship, a } \\
\text { nonprofit that supports recent graduates to work at } \\
\text { Canadian startups. The list of startups provided on } \\
\text { the website covers Canadian startups in Nova } \\
\text { Scotia, New Brunswick, and Ontario. }\end{array}$ & www.ventureforcanada.com \\
\hline $\begin{array}{l}\text { Bloomberg provides private company information } \\
\text { including the legal name of the company, a brief } \\
\text { profile description, contact information and the } \\
\text { names of the key executives. }\end{array}$ & www.bloomberg.com \\
\hline
\end{tabular}

\subsection{The lessons learned}

Intermediaries may choose which mode to operate and mitigate the trade-offs

resulting from their decision to choose. While Hagiu and Wright (2015a; 2015b;

2015c) explain the decisions and the consequences of doing business in either

mode and specifically what an intermediary preferably be doing to operate an MSP.

By providing a specific definition of an MSP (Hagiu and Wright, 2015b, p.163), and 
precisely defining the terms "direct interaction" and "affiliation" the mathematical formulations explain the logic of an MSP to a greater extent. However, it does not explain what happens in a startup company's growth situation.

Hagiu (2006) distinguishes a proprietary platform against an open platform, and Hagiu (2007) identifies through mathematical explanation, two polar strategies: a "merchant mode", and a "two-sided platform mode". These findings have probably provided a foundation to exploit intermediary's choice of operation in an MSP mode.

Terminology has taken many variations in naming the mode of operation. "Proprietary platform and open platform" (Hagiu, 2004; 2006), "merchant mode and two-sided platform mode" (Hagiu, 2007), "reseller and marketplace" also indicating marketplace as a subsystem of MSP (Hagiu and Wright, 2015a), to defining a MSP (Hagiu and Wright, 2015b, p.163). The difference between a reseller, input supplier, a vertically integrated firm and an MSP, provides a fundamental understanding to learn and explore MSPs.

The literature based on empirical studies as well as the descriptive writings demonstrate the struggle to define an MSP (Eisenmann et al., 2006; Evans, 2016). Solving a "chicken-and-egg" problem was a major concern (Eisenmann et al., 2006; Hagiu, 2014; Evans, 2016; Evans and Schmalensee, 2016). The effect of market power (Hagiu, 2007), mitigating the risk of unfavourable expectations (Hagiu and Wright, 2015a; 2015b), and mitigating moral hazard problem (Hagiu and Wright, 2015c) somewhat implies the mechanisms of getting sides on board. 
Explanations of "control rights", "transferable decisions", "information advantage" and "marketing activities" (Hagiu and Wright, 2015a; 2015b; 2015c) help to understand some of the concerns and critiques presented in the empirical case-related literature (Evans and Schmalensee, 2016; Hagiu, 2014; Parker et al., 2016), and the descriptive writings (Eisenmann et al., 2006, Evans, 2016).

Network effects have been another major discussion which Hagiu and Wright (2015b) qualifies as a necessary but not sufficient requirement in an MSP mode. However, Hagiu and Wright (2015b) accept that MSPs create and capture value through indirect network effects.

Pricing strategies based on network externalities (Hagiu, 2004; 2014; Eisenmann et al., 2006; Evans, 2016; Evans and Schmalensee, 2016), were given an additional perspective of the importance of the control over interaction with non-price governance rules (Hagiu and Baudreau, 2008). This extends to Wang and Nicolau (2017) price determinants in a sharing economy that allows platforms charge premium prices against perceived quality signals.

Although pricing strategies, governance, and challenges were discussed broadly in the extant literature, less about an MSP logic relating to startup was discussed. The features explained through mathematical formations by Hagiu and Wright (2015a; 2015b, 2015c) found to be effective in creating a knowledge base to study important features around an MSP logic.

Types and characteristics of products and services, as well as attributes of sellers (independent professionals) and buyers (customers) (Hagiu and Wright, 2015a; 
2015b; 2015c) help, identify the responsibilities of an MSP operator, and to define the two sides and what to trade.

\subsection{Summary of the literature review}

The purpose of the review was to identify from the extant literature of the helpful hints of an MSP logic. As such, three articles based on the mathematical formulation of an MSP logic were chosen to identify elements for investigation:

1. A choice between functioning as a marketplace (MSP) or as a reseller, to optimally position themselves between the two modes with the best product/service decision in either of them (Hagiu and Wright, 2015a),

2. Trade-offs exist when choosing to operate as a marketplace (MSP) or reseller, that drive them towards or away from MSP model relative to traditional alternatives - VI firm, reseller, or input supplier (Hagiu and Wright, 2015b),

3. A choice between an employment mode (firm controls service provision by employing professionals, sales reps, and agents), and a platform mode (agents control the provision of their services to customers) (Hagiu and Wright, 2015c)

Hagiu and Altman (2017) presentation on MSP strategies was chosen to complement the above three presentations, and the corpus for review consisted four articles.

Research on sources to obtain empirical data on MSP companies found two useful databases of valuable information as shown in table 2.4. Except for few elements, both databases matched the information providing a strong foundation 
to record information on the companies selected to study. Further search for sources to find the names of new companies based on business news and trend reports resulted in three more websites as sources of information about MSP startup companies. 


\section{METHOD}

Chapter three is organized into five sections. Section 3.1 introduces the theoretical approach and the method the research was conducted. Section 3.2 describes the logic in corpus. Section 3.3 informs the research design and section 3.4 describes the data acquisition for research. Section 3.5 shows the data analysis method and section 3.6 concludes.

\subsection{Theoretical approach}

The review of the literature on MSP logic identified the need to concentrate on the selected corpus to study what interactions happen in formulating an MSP. As such three articles were selected for an in-depth study of the concepts, elements and the relationship between those elements. The three main articles were Hagiu and Wright (2015a), (2015b), and (2015c). These articles were related to previous work carried out by Hagiu, A., by himself and with other authors, finally coming up with formal mathematical modeling in an attempt to explain the assumptions woven around MSP logic. In addition to these three articles, the latest literature found by mid-2017, an article explaining strategic applications of MSP mode (Hagiu and Altman, 2017) was included in the corpus. The representation from the corpus led the first set of propositions that explained the concepts and relationships, and the elements and relationships exhibited in the representation were used to examine a sample of 19 companies. The method used to conduct research is shown in table 3.1. 
Table 3.1 Method the research was conducted

\begin{tabular}{|c|c|c|}
\hline & Activity & Outcome \\
\hline 1 & $\begin{array}{l}\text { Reviewed literature on MSP to } \\
\text { understand the concept, the logic of } \\
\text { an MSP to identify how a MSP startup } \\
\text { can grow from the inception }\end{array}$ & $\begin{array}{l}\text { Identified the need to focus on a } \\
\text { model to explain the logic of } \\
\text { MSPs and its strategic } \\
\text { implications }\end{array}$ \\
\hline 2 & $\begin{array}{l}\text { Analysed Economist view of MSPs to } \\
\text { find out concepts and positioning of } \\
\text { MSP among other traditional modes }\end{array}$ & $\begin{array}{l}\text { Decided on corpus from which to } \\
\text { build the initial model }\end{array}$ \\
\hline 3 & $\begin{array}{l}\text { Identified the elements and their } \\
\text { relationships acting in MSPs, and } \\
\text { developed logic to construct a model } \\
\text { from corpus }\end{array}$ & $\begin{array}{l}\text { Model that explain the elements } \\
\text { of an MSP, and affiliations } \\
\text { between those elements and a } \\
\text { set of propositions anchored } \\
\text { around the model }\end{array}$ \\
\hline 4 & $\begin{array}{l}\text { Developed criteria for sample } \\
\text { selection }\end{array}$ & $\begin{array}{l}\text { List of criteria for sample } \\
\text { selection }\end{array}$ \\
\hline 5 & $\begin{array}{l}\text { Examined the sample to gather data } \\
\text { that correspond to elements in the } \\
\text { model and that explain relationships } \\
\text { between them }\end{array}$ & $\begin{array}{l}\text { (i)a set of data that corresponds } \\
\text { to elements and their } \\
\text { relationships in the model; } \\
\text { (ii)a set of data that correspond } \\
\text { to new elements prompting } \\
\text { inequalities and differentiators } \\
\text { and a set of new relationships }\end{array}$ \\
\hline 6 & $\begin{array}{l}\text { Mapped characteristics of new } \\
\text { relationships and assigned entities }\end{array}$ & $\begin{array}{l}\text { A new set of entities that explain } \\
\text { new relationships representing } \\
\text { elements }\end{array}$ \\
\hline 5 & $\begin{array}{l}\text { Incorporated new entities and their } \\
\text { relationships in the initial model }\end{array}$ & $\begin{array}{l}\text { Refined model representing data } \\
\text { from corpus and new data } \\
\text { gathered }\end{array}$ \\
\hline 6 & $\begin{array}{l}\text { Developed propositions anchored } \\
\text { around the model }\end{array}$ & $\begin{array}{l}\text { A new set of propositions } \\
\text { anchored around findings that } \\
\text { represent newly found entities } \\
\text { and relationships }\end{array}$ \\
\hline
\end{tabular}




\subsection{Logic in corpus}

The representation from the corpus is shown in Figure 3.1. The information from corpus presents the direct interaction between two agents (independents and customers) affiliated with a third agent, MSP operator (Hagiu and Wright 2015a, p.184; 2015b, p.163; Hagiu and Altman 2017, p.96). The independents were assumed to have private information about the ideal choice of marketing activities (Hagiu and Wright, 2015a, p. 186,189; 2015b.p.170) and generate demand Hagiu and Wright, 2015a, p.186; 2015b, p.162). Customers make their affiliation and purchase decision (Hagiu and Wright, 2015b, p.166).

MSP operator fulfills responsibilities including selecting right products (Hagiu and Wright, 2015a, p.198, 196; 2015b, p.171; 2015c, p.3), and developing relationships with independents (Hagiu and Wright, 2015a, p.186; Hagiu and Altman, 2017, p.96,97). MSP operators assumed to have feedback systems in place (Hagiu and Wright, 2015b, p.171), and develop leadership roles in marketing and business management areas (Hagiu and Altman, 2017, p.100).

Both sides affiliate with the platform by making platform-specific investments (Hagiu and Wright, 2015b, p.163). 
Figure 3. 1 Representation from corpus showing key elements and relationships

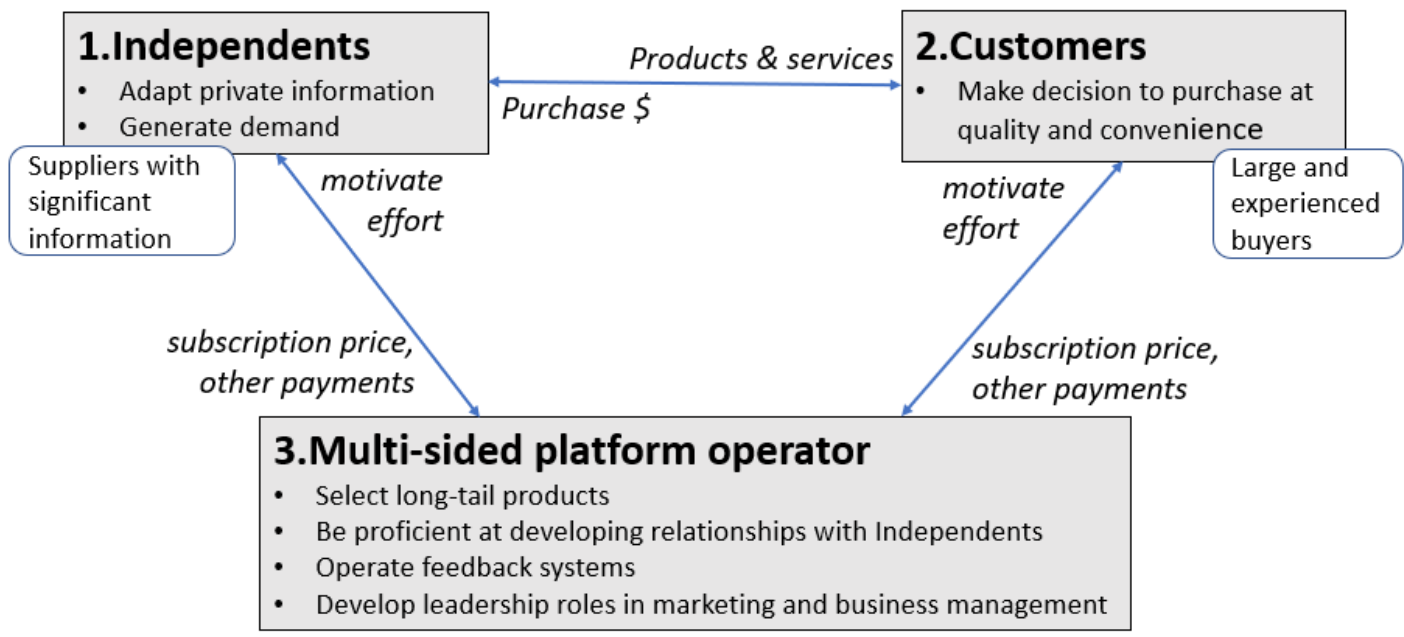

\subsection{Research design}

- Unit of analysis: a post-funding stage MSP startup operational in 2017

- Time period: $2012-2017$

- Sample: nineteen companies deliberately chosen for most relevant data.

The sample chosen on the purpose of the study was drawn from online data and included in both databases www.crunchbase.com and www.owler.com.

\subsection{Data acquisition}

Foundational data were acquired as reported in the two online databases:

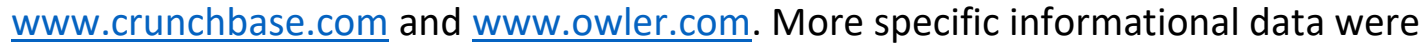
sought in the websites of the selected companies. Foundational data included the funding details, estimated annual revenue, founding year and the city and country 
where the company was headquartered. Informational data included the information about agents: independents, customers, and the MSP operator, their affiliations, and related platform-specific investments. Any inequalities and differentiators to the above-sighted data were also recorded as a part of data acquisition from company websites.

\subsection{Data analysis}

Data analysis was based on Object Oriented Analysis (OOA) to the level of object modeling. This means developing a static structure of the system in terms of objects. It defines the objects, the classes into which objects can be grouped, and the relationships. As such MSP companies were analyzed to identify elements, and assign the elements to entities, namely, independents, customers and the operator, and draw relationships among entities. Further, elements that were identified based on data gathered related to inequalities and differentiators, were assigned to new entities. Subsequently, relationships were drawn to specify affiliations between entities, and main attributes and operations of all entities were identified. Figure 3.2 shows the steps carried out in the data analyses. 
Figure 3. 2 Representation of data analyses based on Object-Oriented Analysis technique

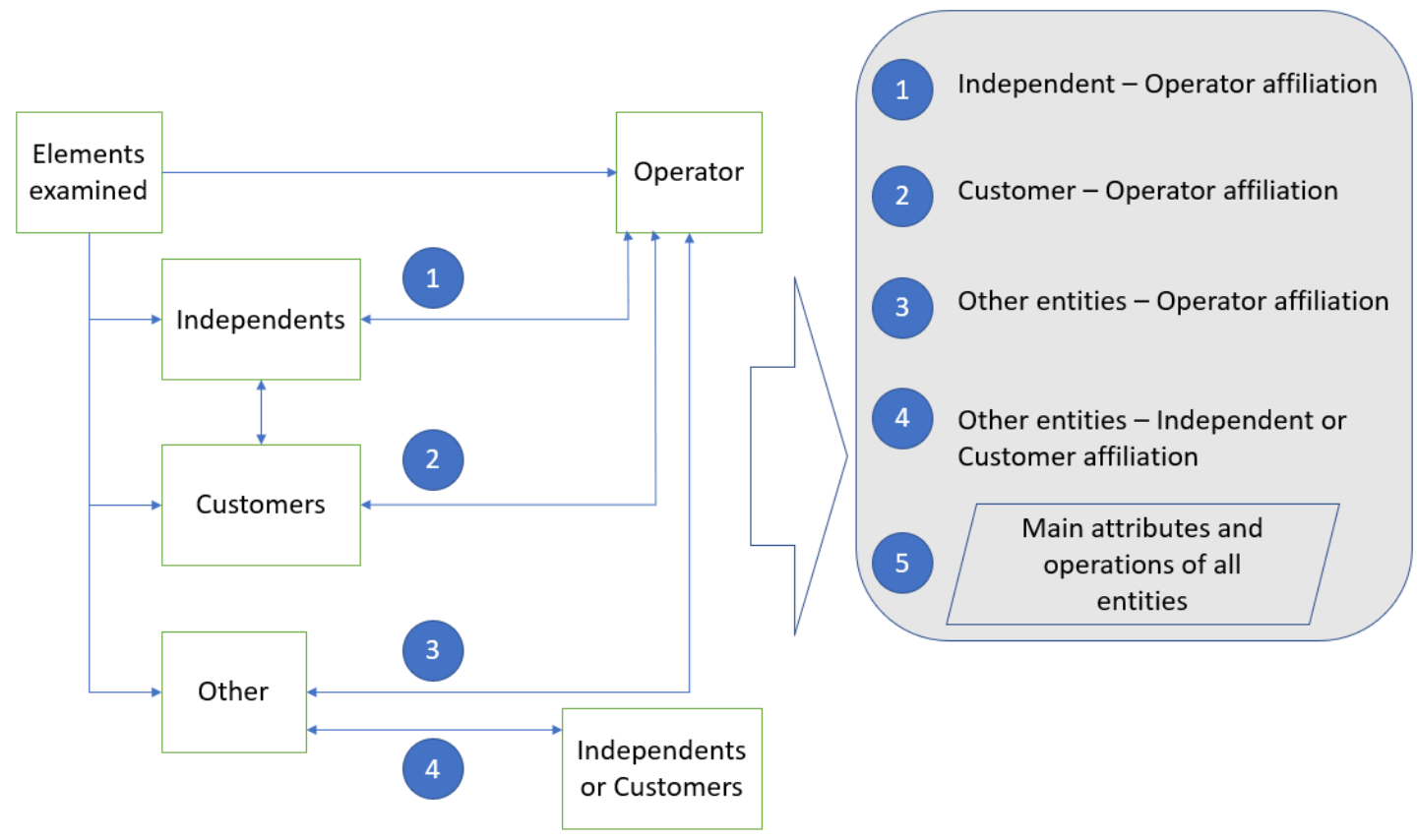

The operational measures for the theoretical constructs were based on the logic in corpus: independents, customers, and MSP operator and the affiliations among them. Data collection procedure maintained a chain of evidence (Yin, 2018) to make it explicit as possible to establish reliability of the operation of the study. Indicator data were tabulated as evidentiary base and provided in appendices in the thesis document.

Of the data gathered, the data corresponding to inequalities and differentiators with respect to logic in corpus were recorded, their relationships to main entities (independents, customers, and MSP operator) and responsibilities were identified and assigned as new elements. These elements were analysed and grouped into four entities which were then labeled as new agents. 
Appendix 3 shows the recorded evidentiary data for 19 companies included in the sample and the assignment of elements, grouping of the entities, their relationships, and the labeling of the four entities.

\subsection{Summary}

Chapter 3 presented the method in which the research was conducted. It identified the theoretical approach, conceptual model which based the research, and provided a representation of the model from the corpus. Chapter described how the data were acquired, how data were analyzed, and the technique used with a representation of the application of the data analysis technique. The reliability of the study and the traceability of evidence were presented. 


\section{RESULTS}

Chapter 4 is organized into seven sections. Section 4.1 describes the sample. Section 4.2 provides a model that captures the logic of the MSP provided in Hagiu and Wright (2015a; 2015b; 2015c) and applications to specific strategies provided in Hagiu and Altman (2017). Section 4.3 presents propositions anchored around the model. Section 4.4 identifies the new agents found from examining the data on MSPs. A revised representation, one drawn from corpus and data on MSP companies, is described in section 4.5, and new propositions are provided in section 4.6. Section 4.7 is a summary of the chapter.

\subsection{Sample}

The sample includes 19 MSP companies. Each company met the following criteria for inclusion:

1. Founded between 2012 and 2017, and operational as of November 2017

2. Profile (including funding, and status) included in both databases:

https://www.crunchbase.com/ and https://www.owler.com/

3. Raised more than $\$ 1$ million, and not acquired by another business as indicated in the Crunchbase and Owler databases

4. Reported expected annual revenue of $\$ 1$ Million or more as indicated in https://www.owler.com/

5. Provided examinable information regarding interaction and affiliations between sides in the company website 


\subsubsection{Sample selection process}

Figure 4.1 shows the sample selection process and the sources used to identify the sample. MSPs serve multiple groups or facilitate interactions between customers or groups (Hagiu and Altman, 2017). Names of MSP companies were found in Parker et al. (2016), Business Insider (www.businessinsider.com), Venture for Canada (www.ventureforcanada.com), Venture Beat (www.venturebeat.com), Crunchbase (www.crunchbase.com), and Owler (www.owler.com). These companies were examined for selection criteria using the company details provided in the two databases Crunchbase, and Owler. Once a company meets criteria next step was to check whether sufficient information was available on the company website to gather data with respect to inspected elements. If sufficient information were not available, that company was removed from the list. Of the total of 124 companies examined, 19 companies that met sample criteria were selected to represent founding years from 2012-2017. 
Figure 4. 1 Sample selection process satisfying five criteria and the sources where companies were drawn from

Names of MSP companies found in,

- Parker et al. (2016)

- Business Insider (www.businessinsider.com

- Venture Beat www.venturebeat.com

- Venture for Canada www.ventureforcanada.com

Names of MSP companies found in,

- Crunch base (www.crunchbase.com)

- Owler (www.owler.com)
- Profiles available in both data bases www.crunchbase.com and www.owler.com

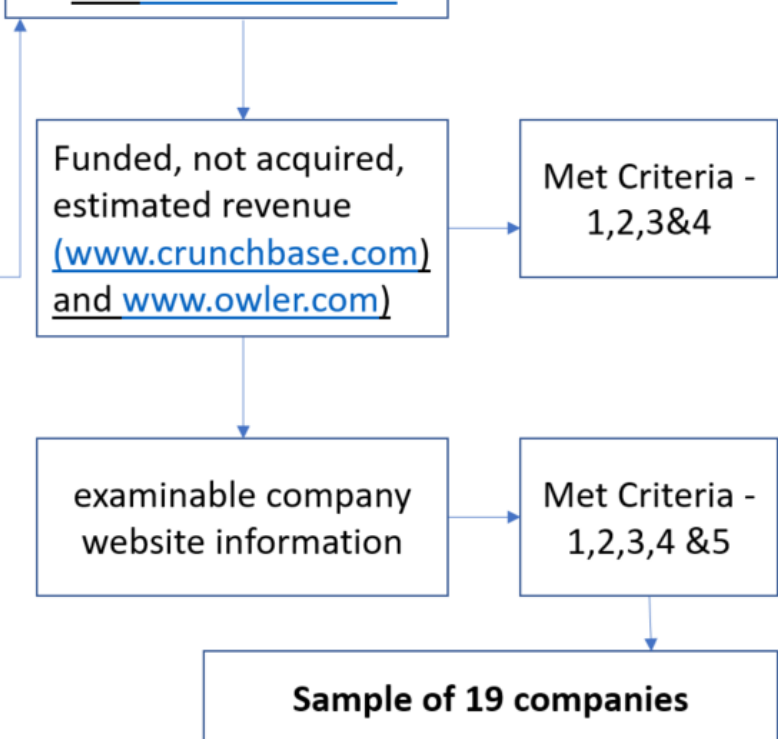

\subsubsection{Sample related information}

For each of the 19 MSP companies in the sample, Table 4.1 provides the company's name, web address, and founding year, a brief description of the transaction the MSP enables and estimated revenue. The estimated revenue refers to the trailing twelve months (TTM) revenue as reported by https://www.owler.com/. Some companies had names that were different to the name it is known about (ex: Instacat company name is Maplebear, Inc., but they call it Instacart). The corresponding corporate names of the companies are stated as found in the www.bloomberg.com. 
Table 4. 1 Companies launched and grown as multi-sided platforms between 2012-2017 included in the sample

\begin{tabular}{|c|c|c|c|c|}
\hline & $\begin{array}{l}\text { Company's name, "alias", and } \\
\text { web address }\end{array}$ & $\begin{array}{l}\text { Year } \\
\text { founded }\end{array}$ & $\begin{array}{l}\text { Transaction the MSP } \\
\text { enables }\end{array}$ & $\begin{array}{l}\text { Estimated } \\
\text { revenue }\end{array}$ \\
\hline 1. & $\begin{array}{l}\text { Maplebear, Inc. | } \\
\text { “Instacart"www.instacart.com }\end{array}$ & 2012 & $\begin{array}{l}\text { Grocers sell } \\
\text { groceries with a } \\
\text { delivery service } \\
\text { option to consumers }\end{array}$ & $\$ 67.7 \mathrm{M}$ \\
\hline 2. & $\begin{array}{l}\text { Tradeos, Ltd. I "Freightos" } \\
\text { www.freightos.com }\end{array}$ & 2012 & $\begin{array}{l}\text { Shippers and } \\
\text { forwarders/carriers } \\
\text { generate quotes, } \\
\text { share rates, and find } \\
\text { lowest shipping } \\
\text { rates and fastest } \\
\text { routes for customers }\end{array}$ & $\$ 5.8 \mathrm{M}$ \\
\hline 3. & $\begin{array}{l}\text { Coursera, Inc. I "Coursera" } \\
\text { www.coursera.org }\end{array}$ & 2012 & $\begin{array}{l}\text { Course providers/ } \\
\text { Developers offer } \\
\text { courses to learners }\end{array}$ & $\$ 19.7 M$ \\
\hline 4. & $\begin{array}{l}\text { Cohealo Inc. I "Cohealo" } \\
\text { http://cohealo.com }\end{array}$ & 2012 & $\begin{array}{l}\text { Health } \\
\text { systems/Institutions } \\
\text { centralize clinical } \\
\text { assets and improve } \\
\text { access to care for } \\
\text { medical facilities and } \\
\text { clinicians }\end{array}$ & $\$ 3.6 \mathrm{M}$ \\
\hline 5. & $\begin{array}{l}\text { MLW Squared, Inc. I } \\
\text { "Ahalogy" www.ahalogy.com }\end{array}$ & 2012 & $\begin{array}{l}\text { Brands and content } \\
\text { creators uncover } \\
\text { audience insights to } \\
\text { deliver optimum } \\
\text { engagement to } \\
\text { consumers }\end{array}$ & $\$ 2.9 \mathrm{M}$ \\
\hline 6. & $\begin{array}{l}\text { Exitround, LLC | "Exitround" } \\
\text { www.exitround.com }\end{array}$ & 2013 & $\begin{array}{l}\text { Company founders } \\
\text { feature best } \\
\text { company exposure } \\
\text { and buyers acquire } \\
\text { companies }\end{array}$ & $\$ 1 M$ \\
\hline
\end{tabular}




\begin{tabular}{|c|c|c|c|c|}
\hline 7. & $\begin{array}{l}\text { DoorDash, Inc. I "DoorDash" } \\
\text { www.doordash.com }\end{array}$ & 2013 & $\begin{array}{l}\text { Businesses sell food } \\
\text { and other items and } \\
\text { customers buy and } \\
\text { order delivery }\end{array}$ & $\$ 4 M$ \\
\hline 8. & $\begin{array}{l}\text { FarmLead Resources Ltd. I } \\
\text { “Farmlead" } \\
\underline{\text { https://farmlead.com }}\end{array}$ & 2013 & $\begin{array}{l}\text { Farmers and verified } \\
\text { buyers list, negotiate } \\
\text { and finalize grain } \\
\text { deals }\end{array}$ & $\$ 3.4 \mathrm{M}$ \\
\hline 9. & $\begin{array}{l}\text { Guesty, Inc. I "Guesty" } \\
\text { www.guesty.com }\end{array}$ & 2013 & $\begin{array}{l}\text { Property } \\
\text { management hosts, } \\
\text { Airbnb hosts with } \\
\text { multiple accounts } \\
\text { provide and manage } \\
\text { services to guests }\end{array}$ & $\$ 1 M$ \\
\hline 10. & $\begin{array}{l}\text { Pillow Homes, Inc. I "Pillow" } \\
\text { www.pillowhomes.com }\end{array}$ & 2014 & $\begin{array}{l}\text { Building owners } \\
\text { allow compliant and } \\
\text { transparent process } \\
\text { for residents to host } \\
\text { their apartment on } \\
\text { short term rentals }\end{array}$ & $\$ 2 M$ \\
\hline 11. & $\begin{array}{l}\text { Helpling GmbH | "Helpling" } \\
\text { www.helpling.de }\end{array}$ & 2014 & $\begin{array}{l}\text { Cleaning aids offer } \\
\text { household services } \\
\text { and customers } \\
\text { search and book } \\
\text { cleaning aids on- } \\
\text { demand online }\end{array}$ & $\$ 19 M$ \\
\hline 12. & $\begin{array}{l}\text { Thrive Market, Inc. I "Thrive } \\
\text { Market" } \\
\text { www.thrivemarket.com }\end{array}$ & 2014 & $\begin{array}{l}\text { Brands sell healthy } \\
\text { foods and natural } \\
\text { products at } \\
\text { wholesale prices to } \\
\text { members }\end{array}$ & $\$ 1.3 \mathrm{M}$ \\
\hline 13. & $\begin{array}{l}\text { Loop Financial, Inc. | "Lending } \\
\text { Loop" www.lendingloop.ca }\end{array}$ & 2014 & $\begin{array}{l}\text { Small businesses } \\
\text { find affordable } \\
\text { financing at fair } \\
\text { interest rates from } \\
\text { lenders }\end{array}$ & $\$ 1.5 \mathrm{M}$ \\
\hline
\end{tabular}




\begin{tabular}{|c|c|c|c|c|}
\hline 14. & $\begin{array}{l}\text { Proov, Inc. I "prooV" } \\
\text { www.proov.io }\end{array}$ & 2015 & $\begin{array}{l}\text { Startups allow } \\
\text { enterprises to test, } \\
\text { track and analyze } \\
\text { their solutions and } \\
\text { enterprises carry out } \\
\text { proof of concept }\end{array}$ & $\$ 4 M$ \\
\hline 15. & $\begin{array}{l}\text { Outschool, Inc | "Outschool" } \\
\underline{\text { https://outschool.com }}\end{array}$ & 2015 & $\begin{array}{l}\text { Teachers offer and } \\
\text { sell virtual classes } \\
\text { and parents find, } \\
\text { book and pay for } \\
\text { children's classes }\end{array}$ & $\$ 2 M$ \\
\hline 16. & $\begin{array}{l}\text { Airsorted Limited | "Airsorted" } \\
\text { www.airsorted.uk }\end{array}$ & 2015 & $\begin{array}{l}\text { Homeowners let } \\
\text { their homes to } \\
\text { guests without being } \\
\text { a host }\end{array}$ & $\$ 1 M$ \\
\hline 17. & $\begin{array}{l}\text { Mealpal, Inc. I "MealPal” } \\
\text { www.mealpal.com }\end{array}$ & 2016 & $\begin{array}{l}\text { Restaurants offer } \\
\text { monthly } \\
\text { subscription meal } \\
\text { plans to members }\end{array}$ & $\$ 5 M$ \\
\hline 18. & $\begin{array}{l}\text { MissionU PBC I "MissionU” } \\
\underline{\text { www.missionu.com }}\end{array}$ & 2016 & $\begin{array}{l}\text { Instructors and } \\
\text { industry experts } \\
\text { facilitate industry } \\
\text { informed } \\
\text { curriculum-based } \\
\text { learning to students } \\
\text { through live sessions }\end{array}$ & $\$ 1 M$ \\
\hline 19. & $\begin{array}{l}\text { Snappr Pty. Ltd. I "Snappr" } \\
\underline{\text { www.snappr.co }}\end{array}$ & 2016 & $\begin{array}{l}\text { Photographers offer } \\
\text { onsite services and } \\
\text { customers book pre- } \\
\text { vetted on demand } \\
\text { photographers }\end{array}$ & $\$ 1 M$ \\
\hline
\end{tabular}

Sources: https://www.crunchbase.com/, https://www.owler.com/, https://www.bloomberg.com and company websites

Table 4.2 identifies the locations where the companies in the sample are headquartered as of 2017 and information on funds raised. For each company in 
the sample, Table 4.2 provides the city, state/province/region, and country where the company is headquartered as well as the number of dollars raised, amount raised at the most recent round, funding type, and funding status.

The funding types shown in Table 4.2 include Seed, Series A, B, C, and D, Convertible note, and Debt Financing. Typically, seed funds are directed toward product development, market research, building a management team and preparing a business plan (www.investopedia.com).

Series A and B refer to early-stage funding. Series A refers to the first round of external funds, and Series B refers to the second round of external funds. Series C and D funding are used to ramp up operations (www.entepreneur.com). A convertible note is a form of short-term debt that converts into equity, in a future financing round (www.seedinvest.com). Debt financing refers to raising money for working capital by selling bonds, bills, or notes to investors on the promise that principal and interest on the debt will be repaid (www.investopedia.com).

Funding status shown in Table 4.2, includes Seed, Early Stage Venture (ESV), and Late Stage Venture. Seed is the first stage of venture capital funding. Early Stage Venture (ESV) is a second stage and funds a step up in capabilities and initiates commercial manufacturing and sales. Most companies in this stage have a product or service in testing or pilot production. Late Stage Venture (LSV) funding is provided when a company shows a significant revenue growth, but may not be showing profits (www.investopedia.com). 
Table 4. 2 Companies included in the sample by location of headquarters and information on funds raised

\begin{tabular}{|c|c|c|c|c|c|}
\hline $\begin{array}{l}\text { Company's name | } \\
\text { "alias" and web } \\
\text { address }\end{array}$ & $\begin{array}{l}\text { Headquartered } \\
\text { in }\end{array}$ & $\begin{array}{l}\text { Amount } \\
\text { raised }\end{array}$ & $\begin{array}{l}\text { Latest } \\
\text { funding }\end{array}$ & $\begin{array}{l}\text { Latest } \\
\text { funding } \\
\text { type }\end{array}$ & $\begin{array}{l}\text { Funding } \\
\text { status }\end{array}$ \\
\hline $\begin{array}{l}\text { Maplebear, Inc. I } \\
\text { "Instacart" } \\
\text { www.instacart.com }\end{array}$ & $\begin{array}{l}\text { SanFrancisco, } \\
\text { California, } \\
\text { United States }\end{array}$ & $\begin{array}{l}\$ 674.8 \mathrm{M} \\
\text { in } 7 \\
\text { rounds }\end{array}$ & $\begin{array}{l}\$ 400 M / \\
\text { Mar } 2017\end{array}$ & $\begin{array}{l}\text { Series } \\
\text { D }\end{array}$ & $\begin{array}{l}\text { Late } \\
\text { Stage } \\
\text { Venture }\end{array}$ \\
\hline $\begin{array}{l}\text { Tradeos, Ltd. I } \\
\text { "Freightos" } \\
\text { www.freightos.co } \\
\underline{\mathrm{m}}\end{array}$ & $\begin{array}{l}\text { Mong Kok, Hong } \\
\text { Kong }\end{array}$ & $\begin{array}{l}\$ 55.9 \mathrm{M} \\
\text { in } 6 \\
\text { rounds }\end{array}$ & $\begin{array}{l}\$ 25 \mathrm{M} / \\
\text { Mar } 2017\end{array}$ & Series B & $\begin{array}{l}\text { Early } \\
\text { Stage } \\
\text { Venture }\end{array}$ \\
\hline $\begin{array}{l}\text { Coursera, Inc. I } \\
\text { "Coursera" } \\
\text { www.coursera.org } \\
\end{array}$ & $\begin{array}{l}\text { MountainView, } \\
\text { California, } \\
\text { United States }\end{array}$ & $\begin{array}{l}\$ 210.1 \mathrm{M} \\
\text { in } 7 \\
\text { rounds }\end{array}$ & $\begin{array}{l}\$ 64 M / \\
\text { Jun } 2017\end{array}$ & $\begin{array}{l}\text { Series } \\
\text { D }\end{array}$ & $\begin{array}{l}\text { Late } \\
\text { Stage } \\
\text { Venture }\end{array}$ \\
\hline $\begin{array}{l}\text { Cohealo Inc. I } \\
\text { "Cohealo" } \\
\text { http://cohealo.co } \\
\underline{\mathrm{m}}\end{array}$ & $\begin{array}{l}\text { Boston, Massac } \\
\text { husetts, United } \\
\text { States }\end{array}$ & $\begin{array}{l}\$ 12.15 \mathrm{M} \\
\text { in } 3 \\
\text { rounds }\end{array}$ & $\begin{array}{l}\text { \$2M / } \\
\text { Sep } 2016\end{array}$ & Series A & $\begin{array}{l}\text { Early } \\
\text { Stage } \\
\text { Venture }\end{array}$ \\
\hline $\begin{array}{l}\text { MLW Squared, Inc. } \\
\text { I "Ahalogy" } \\
\text { www.ahalogy.com }\end{array}$ & $\begin{array}{l}\text { Cincinnati, Ohio, } \\
\text { United States }\end{array}$ & $\begin{array}{l}\$ 10.2 \mathrm{M} \\
\text { in } 4 \\
\text { rounds }\end{array}$ & $\begin{array}{l}\$ 3 M / \\
\text { Jul } 2016\end{array}$ & $\begin{array}{l}\text { Series } \\
\text { unkno } \\
\text { wn }\end{array}$ & $\begin{array}{l}\text { Status } \\
\text { unknown }\end{array}$ \\
\hline $\begin{array}{l}\text { Exitround, LLC I } \\
\text { "Exitround" } \\
\text { www.exitround.co } \\
\underline{\mathrm{m}}\end{array}$ & $\begin{array}{l}\text { San Francisco, } \\
\text { California, } \\
\text { United States }\end{array}$ & $\begin{array}{l}\$ 1.625 \mathrm{M} \\
\text { in } 2 \\
\text { rounds }\end{array}$ & $\begin{array}{l}\$ 1.63 M / \\
\text { Feb } 2015\end{array}$ & Seed & Seed \\
\hline $\begin{array}{l}\text { DoorDash, Inc. I } \\
\text { "DoorDash" } \\
\text { www.doordash.co } \\
\underline{\mathrm{m}}\end{array}$ & $\begin{array}{l}\text { San Francisco, } \\
\text { California, } \\
\text { United States }\end{array}$ & $\begin{array}{l}\$ 186.7 \mathrm{M} \\
\text { in } 5 \\
\text { rounds }\end{array}$ & $\begin{array}{l}\text { \$127M / } \\
\text { Mar } 2016\end{array}$ & Series C & $\begin{array}{l}\text { Late } \\
\text { Stage } \\
\text { Venture }\end{array}$ \\
\hline $\begin{array}{l}\text { FarmLead } \\
\text { Resources Ltd. I } \\
\text { "Farmlead" }\end{array}$ & $\begin{array}{l}\text { Ottawa, Ontario } \\
\text { Canada }\end{array}$ & $\begin{array}{l}\$ 7.28 \mathrm{M} \\
\text { in } 2 \\
\text { rounds }\end{array}$ & $\begin{array}{l}\$ 6.5 \mathrm{M} / \\
\text { Mar } 2017\end{array}$ & Series A & $\begin{array}{l}\text { Early } \\
\text { Stage } \\
\text { Venture }\end{array}$ \\
\hline
\end{tabular}




\begin{tabular}{|c|c|c|c|c|c|}
\hline $\begin{array}{l}\text { https://farmlead.c } \\
\underline{\text { om }}\end{array}$ & & & & & \\
\hline $\begin{array}{l}\text { Guesty, Inc. I } \\
\text { "Guesty" } \\
\text { www.guesty.com } \\
\end{array}$ & $\begin{array}{l}\text { San Francisco, } \\
\text { California, } \\
\text { United States }\end{array}$ & $\begin{array}{l}\$ 4.5 \mathrm{M} \text { in } \\
2 \text { rounds }\end{array}$ & $\begin{array}{l}\$ 3 M / \\
\text { May } 2017\end{array}$ & Series A & $\begin{array}{l}\text { Early } \\
\text { Stage } \\
\text { Venture }\end{array}$ \\
\hline $\begin{array}{l}\text { Pillow Homes, Inc. } \\
\text { " Pillow" } \\
\text { www.pillowhomes. } \\
\text { com }\end{array}$ & $\begin{array}{l}\text { San Francisco, } \\
\text { California, } \\
\text { United States }\end{array}$ & $\begin{array}{l}\$ 16.15 \mathrm{M} \\
\text { in } 3 \\
\text { rounds }\end{array}$ & $\begin{array}{l}\$ 13.5 \mathrm{M} / \\
\text { Jun } 2017\end{array}$ & Series A & $\begin{array}{l}\text { Early } \\
\text { Stage } \\
\text { Venture }\end{array}$ \\
\hline $\begin{array}{l}\text { Helpling GmbH | } \\
\text { “Helpling” } \\
\text { www.helpling.de } \\
\end{array}$ & $\begin{array}{l}\text { Berlin, Berlin, } \\
\text { Germany }\end{array}$ & $\begin{array}{l}\$ 72.74 \mathrm{M} \\
\text { in } 4 \\
\text { rounds }\end{array}$ & $\begin{array}{l}\$ 10 M / \\
\text { Mar } 2017\end{array}$ & Series C & $\begin{array}{l}\text { Status } \\
\text { unknown }\end{array}$ \\
\hline $\begin{array}{l}\text { Thrive Market, Inc. } \\
\text { I "Thrive Market" } \\
\text { www.thrivemarket. } \\
\text { com }\end{array}$ & $\begin{array}{l}\text { Los Angeles, } \\
\text { California, } \\
\text { United States }\end{array}$ & $\begin{array}{l}\$ 161.88 \\
M \text { in } 4 \\
\text { rounds }\end{array}$ & $\begin{array}{l}\$ 10 M / \\
\text { Oct } 2016\end{array}$ & $\begin{array}{l}\text { Convert } \\
\text { i-ble } \\
\text { note }\end{array}$ & $\begin{array}{l}\text { Early } \\
\text { Stage } \\
\text { Venture }\end{array}$ \\
\hline $\begin{array}{l}\text { Loop Financial, Inc. } \\
\text { I "Lending Loop" } \\
\text { www.lendingloop.c } \\
\underline{\text { a }}\end{array}$ & $\begin{array}{l}\text { Toronto, } \\
\text { Ontario, Canada }\end{array}$ & $\begin{array}{l}\$ 12 \mathrm{M} \text { in } \\
2 \text { rounds }\end{array}$ & $\begin{array}{l}\$ 10 M / \\
\text { Oct } 2017\end{array}$ & $\begin{array}{l}\text { Debt } \\
\text { financi } \\
\text { ng }\end{array}$ & $\begin{array}{l}\text { Status } \\
\text { unknown }\end{array}$ \\
\hline $\begin{array}{l}\text { Proov, Inc. I } \\
\text { "prooV" } \\
\text { www.proov.io } \\
\end{array}$ & $\begin{array}{l}\text { Herzlia B, Tel } \\
\text { Aviv, Israel }\end{array}$ & $\begin{array}{l}\$ 21 \mathrm{M} \text { in } \\
2 \text { rounds }\end{array}$ & $\begin{array}{l}\$ 14 M / \\
\text { Aug } 2017\end{array}$ & Series B & $\begin{array}{l}\text { Early } \\
\text { Stage } \\
\text { Venture }\end{array}$ \\
\hline $\begin{array}{l}\text { Outschool, Inc I } \\
\text { "Outschool" } \\
\text { https://outschool.c } \\
\underline{\text { om }}\end{array}$ & $\begin{array}{l}\text { San Francisco, } \\
\text { California, } \\
\text { United States }\end{array}$ & $\begin{array}{l}\$ 1.52 \mathrm{M} \\
\text { in } 2 \\
\text { rounds }\end{array}$ & $\begin{array}{l}\$ 1,4 M / \\
\text { Jun } 2017\end{array}$ & Seed & Seed \\
\hline $\begin{array}{l}\text { Airsorted Limited | } \\
\text { "Airsorted" } \\
\text { www.airsorted.uk } \\
\end{array}$ & $\begin{array}{l}\text { London, England } \\
\text { United Kingdom }\end{array}$ & $\begin{array}{l}\$ 1.88 \mathrm{M} \\
\text { in } 5 \\
\text { rounds }\end{array}$ & $\begin{array}{l}\$ 1.5 \mathrm{M} / \\
\text { Feb } 2017\end{array}$ & Seed & Seed \\
\hline $\begin{array}{l}\text { Mealpal, Inc. I } \\
\text { "MealPal" } \\
\text { www.mealpal.com } \\
\end{array}$ & $\begin{array}{l}\text { New City, New } \\
\text { York, United } \\
\text { States }\end{array}$ & $\begin{array}{l}\$ 35 \mathrm{M} \text { in } \\
2 \text { rounds }\end{array}$ & $\begin{array}{l}\text { \$20M / } \\
\text { Sep } 2017\end{array}$ & Series B & $\begin{array}{l}\text { Early } \\
\text { Stage } \\
\text { Venture }\end{array}$ \\
\hline
\end{tabular}




\begin{tabular}{|l|l|l|l|l|l|}
\hline $\begin{array}{l}\text { MissionU PBC I } \\
\text { "MissionU" } \\
\text { www.missionu.co } \\
\underline{\mathrm{m}}\end{array}$ & $\begin{array}{l}\text { San Francisco, } \\
\text { California, } \\
\text { United States }\end{array}$ & $\begin{array}{l}\text { \$11.5M } \\
\text { in 2 } \\
\text { rounds }\end{array}$ & $\begin{array}{l}\text { \$8.5 / } \\
\text { Sep 2017 }\end{array}$ & Series A & $\begin{array}{l}\text { Early } \\
\text { Stage } \\
\text { Venture }\end{array}$ \\
\hline $\begin{array}{l}\text { Snappr Pty. Ltd. I } \\
\text { "Snappr" } \\
\text { www.snappr.co }\end{array}$ & $\begin{array}{l}\text { San Francisco, } \\
\text { California, } \\
\text { United States }\end{array}$ & $\begin{array}{l}\text { \$2.38M } \\
\text { in 3 } \\
\text { rounds }\end{array}$ & $\begin{array}{l}\text { \$2M / } \\
\text { Sep 2017 }\end{array}$ & Seed & Seed \\
\hline
\end{tabular}

Table 4.3 identifies the six countries where the sample companies were headquartered. Of the 19 companies, included in the sample, 15 or $78.9 \%$ were headquartered in North America.

Table 4. 3 Breakdown of companies in sample by country

\begin{tabular}{|l|l|l|l|}
\hline & Country & $\begin{array}{l}\text { Number of companies in } \\
\text { sample }\end{array}$ & Proportion \\
\hline 1. & United States & 13 & $68.4 \%$ \\
\hline 2. & Canada & 2 & $10.5 \%$ \\
\hline 3. & Israel & 1 & $5.3 \%$ \\
\hline 4. & Hong Kong, China & 1 & $5.3 \%$ \\
\hline 5. & United Kingdom & 1 & $5.3 \%$ \\
\hline 6. & Germany & 1 & $5.3 \%$ \\
\hline & Total & 19 & $100 \%$ \\
\hline
\end{tabular}

Appendix 1 provides information on funding and estimated revenue $(\$ 1 \mathrm{M}$ or above) of each of the 19 companies included in the sample. 


\subsection{Representation drawn from selected corpus}

Figure 4.2 provides the researcher's representation of the logic of the MSP provided in Hagiu and Wright (2015a; 2015b; 2015c) and applications to specific strategies provided in Hagiu and Altman (2017).

Figure 4. 2 Representation of the logic of an MSP extracted from the selected corpus

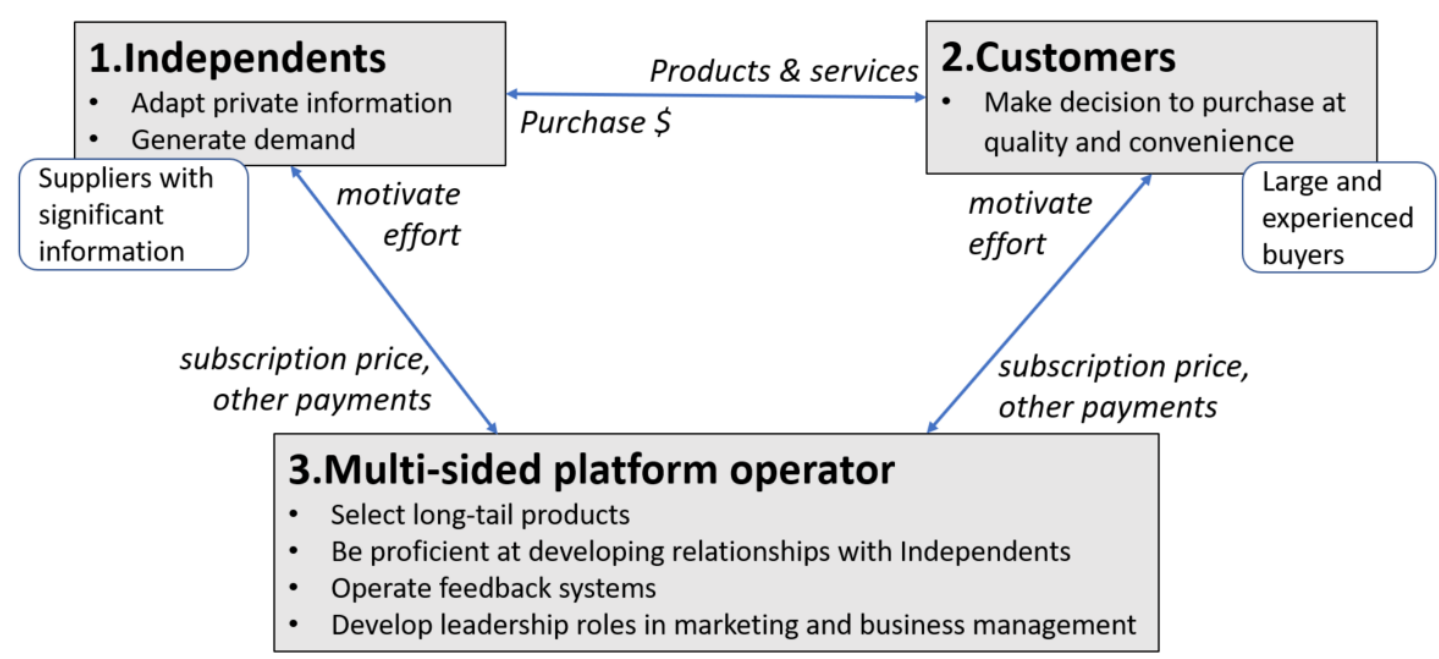

The model is comprised of three agents and three affiliations. The three agents include the MSP operator (Operator), independent suppliers (Independents), and customers (Customers). The operator makes platform-specific investments to enable direct interaction between independents and customers, and the independents and customers make platform-specific investments to be able to directly interact with each other (Hagiu and Wright, 2015b, p.163). 


\subsubsection{Agent 1: Independent}

Independents have two key responsibilities: adapt to private information (i.e., develop skills, modify offers) and generate demand for their services (Hagiu and Wright, 2015b, p.162, 165).

\subsubsection{Agent 2: Customer}

Customers have one key responsibility: deal with Independents directly without needing intermediaries to verify quality and convince them to buy (Hagiu and Wright, 2015b, p.163, 164).

\subsubsection{Agent 3: Operator}

The operator has four key responsibilities:

- Select long-tail products (i.e., long shelf-life products)

- Be proficient at developing relationships with independents

- Operate feedback systems to overcome asymmetric information problems

- Develop leadership roles in marketing and business development

Operators select long-tail products i.e., products have a low marginal cost of handling and can stay a long time on the shelves before they sell (Hagiu and Wright, 2015a. p.196). Operators develop proficient relationships with independents (Hagiu and Wright. 2015a, p.162,167; Hagiu and Altman, 2017, p.96). Operators need to 
develop the capability to curate these relationships to prevent conflicts among existing parties (Hagiu and Altman, 2017, p.97).

Operators use feedback systems to pool users' experience as a solution to overcome asymmetric information problems (Hagiu and Wright, 2015b, p.171). Success depends on incentives to users to share their experience and how feedback benefits the other users.

An MSP moves the operator from a product/service orientation to a relationship management orientation. The need to place relationships with people up-front requires operators to develop leadership roles in marketing and business development (Hagiu and Altman, 2017, p.97).

\subsubsection{Affiliation 1: Independent-Customer Affiliation}

The affiliation between the independent and the customer is specified in terms of the:

- Investment that customer makes to be able to purchase from independents (Hagiu and Wright, 2015b, p.165)

- Investment that independents make to raise the number of clients for the service they offer (Hagiu and Wright, 2015b, p.165)

\subsubsection{Affiliation 2: Independent-Operator Affiliation}

The affiliation between the independent and the operator is specified in terms of the: 
- Investment that independent makes in the operator's platform including the subscription price or other payments to directly interact with customers (Hagiu and Wright, 2015b, p.163, 164)

- Investment that operator makes to motivate the independent's efforts and ensure that independents adapt their decisions to their private information (Hagiu and Wright, 2015b, p.162)

\subsubsection{Affiliation 3: Customer-Operator Affiliation}

The affiliation between the customer and the operator is specified in terms of the:

- Investment that customer makes in the operator's platform including the subscription price or other payments to directly interact with independents (Hagiu and Wright, 2015b, p. 163,165).

- Investment the operator makes to motivate the customer's efforts and ensuring that quality and trust benefit customers (Hagiu and Wright, 2015b, p.172).

Appendix 2 provides the data for the three agents and three affiliations collected for the 19 companies included in the sample. 


\subsection{Propositions}

Five propositions were developed anchored around the MSP logic model shown in Figure 4.2

1. MSPs enable affiliations between independents and customers anchored on the provision of complementary products with long shelf life and services that cannot be resold.

2. Independents set prices that enable them to adapt to private information that includes their costly effort and the nature of expectations with respect to other independents that join the platform.

3. Operators develop an affiliation with independents anchored on platformspecific investments including subscription price or fixed payments, and motivation efforts.

4. Operators develop an affiliation with customers anchored on platform-specific investments including subscription price, and the delivery of quality and trusted service.

5. Operators become proficient at developing relationships with independents, develop leadership roles in marketing and business development, and develop feedback systems to aggregate users' experience.

\subsection{New elements drawn from data}

Four new agents (i.e., actors other than Operator, Independent, and Customers) were identified by examining the data on the 19 companies in the sample. These 
new agents were first denoted as Agent A, Agent B, Agent C, and Agent D according to functions and key responsibilities they indicated related to protocol of inquiry. In order to organize data on new agents, evidence dealing with themes/ideas were sought and the four new agents $A, B, C, D$ were labeled as A- Third parties, BCatalysts, C- Affiliates, and D- Sides on demand.

Appendix 3 provides the evidentiary data that represent findings on relationships between MSP operator and each of the new agents for the 19 companies included in the sample.

For each of the new agents identified, Table 4.4 lists its key responsibilities observed from the data, the number of companies where the agent was observed, the companies that included different agents and the company web addresses.

Table 4. 4 New agents identified by examining the data on 19 companies

\begin{tabular}{|c|c|c|c|c|}
\hline New agent & Responsibilities & $\begin{array}{l}\text { Number of } \\
\text { companies } \\
\text { where } \\
\text { agent was } \\
\text { observed }\end{array}$ & $\begin{array}{l}\text { Companies } \\
\text { that include } \\
\text { the agent }\end{array}$ & $\begin{array}{l}\text { Companies' web } \\
\text { addresses }\end{array}$ \\
\hline $\begin{array}{l}\text { Agent A: } \\
\text { Third } \\
\text { parties }\end{array}$ & $\begin{array}{l}\text { Provide amenities } \\
\text { to attract and } \\
\text { retain Catalysts; } \\
\text { grow sides; offer } \\
\text { additional } \\
\text { services; handle } \\
\text { regulatory and } \\
\text { compliance; } \\
\text { provide tracking } \\
\text { and verification }\end{array}$ & 12 & $\begin{array}{l}\text { DoorDash; } \\
\text { Coursera; } \\
\text { Thrive } \\
\text { Market; } \\
\text { Lending } \\
\text { Loop; } \\
\text { Airsorted; } \\
\text { Helpling; } \\
\text { Farmlead; } \\
\text { Outschool; }\end{array}$ & $\begin{array}{l}\text { www.doordash.com } \\
\text { http://www.courser } \\
\text { a.org } \\
\text { https://thrivemarket } \\
\text {.com/ } \\
\text { https://www.lendin } \\
\text { gloop.ca/ } \\
\text { https://www.airsort } \\
\text { ed.uk/ } \\
\text { https://www.helplin } \\
\text { g.de/ }\end{array}$ \\
\hline
\end{tabular}




\begin{tabular}{|c|c|c|c|c|}
\hline & & & $\begin{array}{l}\text { Snappr; } \\
\text { Ahalogy; } \\
\text { Exitround; } \\
\text { MissionU; }\end{array}$ & $\begin{array}{l}\frac{\text { https://farmlead.co }}{\mathrm{m} /} \\
\frac{\mathrm{https}: / / \text { outschool.co }}{\mathrm{m} /} \\
\text { www.snappr.co } \\
\underline{\text { http://ahalogy.com }} \\
\underline{\text { https://exitround.co }} \\
\underline{\mathrm{m} /} \\
\underline{\text { https://www.missio }} \\
\text { nu.com }\end{array}$ \\
\hline $\begin{array}{l}\text { Agent B: } \\
\text { Catalysts }\end{array}$ & $\begin{array}{l}\text { Strengthen } \\
\text { affiliation } \\
\text { between } \\
\text { Independents and } \\
\text { Customers; } \\
\text { induce platform } \\
\text { revenue creating } \\
\text { more } \\
\text { transactions }\end{array}$ & 2 & $\begin{array}{l}\text { Instacart; } \\
\text { DoorDash; }\end{array}$ & $\begin{array}{l}\underline{\text { https://www.instaca }} \\
\underline{\text { rt.com }} \\
\text { www.doordash.com }\end{array}$ \\
\hline $\begin{array}{l}\text { Agent C: } \\
\text { Affiliates }\end{array}$ & $\begin{array}{l}\text { Grow number of } \\
\text { participants that } \\
\text { join sides and } \\
\text { receive } \\
\text { commissions and } \\
\text { bonuses }\end{array}$ & 5 & $\begin{array}{l}\text { Freightos; } \\
\text { Coursera; } \\
\text { Thrive } \\
\text { Market; } \\
\text { Lending } \\
\text { Loop; } \\
\text { MissionU; }\end{array}$ & $\begin{array}{l}\text { https://www.freight } \\
\text { os.com } \\
\text { http://www.courser } \\
\text { a.org } \\
\text { https://thrivemarket } \\
\text { com/ } \\
\text { https://www.lendin } \\
\text { gloop.ca/ } \\
\text { https://www.missio } \\
\underline{\text { nu.com }}\end{array}$ \\
\hline $\begin{array}{l}\text { Agent D: } \\
\text { Sides on } \\
\text { Demand }\end{array}$ & $\begin{array}{l}\text { Exploit potential } \\
\text { opportunities } \\
\text { that mutually } \\
\text { benefit MSP and } \\
\text { the sides on } \\
\text { demand }\end{array}$ & 3 & $\begin{array}{l}\text { Pillow; } \\
\text { MissionU; } \\
\text { Thrive } \\
\text { Market; }\end{array}$ & $\begin{array}{l}\text { http://www.pillow.c } \\
\text { om } \\
\text { https://www.missio } \\
\text { nu.com } \\
\text { https://thrivemarket } \\
\text {.com/ }\end{array}$ \\
\hline
\end{tabular}


The four new agents fulfill their responsibilities by affiliating with the Operator. The agents and their affiliations are described in the subsections 4.4.1 to 4.4.8

\subsubsection{New agent 1: Third parties (Agent A)}

Operators use third parties to grow sides, provide services, fulfill regulatory and compliance requirements, tracking and verification, and to provide amenities to Catalysts (Agent B). Operators do not want third parties to become a side that interacts directly with customers.

Twelve companies in the sample showed connections with third parties. four companies used third parties to grow sides, two companies provided additional services connecting with third parties, six companies fulfilled their regulatory and compliance requirements through third parties, four companies did tracking and verifications through third parties, and one company used third-party services to provide amenities to attract and retain their Catalysts.

\subsubsection{New Agent 2: Catalysts (Agent B)}

Catalysts engage with independents and customers and represent the operator. The operator remunerates the catalysts for their service.

Two companies in the sample employed catalysts. The grocery sales and delivery company Instacart uses "Shoppers" who represent the category of catalysts that click, collect and deliver grocery items to customers devoting their free time and vehicle to gain an income. The food and goods delivery company DoorDash 
receives orders and assigns "Dashers" who represent the category of catalysts that pick and deliver orders devoting their time and vehicle to gain an income. In addition to this income "Dashers" also become eligible to amenities provided by the operator through third-party services.

\subsubsection{New agent 3: Affiliates (Agent C)}

Affiliates promote the operator's business and help grow the independent and customer bases. Operators pay a commission or bonus to affiliates when the participants connected through affiliates interact with the sides to exchange value. Operators provide affiliates with website links, banners, and promotional items to attract new participants.

Five companies in the sample use affiliates to grow their businesses. Freightos affiliates refer shippers, and receives a bonus on their first booking; Coursera pays a commission to their affiliates on purchases made through affiliation; Thrive Market pays to their affiliates for every member they add; Lending Loop pays their affiliates a commission for referrals, while MissionU provides a cashback bonus to their affiliates as well as referred student, upon every student enrolled through such affiliation.

\subsubsection{New Agent 4: Side(s) on demand (Agent D)}

Operators provide potential engagement opportunities for side(s) on demand. Independents or customers may benefit by increased direct or indirect network 
effect resulted by this potential engagement between the MSP operator and the side(s) on demand. Three companies in the sample showed side(s) on demand. Pillow, a short-term rental company had potential rent seekers as a side on demand while the independents and customers that belonged to MSP were property owners and residents. MissionU had potential employers as a side on demand while independents and customers that belonged to MSP were educators and students. Thrive Market had the concept of one free membership offered to a deserved family for every member who signed up, and, a list of low-income families was sought as a side on demand.

\subsubsection{New Affiliation 1: Third Parties - Operator Affiliation}

The affiliation between the third parties and the operator is specified in terms of the:

- Investment that third parties make in the operator's platform to be able to sell (products/services to catalysts), provide (additional services, regulatory and compliance requirements, tracking verification services to operator to complete MSP transactions), or increase their reputation (adding participants to sides)

- Investment that operator makes to purchase and attract third party products and services 


\subsubsection{New Affiliation 2: Catalysts - Operator Affiliation}

The affiliation between the catalysts and the Operator is specified in terms of the:

- Investment that catalysts makes to be able to serve independents and customers on behalf of the operator (devoting free time and their own vehicle)

- Investment that operator makes to motivate catalysts' effort and pay compensation for their services

\subsubsection{New Affiliation 3: Affiliates - Operator Affiliation}

The affiliation between the affiliates and the operator is specified in terms of the:

- Investment that affiliates makes to find new entrants to join the platform (promotions, advertising, and leveraging network)

- Investment the operator makes to motivate the affiliates' effort and pay commissions and bonuses for their services

\subsubsection{New Affiliation 4: Sides on Demand - Operator Affiliation}

The affiliation between the sides on demand and the operator is specified in terms of the:

- Investments the sides on demand make exploiting opportunities with operator's platform (opportunity cost) 
- Investments the operator makes to attract and motivate sides on

demand (marketing, information)

Appendix 4 provides the data for the four new agents and four new affiliations collected for the 19 companies included in the sample.

\subsection{Representation drawn from corpus and data}

Data examined from the sample added four new agents. Figure 4.3 builds on

Figure 4.2 and adds the four new agents indicated as 4,5,6, and 7.

Figure 4. 3 Representation drawn from corpus and data

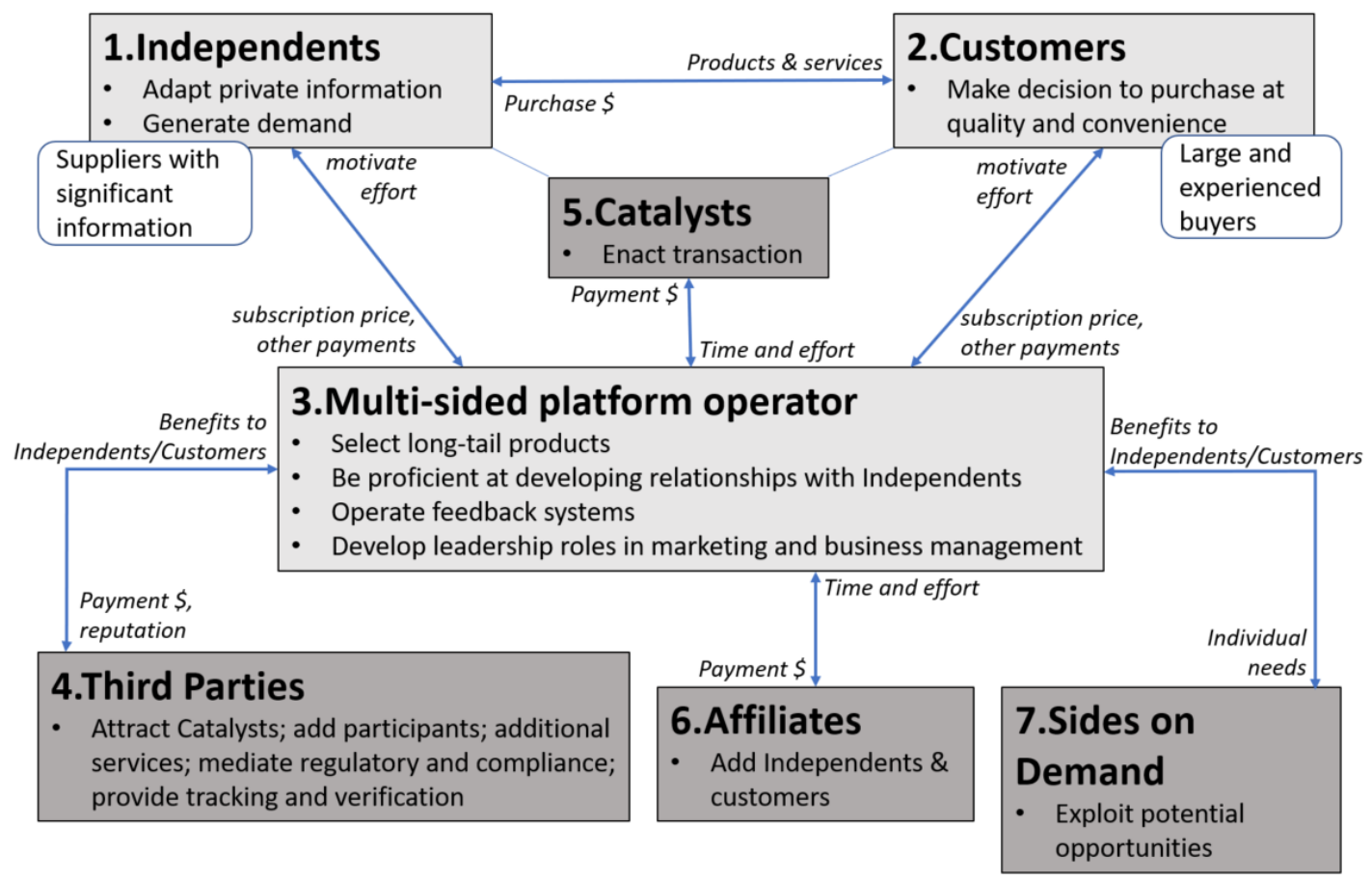




\subsection{Propositions around the new model}

Four new propositions were developed anchored around the new model:

1. Operators employ catalysts as an interface between the operator and each of the sides to enhance the affiliation between independents and customers and induce platform revenue through increased interactions.

2. Operators pay commissions and bonuses to affiliates to grow their number of independents and customers.

3. Operators engage third parties to provide services, but do not enable them to interact directly with customers.

4. Operators interact with sides in waiting to shape opportunities that benefit independents and/or customers.

\subsection{Summary}

Chapter 4 presented the results obtained by analyzing 19 MSP companies. The analysis was based on MSP logic discussed in Hagiu and Wright (2015a; 2015b; 2015c) and applications to specific strategies provided in Hagiu and Altman (2017). Sample criteria and selection process, and the company information provided background to companies that were examined. Representation drawn from the corpus was explained in terms of agents and affiliations discussed in Hagiu and Wright (2015a; 2015b; 2015c) and applications to specific strategies provided in Hagiu and Altman (2017). Four new agents were found by examining 19 companies, and the affiliation between each of these new agents and the operator were 
described. These new agents did not directly interact in a trade or exchange with customers and therefore distinguished from the definition of an independent that affiliated with the Operator. The representation drawn from the corpus incorporated examined data and included 7 agents and affiliations. Four propositions were developed anchored on new agents and affiliations.

The results present research findings of four new agents and affiliations. In line with the expected deliverables, (i) a representation from corpus that explains the logic of an MSP (ii) a set of propositions developed anchored around the representation from the corpus, (iii) new findings from examining data on 19 MSP startup companies during their growth stage, (iv) a representation that incorporates data on startups to explain the logic of an MSP and ( $v$ ) a set of new propositions developed anchored around the new model representing new agents and affiliations were presented. 


\section{DISCUSSION}

Chapter 5 is organized into eight sections. Section 5.1 details the Hagiu and Wright formulation of an MSP and lead the discussion into significant findings of this research. Section 5.2 discusses the new agent, Third Parties. Section 5.3 discusses the new agent Catalysts. Section 5.4 discusses the new agent, Affiliates followed by the section 5.5 discussion on the new agent, Sides on Demand. Section 5.6 qualifies direct interactions based on results, section 5.7 links the research with reviewed literature, and section 5.8 concludes.

\subsection{MSP logic from corpus and findings of the research}

Researcher's examination of the corpus of MSP, aimed at detailing Hagiu and Wright formulation of a MSP. An intermediary's choice between functioning as a marketplace or reseller and how to optimally position an intermediary between two different modes (Hagiu and Wright, 2015a), the economic trade-offs that drive the decision related to alternatives of functioning as a vertically integrated (VI) firm, reseller or an input supplier (Hagiu and Wright, 2015b), and the firm's control of service provision versus the agent's control of the service provision (Hagiu and Wright, 2015c) were examined. These mathematically supported discussions along with the applications of strategies (Hagiu and Altman, 2017) provided the base for examining the 19 companies.

Companies in the sample were qualified as MSP companies provided that they served multiple groups and facilitated interactions between customers or groups 
(Hagiu and Altman, 2017, p.96). Hagiu and Wright (2015b, p.163) definition

confirms the two key features of MSPs as;

- Enabling direct interactions between two or more distinct sides, and

- Each side being affiliated with the platform

The companies in the sample were examined to identify the distinct sides, namely, independents and customers, and the affiliations between independents and customers, and between each of them and the operator. The term "direct interaction" implies that independents and customers retain control over the key terms of the interaction (Hagiu and Wright, 2015b, p.163) to the extent that sides retain residual control rights (ownership) over the goods traded (Hagiu and Wright, $2015 b, p, 170)$. The key terms of the interaction could be the pricing, bundling, marketing and delivery of the goods or services traded, the nature and quality of the products and services, and the terms and conditions (Hagiu and Wright, 2015b, p.163).

The term "affiliation" implies that each side being affiliated with the platform makes platform specific contributions as a necessity for them to be able to directly interact with each other (Hagiu and Wright, 2015, p.163) and these investments could be a fixed access fee, expenditure of resources, or an opportunity cost.

The independents and the customers in each of the companies in the sample were affiliated to the platform and had direct interactions exchanging value for the products and services provided through the platform. Examination of the sample revealed that there were other entities that engaged with the platform in addition 
to those that were identified as independents and customers. These entities demonstrated affiliation with the operator, without having any direct interaction with customers. Each of these entities provided resources or held an opportunity cost as an investment while the operator either compensated money value or satisfied a need in return, demonstrating the affiliation. While affiliation by the sides help distinguish MSPs from Input suppliers (Hagiu and Wright, 2015b, p.164), affiliation alone is not sufficient to create a MSP (Hagiu and Wright, 2015b, p.164). Since there were no direct interactions found between these entities and either independents or customers, the new entities were identified as four new agents that enhance the functionality of the MSP operator. The four new agents were identified as (A) Third Parties, (B) Catalysts, (C) Affiliates, and (D) Side(s) on demand.

\subsection{New agent 1: Third parties}

Of the 19 companies examined, 12 companies had affiliated with third parties in a variety of four ways: to grow sides; provide services; fulfill regulatory and compliance requirements; tracking and verification, and provide amenities to another entity. Figure 5.1 shows the connection between MSP operator and the third parties.

The affiliation between the third parties and the operator is specified in terms of the:

- Investment that third parties make in the operator's platform to be able to sell (products/services to catalysts), provide (additional services, 
regulatory and compliance requirements, tracking verification services to operator to complete MSP transactions), or increase their reputation (adding participants to sides)

- Investment that operator makes to purchase and attract third party products and services

Figure 5. 1 Representation of the affiliations between MSP operator and third parties

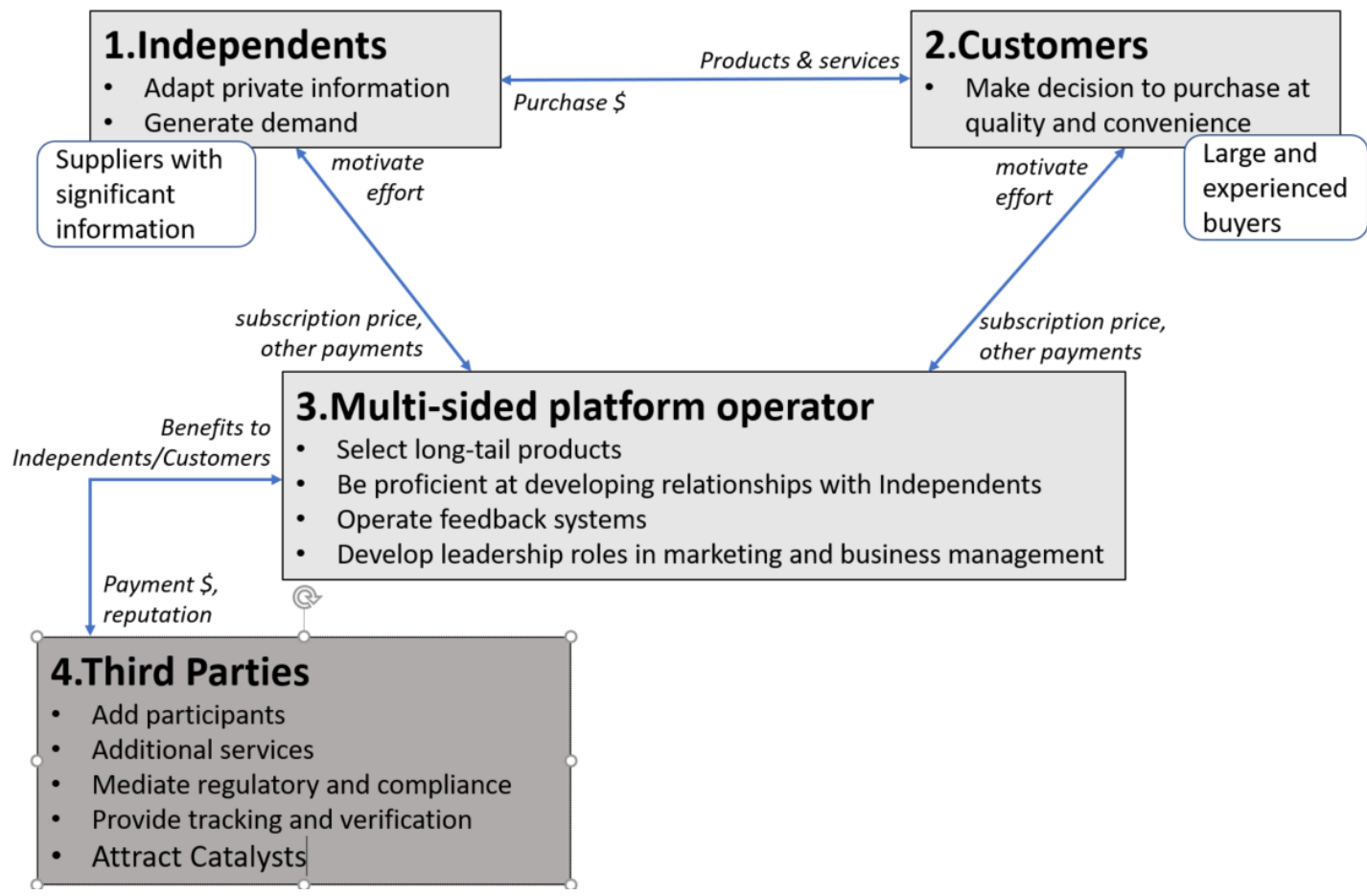

5.2.1 Affiliation with third parties to add participants:

MSP Operators grew their side(s) by affiliating with third parties. Independents' profits depend on how many other suppliers join and if doing so gives them nonnegative profits (Hagiu and Wright, 2015a, p.190), and Independents care to capture value through indirect network effects (Hagiu and Wright, 2015b, p.164). 
MSP operator by affiliating with third parties grow the number of independents as well as customers on each side. Coursera affiliate with businesses, governments, and organizations providing flexible pricing, customized offering, progress tracking and real-time analytics in the expectation these third parties select Coursera to provide learning opportunities to their employees as a part of their employee development programs. Thrive Market connects with non-profit organizations to qualify needy families as recipients of an opportunity to receive free memberships, and conduct advocacy campaigns. Lending Loop affiliate with distributor and referral partners expecting them to introduce their partners and business owners to Lending Loop services. Airsorted affiliate with cleaners to impress customers and grow customer side.

\subsubsection{Affiliation with third parties to provide additional services to their} customers:

MSP operators offer additional services to their customers, by affiliating with third parties. Helpling provides other household services to their customers through partner companies when customers book on demand cleaners from Helpling. Farm Lead affiliate with grain testing labs to provide grain testing facilities to farmers so that farmers can gain competitive prices for their tested grains. Lending Loop also allows small businesses to purchase products through financing by affiliating with vendor partners, in addition to finding affordable financing for their businesses through Lending Loop. 


\subsubsection{Affiliation with third parties to handle regulatory and compliance}

requirements

MSP Operators handle regulatory and compliance matters by affiliating with third parties. This enables independents and customers complete regulatory requirements and also find out if the contracting independents and customers comply the standards. Lending Loop uses a Canadian Chartered Bank to handle all money that is stored on the platform and registered as an Exempt Market Dealer in all provinces and territories. DoorDash conducts satisfactory background checks and checks Dashers' clean driving records. Helpling insured cleaning aids who are tested for skills competence, and snappr obtains insurance for photographers to cover all bookings, photography equipment theft-damage-loss, public liability and for professional indemnity. By affiliating with third parties to provide the regulatory and compliance needs that are necessary, enhances direct interactions between the independents and customers.

\subsubsection{Affiliation with third parties to track and verify}

MSP Operators use third-party tracking and verification as a feedback measure. Ahalogy uses third-party tracking to select best high engagement creation. Exitround facilitates consultation with a Target Acquisition Curator for company acquirers, their Customers side. MissionU partners with leading companies to ensure students learn what's needed to succeed in the job, and Coursera affiliate with beta testers who are enthusiastic in helping to explore courses before they 
open to the public, and give feedback to instructors. These companies using thirdparty services enhance the quality of product/service to independents and customers.

\subsubsection{Affiliation with third parties to provide amenities to Catalysts}

MSP Operators provide amenities to attract and retain catalysts by affiliating with third parties. DoorDash provides to "Dashers", a commercial auto insurance, access to health care coverage, subsidized member fee for an application for tracking their revenue and expenses for tax purposes, and access to daily pay company to receive wages, by affiliating with third parties. These amenities attract and retain Dashers who deliver orders placed by customers.

\subsection{New Agent 2: Catalysts}

Formulation of the direct interaction between the independents and customers defined in an MSP (Hagiu and Wright 2015b, p.163) seems to be incomplete for delivery MSPs without catalysts, as observed in the sample. The two delivery MSPs Instacart and DoorDash, both used catalysts to pick and deliver orders. Catalysts engage with independents and customers and represent the operator. The operator remunerates the catalysts for their service. Figure 5.2 shows the connection between MSP operator and catalysts.

The affiliation between the catalysts and the operator is specified in terms of the: 
- Investment that catalysts make to be able to serve independents and customers on behalf of the operator (devoting free time and their own vehicle)

- Investment that operator makes to motivate catalysts' effort and pay compensation for their services

Figure 5. 2 Representation of the affiliation between MSP Operator and Catalysts

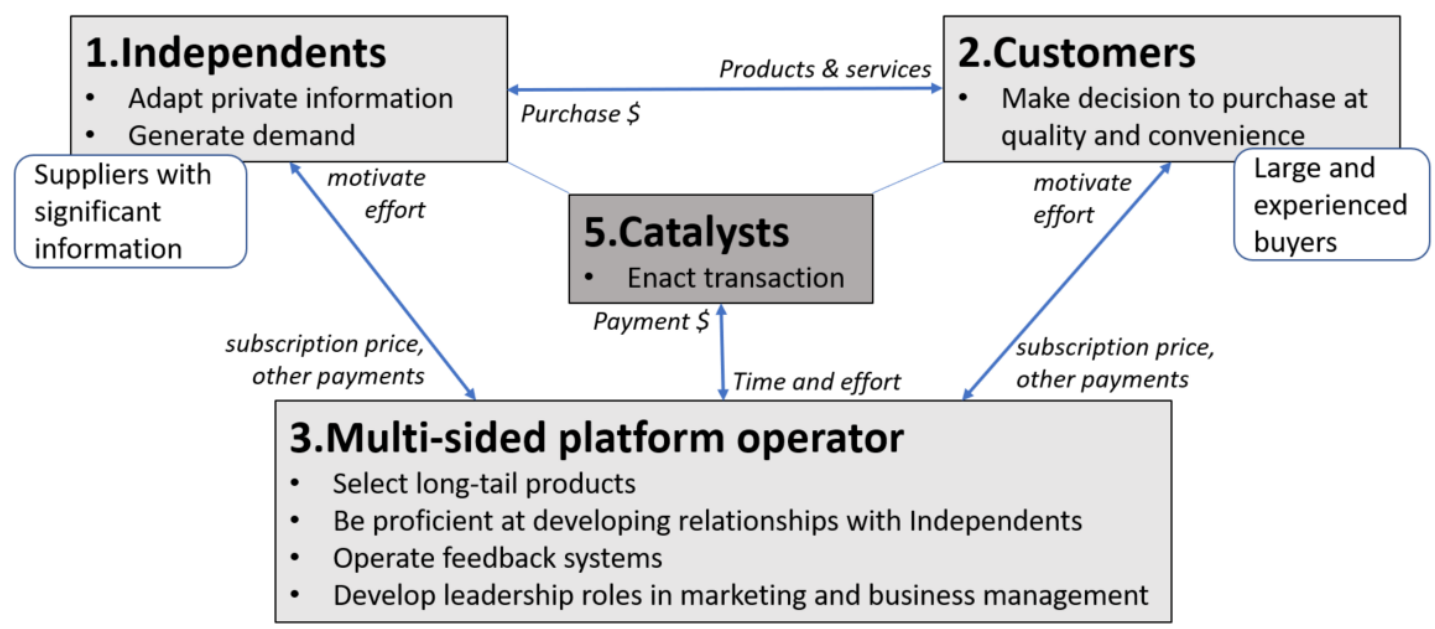

Catalysts enhance the affiliation between sides, as well as help induce revenue to independents by providing good customer service. The grocery sales and delivery company Instacart uses "Shoppers" who act as catalysts that click, collect and deliver grocery items. The food and goods delivery company DoorDash receives orders and assigns "Dashers" who act as catalysts that pick and deliver orders. In both these companies, the interaction between independents and customers would not be completed without the presence of catalysts. 


\subsection{New Agent 3: Affiliates}

Of the 19 companies examined, five companies affiliated with affiliates to grow sides. Affiliates promote operator's business and help grow the independent and customer bases. Figure 5.3 shows the connection between MSP operator and the affiliates.

Operators pay a commission or bonus to affiliates when the participants connected through affiliates interact with the sides to exchange value. Operators provide affiliates with website links, banners, and promotional items to attract new participants. Five companies in the sample used affiliates to grow their businesses. Freightos affiliates sign up, refer shippers to Freightos website and receive $\$ 100$ bonus on the shipper's first booking. Coursera pays a $20 \%$ commission to their affiliates on purchases made through affiliation. Thrive Market pays their affiliates $\$ 25$ for every member they add. Lending Loop pays their affiliates a commission for referring a lending partner upon publishing content and refer readers to Lending Loop, while MissionU provides a cashback bonus to their affiliates as well as referred student, upon every student enrolled through an affiliation.

The responsibility of the affiliates seems obvious, but the affiliation helps MSP Operator add participants to Independents' and Customers' sides. As noted in section 5.2.1 independents' profits depend on how many other suppliers join and if doing so gives them non-negative profits (Hagiu and Wright, 2015a, p.190), and independents care to capture value through indirect network effects (Hagiu and Wright, 2015b, p.164). 
The affiliation between the affiliates and the operator is specified in terms of

the:

- Investment that affiliates makes to find new entrants to join the platform (promotions, advertising, and leveraging network)

- Investment that operator makes to motivate the affiliates' effort and pay commissions and bonuses for their services

Figure 5. 3 Representation of the affiliation between MSP Operator and Affiliates

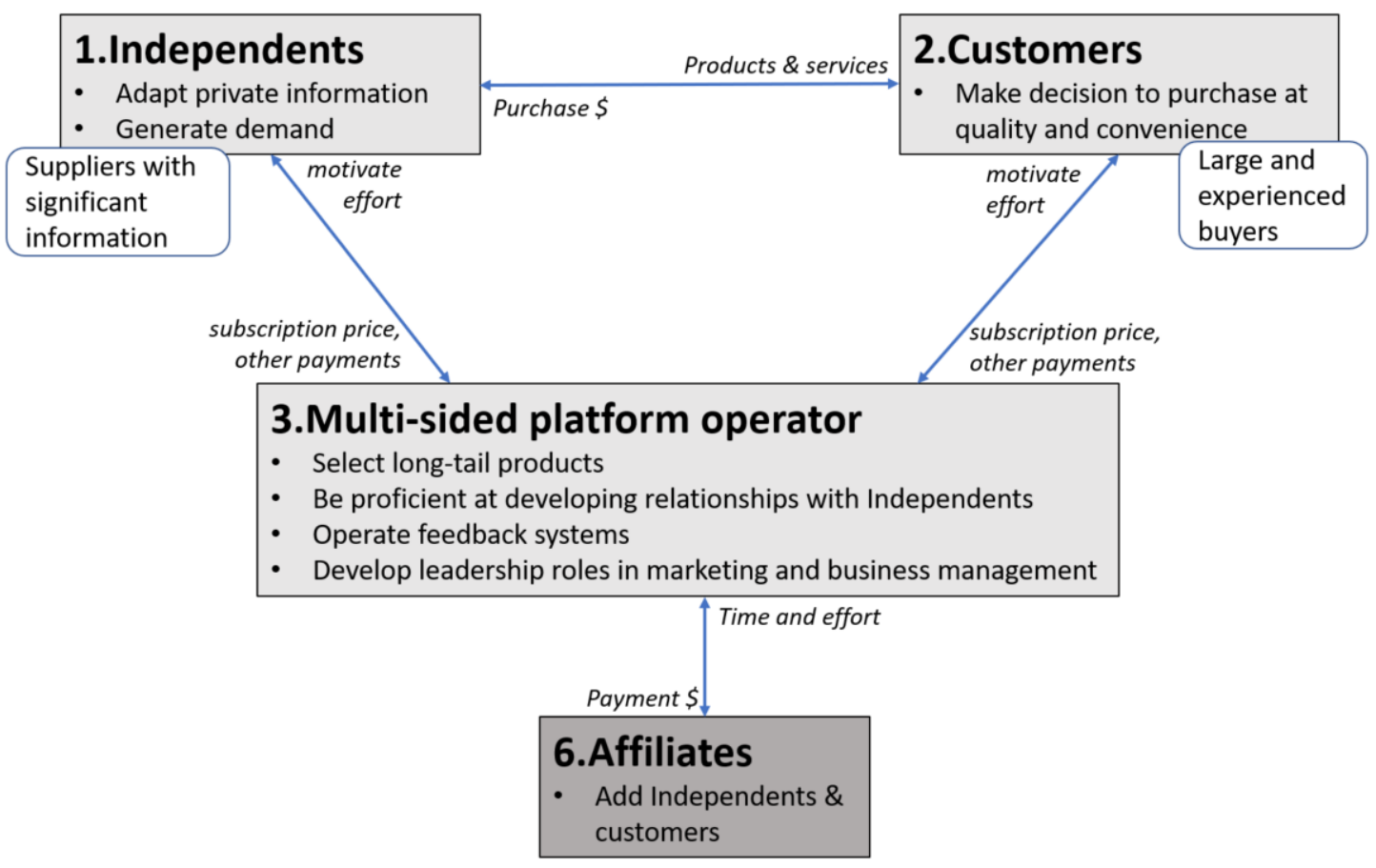

\subsection{New Agent 4: Side(s) on demand}

MSP Operators provide potential engagement opportunities to external entities who seek to fulfill their needs. By creating such an affiliation, operators enable direct or indirect network effects that benefit independents and/or customers. Figure 5.4 shows the connection between MSP operator and the sides on demand. 
The affiliation between the sides on demand and the operator is specified in terms of the:

- Investments the sides on demand make exploiting opportunities with operator's platform

- Investments the operator makes to attract and motivate sides on demand

Figure 5. 4 Representation of the affiliation between MSP Operator and the Sides on Demand

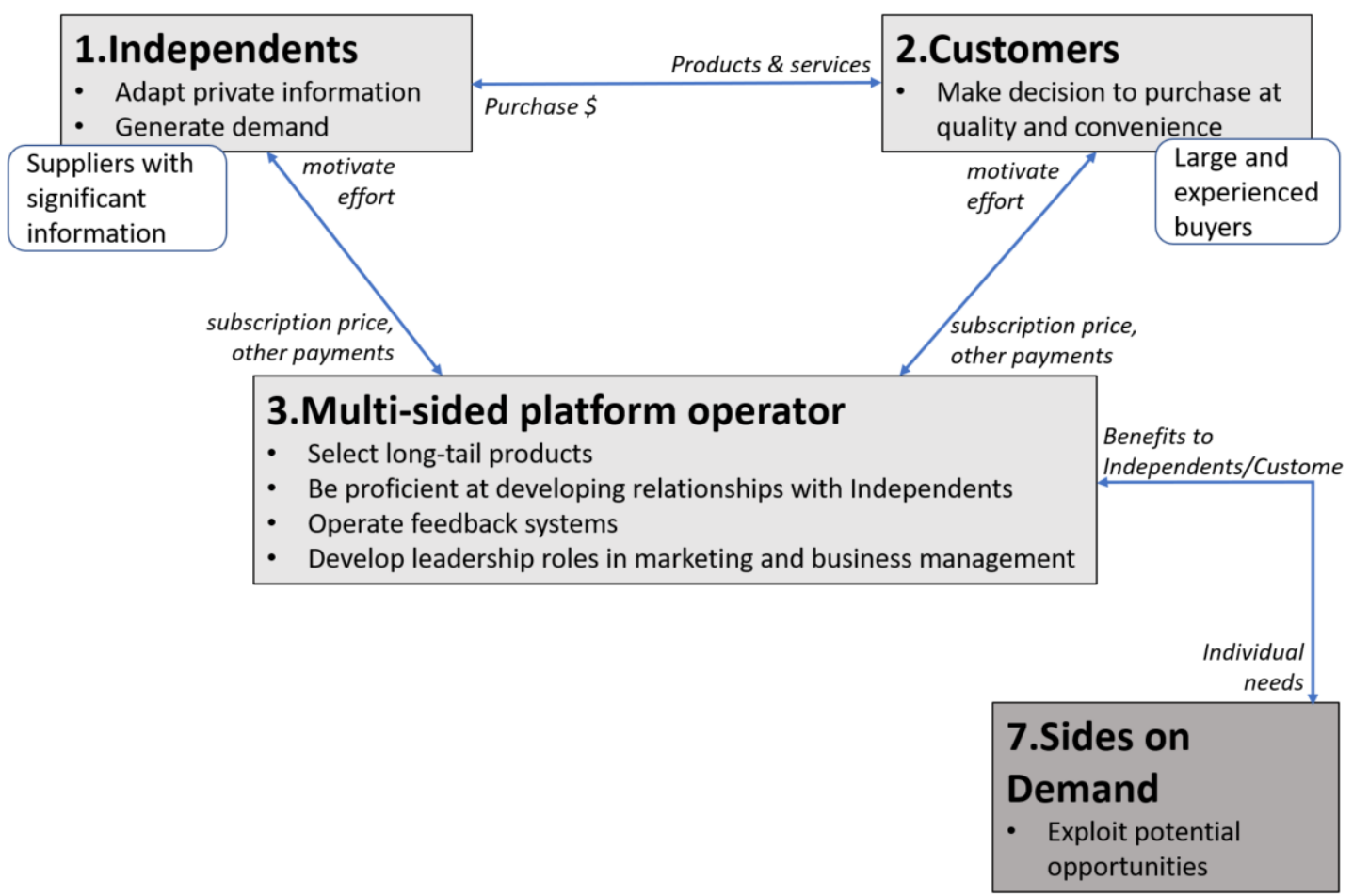

Three companies in the sample showed side(s) on demand. Pillow, a short-term rental company had potential rent seekers as a side on demand while the independents and customers that belonged to MSP were property owners and residents. Operator affiliated with rent seekers found potential customers for 
residents who want to rent their homes on short-term, and residents shared the revenue with property owners who allowed them to rent their homes as a special condition in their leasing agreement. MissionU had potential employers as a side on demand while independents and customers that belonged to MissionU MSP were educators and students. MissionU affiliate with employers to provide an opportunity for students to find jobs. Thrive Market had the concept of one free membership offered to a deserved family for every member who signed up and engaged one side on demand, a list of low-income families who could be the recipients of this opportunity.

With Pillow and MissionU examples, sides on demand complete a business cycle benefitting Customers, while in Thrive Market, sides on-demand help grow sides benefitting indirect network effects to independents

\subsection{Direct interactions}

In this paper, MSP is recognized as defined by Hagiu and Wright (2015b, p.163), that enable direct interactions between independents and customers and that independents and customers are affiliated with the platform. Direct interactions, therefore, exists between independents and customers and they retain control over key terms of the interaction. Independents and customers make platform-specific investments in order for them to be able to interact with each other (Hagiu and Wright, 2015b, p.163). 
In the examination of the sample of 19 companies, the direct interaction between independents and customers were identified by answering the question “what transaction do MSP enable?" as listed in Table 4.1. This transaction is enabled through affiliations between (a) Independents and Customers, (b) Independents and Operator, and (c) Customer and Operator. The affiliation between independents and operator and the affiliation between customers and operator explained how the direct interactions were enabled in each MSP. The affiliation between independents and customers then demonstrated the control over direct interaction. Direct interactions between independents and customers set MSPs apart from resellers, and vertically integrated firms and platform affiliation by independents and customers set MSPs apart from input suppliers (Hagiu and Wright, 2015b, p.164).

As shown in the representation drawn from the corpus in Figure 4.2, independents bear the attributes of having significant information advantage (Hagiu and Wright, 2015a, p.198) and customers bear the attribute of being large and experienced buyers (Hagiu and Wright, 2015b, p.172). For the direct transaction to take place, independents must decide their affiliation based on their private information (Hagiu and Wright, 2015b, p.162,167), which are non-transferable, and the chosen transferable action that suits them to adapt their decisions to their private information. At the same time, customers must decide their affiliation and purchase decisions (Hagiu and Wright, 2015b, p.166, 188). This affiliation is strengthened by the independents effort to grow their private information and 
thereby generate demand, to attract more customers for their offer. Independents' affiliation with the operator must provide motivation effort for the independent to best adapt their decisions to their private information (Hagiu and Wright, 2015a, p.186) and select transferable actions that control key terms of the interaction. This enables the direct transaction between independents and customers, where independents can provide service directly to customers, and customers act their purchase decision.

\subsection{Discussion of results relating to literature}

This section discusses relating to literature, the effect of holding private information and control rights over the transferable decision, network effects, and the hybrid modes of operation.

The emphasis on independents' private information does not guarantee that independents only hold important private information. Both sides, independents and the operator may have private information that helps adapt their decisions on the effectiveness of transferable actions (Hagiu and Wright, 2015b, p.169). They conduct activities (ex: marketing, advertising) to generate demand and attract clients. Independents do not take into account the other independents that join when choosing their marketing activities (Hagiu and Wright, 2015a, p.191). Therefore, some marketing activities which may not be specific to independents private information may best carry out by the operator thus retaining some control rights on the transferable decision with the operator. The sample demonstrated the 
affiliations that operators could exercise in order to meet best interests of multiple independents. This helps mitigate the pessimistic expectations of independents who would potentially join. These affiliations tell us that MSPs do not exist in isolation. Although some control rights over transferable actions are being allocated to independents, the operator has a responsibility to provide motivation and the tools and techniques to ease the direct interaction between independents and the customers. This does not rule out the importance of private information by the independents but enhances the direct interaction between independents and customers.

An independent's profit increases when more independents join the side, and this depends on how positive their expectations are in deciding to join the side. Network effects merely don't decide or define an MSP but create and capture economic value (Hagiu and Wright, 2015b, p.171), thus significantly affects participants' decision to join. Because of the network effects, users will pay more to access a bigger network and the margins improve and users grow, as opposed to traditional businesses where growth beyond some point lead to diminishing returns (Eisenmann et al., 2006). The affiliations found between operator and the four new entities, namely, third parties, catalysts, affiliates, and the sides on demand, create network effects that benefit the direct interaction between the independents and customers. This result connects Evans and Schmalensee (2016) suggestion of MSPs generating their customers and enabling interactions as opposed to ordinary businesses attracting customers and selling on profits. Figure 5.5 shows the 
affiliations that were observed in the sample, that supports the direct interaction between the independents and customers.

Figure 5. 5 Affiliations between all agents that enhance the direct interaction between Independents and Customers

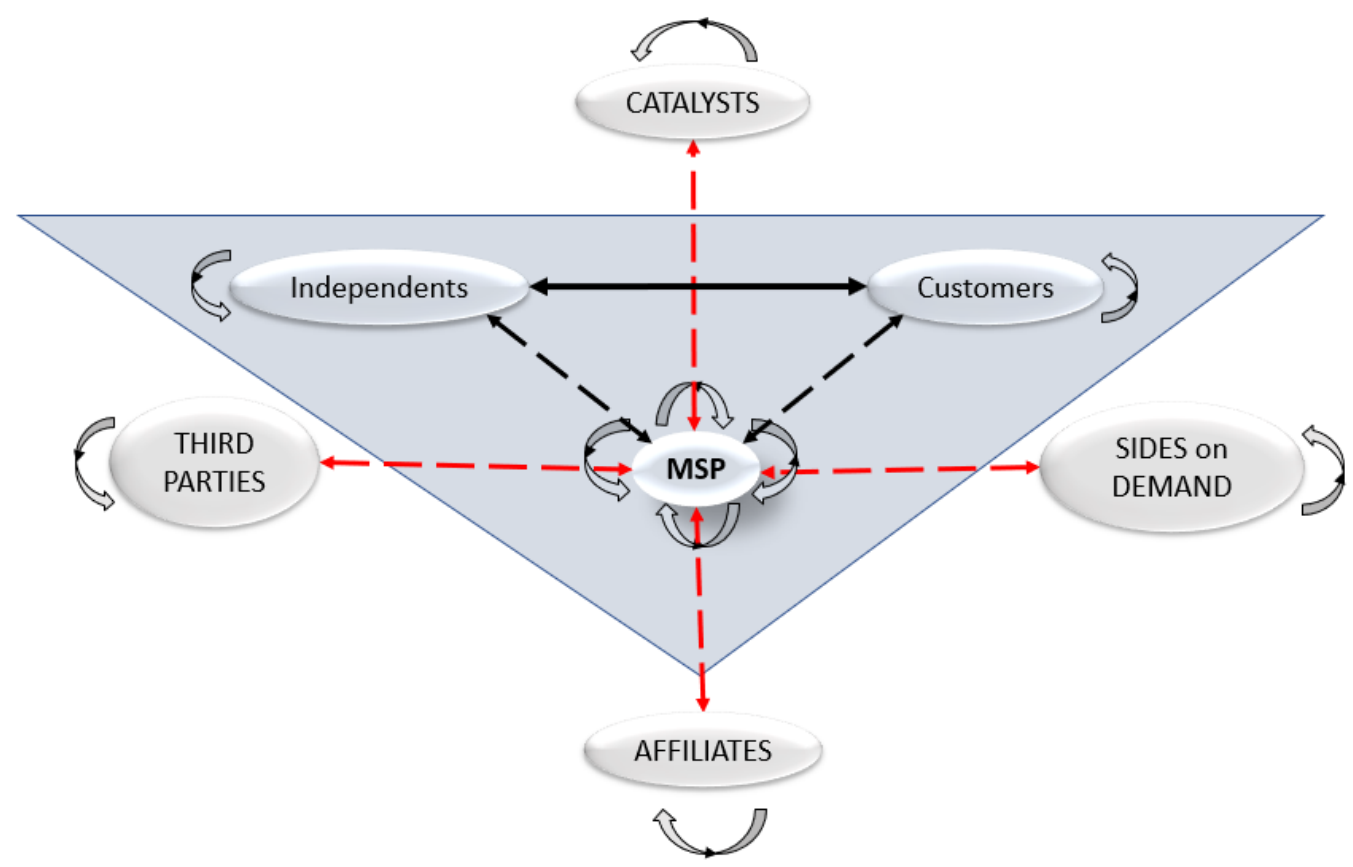

Conforming the discussion about handing over some control rights over transferable actions to either party, the companies in the sample showed a tendency towards a hybrid mode of operation. This elaborates Hagiu and Wright (2015a, p.192,193) recommending adopting a hybrid structure involving reseller mode when (i) the operator has an information advantage over independents and (ii) to overcome pessimistic expectation formed by potential independents' decision to join. However, the direct interaction between independents and customers based on residual control rights (ownership) over the goods traded promotes the 
investment made by independents. As Incentive Systems theory of the firm explains, the ownership of assets is not contractible and provides incentives that cannot be replicated via contract (Gibbons, 2005, p.207). Allocation of control rights to independents and operator over certain decisions can be explained according to Property Rights theory of the firm as parties share surplus from their specific investments and that becomes an incentive to their platform investments (Gibbons, 2005, p.205). Further, the total surplus will be available to share because the integration decision determines ex-ante investments.

\subsection{Summary}

Chapter 5 discussed the results highlighting the main findings. Detailing from a corpus of the formulation of an MSP followed by an explanation of four new agents and their affiliation with the platform. Direct interactions were qualified as applicable in this research, and results were discussed relating to literature. 


\section{CONCLUSION}

Chapter 6 consists of 3 sections. Section 6.1 highlights the importance of the research. Section 6.2 provides limitations of the research, and Section 6.3 suggests future work.

\subsection{Importance}

The data gathered by examining 19 MSP startup companies demonstrated direct interactions between sides and their affiliation with the operator. It also revealed that MSPs do not operate in isolation but create an affiliation with other entities that enhance the direct interaction between the independents and customers. MSP startups in the sample raised funding ranging from $\$ 1.52 \mathrm{M}$ (Outschool, founded in 2016 ) to $\$ 674.8 \mathrm{M}$ (Instacart, founded in 2012 ), and reported trailing twelve months revenue of $\$ 1 \mathrm{M}$ or above. Four new agents and affiliations that were not present in the corpus were existing in the growth stage MSP startups that were examined. Of the 19 MSP startups in the growth stage 15 companies demonstrated any one or several of the affiliations between MSP operator and the new agents. This main contribution adds new knowledge with respect to growth stage MSP startups.

This research interprets and advance extant literature to explain the affiliations among independent suppliers, customers, and MSP operator, and the research findings introduce four agents and their affiliation with MSP operator that enable the growth of a MSP startup. A model that explains these affiliations provides a set of propositions. The results also imply that MSPs do allocate control rights over 
transferable actions in two important ways: (i) allowing residual control rights to independents over the goods traded expecting independents to take control of the key terms of the transaction, and, (ii) retaining control rights over some actions that benefit sides over and above the actions performed by the independents. As such the four new agents belong affiliations with the operator, without having direct interactions with either independents or customers. New agents and their affiliation with the MSP operator strengthens the affiliation and increase the interactions between the independents and customers, thereby enabling the MSP startups to grow during the growth stage.

\subsection{Limitations}

The research sample consisted of 19 companies and considered a small sample. A larger sample would have helped determine more interactions and visibility of variations. Researcher's own judgment about interpreting the website information to decide MSP companies and determine affiliations between entities limits scope. Finally, the pool included companies launched at different years, therefore generalization will not be feasible on the data obtained from a company launched in 2012 and one launched in 2016.

\subsection{Suggestions for future work}

Propositions were developed from the representation from the corpus as well as the representation after sample data were incorporated. Future researchers may 
develop testable hypotheses from these propositions. Future researchers may suggest a taxonomy of MSPs, a classification into subcategories based on affiliations. Another important area of research would be to clarify funding/growth relationship of MSP startups during the growth stage.

MSPs have become an important element in creating economic value, and contribution of this research towards finding a logic for MSP startups during their growth stage brought in four new agents and explanatory model providing insights to startup teams. It is important for entrepreneurs to build capabilities and leverage their network to affiliate with agents other than the sides that directly interact to exchange value. Ability to attract external resources enhance MSP startup outcomes. MSP startups during their growth stage, do not operate in isolation restricting its affiliations to sides who directly interact with each other but also affiliate with other entities to enhance those direct interactions - a revelation that is not explained in the literature about the logic of the growth of MSPs. 


\section{APPENDICES}

Appendix 1: Funding and estimated revenue for 19 companies included in the sample

\begin{tabular}{|c|c|c|c|c|c|c|c|}
\hline & $\begin{array}{l}\text { Company's } \\
\text { name, "alias", } \\
\text { and web } \\
\text { address }\end{array}$ & $\begin{array}{l}\text { Year } \\
\text { founded }\end{array}$ & $\begin{array}{l}\text { Estimated } \\
\text { revenue }\end{array}$ & $\begin{array}{l}\text { Amount } \\
\text { raised }\end{array}$ & $\begin{array}{l}\text { Latest } \\
\text { funding }\end{array}$ & $\begin{array}{l}\text { Latest } \\
\text { funding } \\
\text { type }\end{array}$ & $\begin{array}{l}\text { Funding } \\
\text { status }\end{array}$ \\
\hline 1 & $\begin{array}{l}\text { Maplebear, Inc. } \\
\text { I "Instacart" } \\
\text { www.instacart. } \\
\underline{\text { com }}\end{array}$ & 2012 & $\$ 67.7 \mathrm{M}$ & $\begin{array}{l}\frac{\$ 674.8 \mathrm{M}}{\text { in } 7} \\
\underline{\text { rounds }}\end{array}$ & $\begin{array}{l}\$ 400 M \\
\text { / Mar } \\
2017\end{array}$ & $\begin{array}{l}\text { Series } \\
\text { D }\end{array}$ & $\begin{array}{l}\text { Late } \\
\text { Stage } \\
\text { Venture }\end{array}$ \\
\hline 2 & $\begin{array}{l}\text { Tradeos, Ltd. I } \\
\text { "Freightos" } \\
\underline{\text { www.freightos. }} \\
\underline{\text { com }}\end{array}$ & 2012 & $\$ 5.8 \mathrm{M}$ & $\begin{array}{l}\frac{\$ 55.9 \mathrm{M}}{\text { in } 6} \\
\underline{\text { rounds }}\end{array}$ & $\begin{array}{l}\$ 25 M / \\
\text { Mar } \\
2017\end{array}$ & $\begin{array}{l}\text { Series } \\
\text { B }\end{array}$ & $\begin{array}{l}\text { Early } \\
\text { Stage } \\
\text { Venture }\end{array}$ \\
\hline 3 & $\begin{array}{l}\text { Coursera, Inc. I } \\
\text { "Coursera" } \\
\text { www.coursera. } \\
\text { org }\end{array}$ & 2012 & $\$ 19.7 \mathrm{M}$ & $\frac{\$ 210.1 \mathrm{M}}{\underline{\text { in } 7}}$ & $\begin{array}{l}\text { \$64M / } \\
\text { Jun } \\
2017\end{array}$ & $\begin{array}{l}\text { Series } \\
\text { D }\end{array}$ & $\begin{array}{l}\text { Late } \\
\text { Stage } \\
\text { Venture }\end{array}$ \\
\hline 4 & $\begin{array}{l}\text { Cohealo Inc. I } \\
\text { "Cohealo" } \\
\text { http://cohealo. } \\
\underline{\text { com }}\end{array}$ & 2012 & $\$ 3.6 \mathrm{M}$ & $\begin{array}{l}\frac{\$ 12.15 \mathrm{M}}{\underline{\text { in } 3}} \\
\underline{\text { rounds }}\end{array}$ & $\begin{array}{l}\$ 2 M / \\
\text { Sep } \\
2016\end{array}$ & $\begin{array}{l}\text { Series } \\
\text { A }\end{array}$ & $\begin{array}{l}\text { Early } \\
\text { Stage } \\
\text { Venture }\end{array}$ \\
\hline 5 & $\begin{array}{l}\text { MLW Squared, } \\
\text { Inc. I } \\
\text { "Ahalogy" } \\
\text { www.ahalogy.c } \\
\underline{\text { om }}\end{array}$ & 2012 & $\$ 2.9 \mathrm{M}$ & $\begin{array}{l}\$ 10.2 \mathrm{M} \\
\frac{\text { in } 4}{\text { rounds }}\end{array}$ & $\begin{array}{l}\$ 3 M / \\
\text { Jul } \\
2016\end{array}$ & $\begin{array}{l}\text { Series } \\
\text { unkno } \\
\text { wn }\end{array}$ & $\begin{array}{l}\text { Status } \\
\text { unknow } \\
\text { n }\end{array}$ \\
\hline 6 & $\begin{array}{l}\text { Exitround, LLC } \\
\text { I "Exitround" } \\
\text { www.exitround } \\
\text {.com }\end{array}$ & 2013 & $\$ 1 M$ & $\begin{array}{l}\text { \$1.625M } \\
\underline{\text { in } 2} \\
\underline{\text { rounds }}\end{array}$ & $\begin{array}{l}\$ 1.63 \\
M / \\
\text { Feb } \\
2015\end{array}$ & Seed & Seed \\
\hline
\end{tabular}




\begin{tabular}{|c|c|c|c|c|c|c|c|}
\hline 7 & $\begin{array}{l}\text { DoorDash, Inc. } \\
\text { I "DoorDash" } \\
\text { www.doordash } \\
\text {.com }\end{array}$ & 2013 & $\$ 4 M$ & $\begin{array}{l}\$ 186.7 \mathrm{M} \\
\text { in } 5 \\
\text { rounds }\end{array}$ & $\begin{array}{l}\$ 127 \mathrm{M} \\
/ \mathrm{Mar} \\
2016\end{array}$ & $\begin{array}{l}\text { Series } \\
\text { C }\end{array}$ & $\begin{array}{l}\text { Late } \\
\text { Stage } \\
\text { Venture }\end{array}$ \\
\hline 8 & $\begin{array}{l}\text { FarmLead } \\
\text { Resources Ltd. } \\
\text { I “Farmlead" } \\
\text { https://farmlea } \\
\underline{\text { d.com }}\end{array}$ & 2013 & $\$ 3.4 \mathrm{M}$ & $\begin{array}{l}\frac{\$ 7.28 \mathrm{M}}{\text { in 2 }} \\
\text { rounds }\end{array}$ & $\begin{array}{l}\$ 6.5 \mathrm{M} \\
\text { / Mar } \\
2017\end{array}$ & $\begin{array}{l}\text { Series } \\
\text { A }\end{array}$ & $\begin{array}{l}\text { Early } \\
\text { Stage } \\
\text { Venture }\end{array}$ \\
\hline 9 & $\begin{array}{l}\text { Guesty, Inc. I } \\
\text { "Guesty" } \\
\text { www.guesty.co } \\
\underline{\underline{m}}\end{array}$ & 2013 & $\$ 1 M$ & $\begin{array}{l}\frac{\$ 4.5 \mathrm{M} \text { in }}{2 \text { rounds }} \\
\underline{2}\end{array}$ & $\begin{array}{l}\$ 3 M / \\
\text { May, } \\
2017\end{array}$ & $\begin{array}{l}\text { Series } \\
\text { A }\end{array}$ & $\begin{array}{l}\text { Early } \\
\text { Stage } \\
\text { Venture }\end{array}$ \\
\hline 10 & $\begin{array}{l}\text { Pillow Homes, } \\
\text { Inc. I "Pillow" } \\
\text { www.pillowho } \\
\underline{\text { mes.com }}\end{array}$ & 2014 & $\$ 2 M$ & $\begin{array}{l}\$ 16.15 \mathrm{M} \\
\text { in } 3 \\
\text { rounds }\end{array}$ & $\begin{array}{l}13.5 \mathrm{M} \\
\text { / Jun } \\
2017\end{array}$ & $\begin{array}{l}\text { Series } \\
\text { A }\end{array}$ & $\begin{array}{l}\text { Early } \\
\text { Stage } \\
\text { Venture }\end{array}$ \\
\hline 11 & $\begin{array}{l}\text { Helpling GmbH } \\
\text { I "Helpling" } \\
\text { www.helpling.d } \\
\underline{\mathrm{e}}\end{array}$ & 2014 & $\$ 19 M$ & $\begin{array}{l}\$ 72.74 \mathrm{M} \\
\text { in } 4 \\
\text { rounds }\end{array}$ & $\begin{array}{l}€ 10 M / \\
\text { Mar } \\
2017\end{array}$ & $\begin{array}{l}\text { Series } \\
\mathrm{C}\end{array}$ & $\begin{array}{l}\text { Status } \\
\text { unknow } \\
n\end{array}$ \\
\hline 12 & $\begin{array}{l}\text { Thrive Market, } \\
\text { Inc. I "Thrive } \\
\text { Market" } \\
\text { www.thrivemar } \\
\text { ket.com }\end{array}$ & 2014 & $\$ 1.3 \mathrm{M}$ & $\frac{\$ 161.88}{\frac{M \text { in } 4}{\text { rounds }}}$ & $\begin{array}{l}\$ 10 M / \\
\text { Oct } \\
2016\end{array}$ & $\begin{array}{l}\text { Conver } \\
\text { ti-ble } \\
\text { note }\end{array}$ & $\begin{array}{l}\text { Early } \\
\text { Stage } \\
\text { Venture }\end{array}$ \\
\hline 13 & $\begin{array}{l}\text { Loop Financial, } \\
\text { Inc. I "Lending } \\
\text { Loop" } \\
\text { www.lendinglo } \\
\underline{\text { op.ca }}\end{array}$ & 2014 & $\$ 1.5 \mathrm{M}$ & $\begin{array}{l}\frac{\$ 12 M \text { in }}{2 \text { rounds }} \\
\underline{2}\end{array}$ & $\begin{array}{l}\$ 10 M / \\
\text { Oct } \\
2017\end{array}$ & $\begin{array}{l}\text { Debt } \\
\text { financi } \\
\text { ng }\end{array}$ & $\begin{array}{l}\text { Status } \\
\text { unknow } \\
n\end{array}$ \\
\hline 14 & $\begin{array}{l}\text { Proov, Inc. I } \\
\text { "prooV" } \\
\text { www.proov.io } \\
\end{array}$ & 2015 & $\$ 4 M$ & $\begin{array}{l}\$ 21 \mathrm{M} \text { in } \\
2 \text { rounds }\end{array}$ & $\begin{array}{l}14 \mathrm{M} / \\
\text { Aug } \\
2017\end{array}$ & $\begin{array}{l}\text { Series } \\
\text { B }\end{array}$ & $\begin{array}{l}\text { Early } \\
\text { Stage } \\
\text { Venture }\end{array}$ \\
\hline
\end{tabular}




\begin{tabular}{|c|c|c|c|c|c|c|c|}
\hline 15 & $\begin{array}{l}\text { Outschool, Inc } \\
\text { | "Outschool" } \\
\text { https://outscho } \\
\underline{\text { ol.com }}\end{array}$ & 2015 & $\$ 2 M$ & $\begin{array}{l}\$ 1.52 \mathrm{M} \\
\text { in } 2 \\
\text { rounds }\end{array}$ & $\begin{array}{l}\$ 1,4 \mathrm{M} / \\
\text { Jun, } \\
2017\end{array}$ & Seed & Seed \\
\hline 16 & $\begin{array}{l}\text { Airsorted } \\
\text { Limited I } \\
\text { "Airsorted" } \\
\text { www.airsorted. } \\
\underline{\mathrm{uk}}\end{array}$ & 2015 & $\$ 1 M$ & $\begin{array}{l}\$ 1.88 \mathrm{M} \\
\text { in } 5 \\
\text { rounds }\end{array}$ & $\begin{array}{l}£ 1.5 \mathrm{M} / \\
\text { Feb, } \\
2017\end{array}$ & Seed & Seed \\
\hline 17 & $\begin{array}{l}\text { Mealpal, Inc. I } \\
\text { “MealPal” } \\
\underline{\text { www.mealpal.c }} \\
\underline{\text { om }}\end{array}$ & 2016 & $\$ 5 M$ & $\begin{array}{l}\$ 35 \mathrm{M} \text { in } \\
2 \text { rounds }\end{array}$ & $\begin{array}{l}\$ 20 M / \\
\text { Sep } \\
2017\end{array}$ & $\begin{array}{l}\text { Series } \\
\text { B }\end{array}$ & $\begin{array}{l}\text { Early } \\
\text { Stage } \\
\text { Venture }\end{array}$ \\
\hline 18 & $\begin{array}{l}\text { MissionU PBC I } \\
\text { “MissionU” } \\
\text { www.missionu. } \\
\underline{\text { com }}\end{array}$ & 2016 & $\$ 1 M$ & $\begin{array}{l}\$ 11.5 \mathrm{M} \\
\text { in } 2 \\
\text { rounds }\end{array}$ & $\begin{array}{l}\$ 8.5 / \\
\text { Sep } \\
2017\end{array}$ & $\begin{array}{l}\text { Series } \\
\text { A }\end{array}$ & $\begin{array}{l}\text { Early } \\
\text { Stage } \\
\text { Venture }\end{array}$ \\
\hline 19 & $\begin{array}{l}\text { Snappr Pty. Ltd. } \\
\text { | "Snappr" } \\
\text { www.snappr.co }\end{array}$ & 2016 & $\$ 1 M$ & $\begin{array}{l}\$ 2.38 \mathrm{M} \\
\text { in } 3 \\
\text { rounds }\end{array}$ & $\begin{array}{l}\text { \$2M / } \\
\text { Sep } \\
2017\end{array}$ & Seed & Seed \\
\hline
\end{tabular}

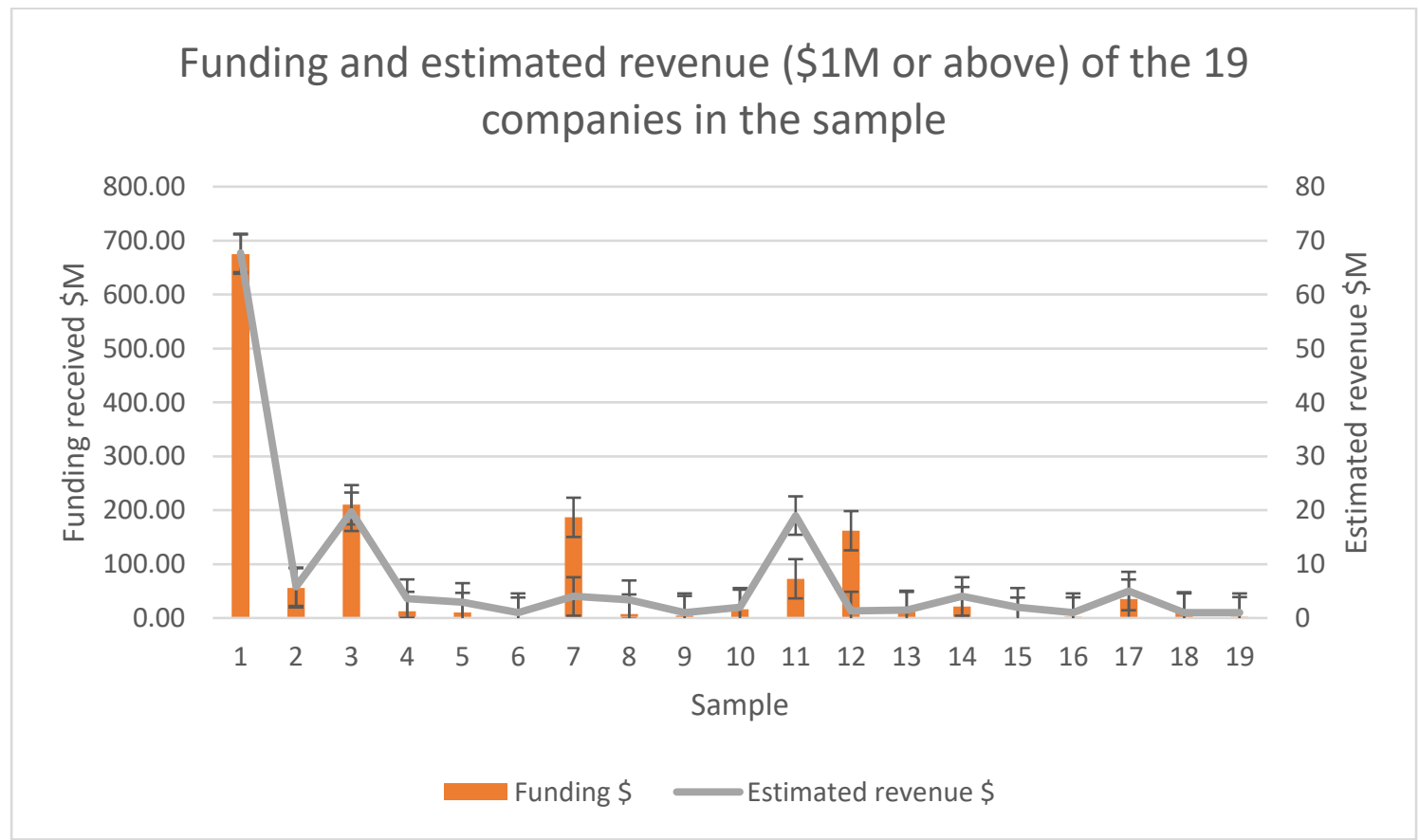


Appendix 2: Data for the three agents and three affiliations collected for 19 companies included in the sample

S1: Instacart (2012) https://www.instacart.com

\begin{tabular}{|c|c|c|}
\hline Direct interaction: & & $\begin{array}{l}\text { grocers sell groceries with a delivery service option to } \\
\text { buyers online }\end{array}$ \\
\hline $\begin{array}{l}\text { Affiliation between } \\
\text { sides }\end{array}$ & $\mathrm{Y}$ & Grocery stores and customers \\
\hline $\begin{array}{l}\text { Independents' platform } \\
\text { specific investment: }\end{array}$ & $Y$ & Grocers issue coupons, promotional offers \\
\hline $\begin{array}{l}\text { Customers' platform } \\
\text { specific investment: }\end{array}$ & $\mathrm{Y}$ & purchase $\$$, delivery cost $\$$, Instacart fee $\$$ \\
\hline $\begin{array}{l}\text { MSP Operator's } \\
\text { platform-specific } \\
\text { investments: }\end{array}$ & $\mathrm{Y}$ & $\begin{array}{l}\text { - } \quad \text { Operates e-commerce platform } \\
\text { - } \quad \text { to Grocers: access to the Instacart framework, } \\
\text { operations, logistics, and user interface, and labor } \\
\text { - a network of shoppers; } \\
\text { - } \quad \text { to Customers: dashboard of storefronts, delivery } \\
\text { by personal shoppers, free delivery on a first } \\
\text { order, regular/ express service option, customized } \\
\text { offers (coupons, promotions), website content } \\
\text { (recopies, lists), mobile app; } \\
\text { - To Shoppers: fees for pick up and delivery } \$\end{array}$ \\
\hline $\begin{array}{l}\text { Independents with } \\
\text { significant information } \\
\text { generating demand: }\end{array}$ & $\mathrm{Y}$ & Grocers, Grocers issue coupons, promotional offers \\
\hline $\begin{array}{l}\text { Large and experienced } \\
\text { buyers: }\end{array}$ & $\mathrm{Y}$ & Customers buying groceries \\
\hline $\begin{array}{l}\text { Product or service: } \\
\text { complementary } \\
\text { products with long } \\
\text { shelf life }\end{array}$ & $\mathrm{Y}$ & complementary products, not resold \\
\hline $\begin{array}{l}\text { Operate feedback } \\
\text { systems: }\end{array}$ & $\mathrm{Y}$ & $\begin{array}{l}\text { Customer feedback | social media | Blog | Shopper } \\
\text { support | contact us }\end{array}$ \\
\hline $\begin{array}{l}\text { Proficient relationships } \\
\text { with independents: }\end{array}$ & $\mathrm{Y}$ & Partner grocers \\
\hline $\begin{array}{l}\text { Leadership roles in } \\
\text { marketing and business } \\
\text { development: }\end{array}$ & & \\
\hline & & \\
\hline
\end{tabular}


S2: Freightos (2012) https://www.freightos.com

\begin{tabular}{|c|c|c|}
\hline Direct interaction: & & $\begin{array}{l}\text { Shippers \& forwarders/carriers generate quotes, } \\
\text { share rates, and find lowest shipping rates \& fastest } \\
\text { routes for e-commerce customers through } \\
\text { Software-as-a-Service platform }\end{array}$ \\
\hline Affiliation between sides & $\mathrm{Y}$ & $\begin{array}{l}\text { Shippers |forwarders/carriers | and e-commerce } \\
\text { retailers }\end{array}$ \\
\hline $\begin{array}{l}\text { Independents' platform } \\
\text { specific investment: }\end{array}$ & $\mathrm{Y}$ & $\begin{array}{l}\text { Shippers' - @2\% of secured order +transaction fee | } \\
\text { forwarders/Carriers' - buy on Freightos } \\
\text { marketplace; book from Freightos vendors | }\end{array}$ \\
\hline $\begin{array}{l}\text { Customers' platform } \\
\text { specific investment: }\end{array}$ & $\mathrm{Y}$ & $\begin{array}{l}\text { e-commerce retailers' - sell on Freightos } \\
\text { marketplace; }\end{array}$ \\
\hline $\begin{array}{l}\text { MSP Operator's } \\
\text { platform-specific } \\
\text { investments: }\end{array}$ & $\mathrm{Y}$ & 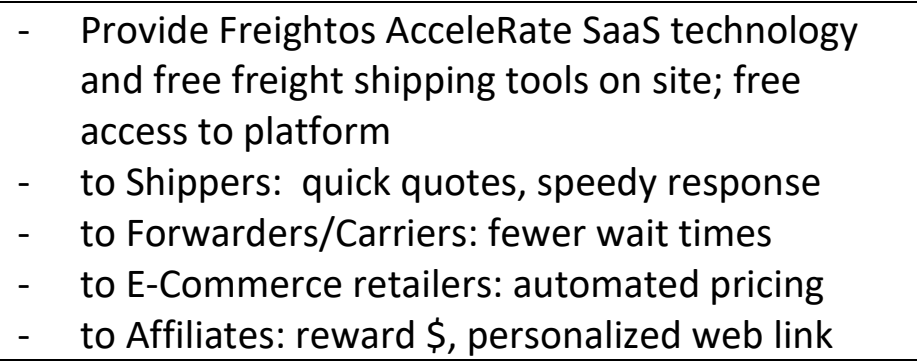 \\
\hline $\begin{array}{l}\text { Independents with } \\
\text { significant information } \\
\text { generating demand: }\end{array}$ & $\mathrm{Y}$ & $\begin{array}{l}\text { Shippers generating quick quotes, speedy responses } \\
\text { using MSP provided tech \& tools }\end{array}$ \\
\hline $\begin{array}{l}\text { Large and experienced } \\
\text { buyers: }\end{array}$ & $\mathrm{Y}$ & e-commerce retailers \\
\hline $\begin{array}{l}\text { Product or service: } \\
\text { complementary } \\
\text { products with long shelf } \\
\text { life }\end{array}$ & $\mathrm{Y}$ & $\begin{array}{l}\text { complementary products with long shelf life; cannot } \\
\text { be resold or reused }\end{array}$ \\
\hline $\begin{array}{l}\text { Operate feedback } \\
\text { systems: }\end{array}$ & $\mathrm{Y}$ & Freight Tools | Social media | Contact us | Events \\
\hline $\begin{array}{l}\text { Proficient relationships } \\
\text { with independents: }\end{array}$ & & \\
\hline $\begin{array}{l}\text { Leadership roles in } \\
\text { marketing and business } \\
\text { development: }\end{array}$ & & \\
\hline
\end{tabular}

S3: Coursera (2012) http://www.coursera.org

\begin{tabular}{|l|l|}
\hline Direct interaction: & $\begin{array}{l}\text { course providers offer courses to a diverse audience } \\
\text { of learners online }\end{array}$ \\
\hline
\end{tabular}




\begin{tabular}{|c|c|c|}
\hline $\begin{array}{l}\text { Affiliation between } \\
\text { sides }\end{array}$ & $Y$ & $\begin{array}{l}\text { Educators/Developers providing courses| Learner } \\
\text { support and Learners }\end{array}$ \\
\hline $\begin{array}{l}\text { Independents' } \\
\text { platform specific } \\
\text { investment: }\end{array}$ & $Y$ & $\begin{array}{l}\text { Educators provide content, facilitate courses; co-brand } \\
\text { certificates; }\end{array}$ \\
\hline $\begin{array}{l}\text { Customers' platform } \\
\text { specific investment: }\end{array}$ & $Y$ & $\begin{array}{l}\text { Learners } \\
-\quad \text { Learn for fee } \$ \text {, audit courses for free; } \\
\text { - } \quad \text { Volunteer as Mentors - foster discussion; } \\
-\quad \text { Volunteer as translators - translate video subtitles }\end{array}$ \\
\hline $\begin{array}{l}\text { MSP Operator's } \\
\text { platform-specific } \\
\text { investments: }\end{array}$ & $Y$ & 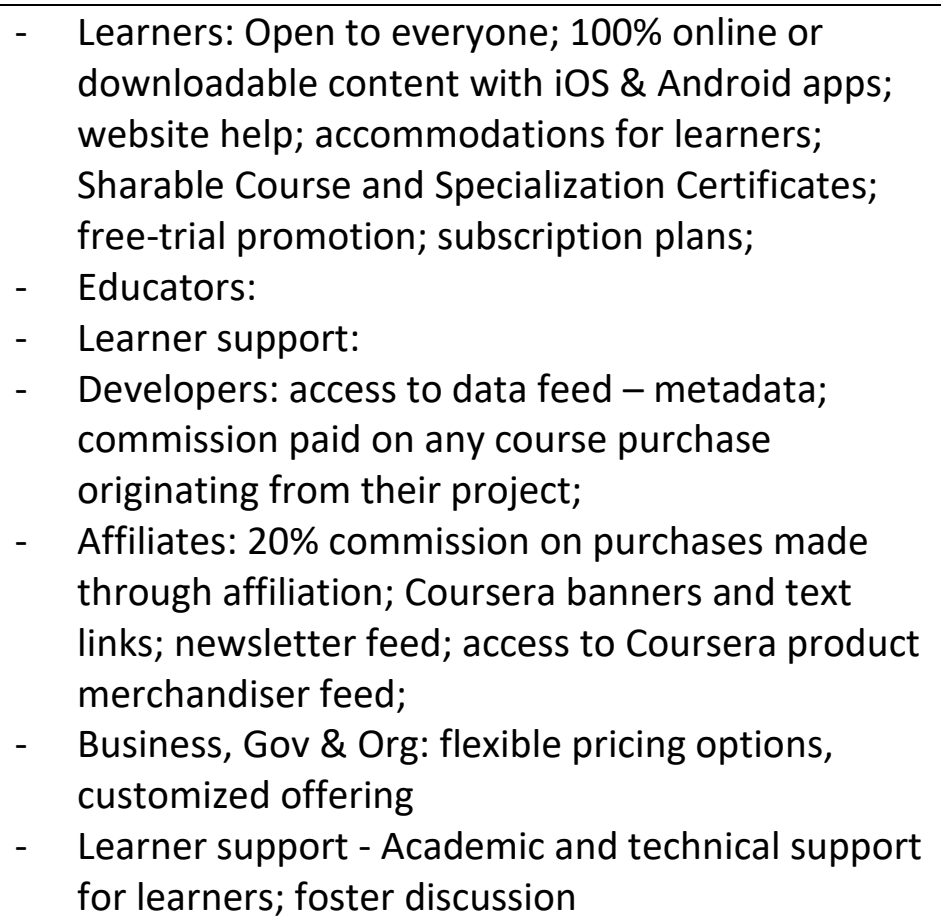 \\
\hline $\begin{array}{l}\text { Independents with } \\
\text { significant information } \\
\text { generating demand: }\end{array}$ & $Y$ & Educators | Developers offer courses \\
\hline $\begin{array}{l}\text { Large and experienced } \\
\text { buyers: }\end{array}$ & $Y$ & Learners \\
\hline $\begin{array}{l}\text { Product or service: } \\
\text { complementary } \\
\text { products with long } \\
\text { shelf life }\end{array}$ & $Y$ & $\begin{array}{l}\text { complementary products with long shelf life; cannot } \\
\text { be resold }\end{array}$ \\
\hline $\begin{array}{l}\text { Operate feedback } \\
\text { systems: }\end{array}$ & $Y$ & $\begin{array}{l}\text { Community Blog | Social media | Course review and } \\
\text { rating | Blog | Contact us }\end{array}$ \\
\hline $\begin{array}{l}\text { Proficient } \\
\text { relationships with } \\
\text { independents: }\end{array}$ & $Y$ & Developers \\
\hline $\begin{array}{l}\text { Leadership roles in } \\
\text { marketing and }\end{array}$ & & \\
\hline
\end{tabular}


business

development:

\section{S4: Cohealo (2012) http://www.cohealo.com}

\begin{tabular}{|c|c|c|}
\hline Direct interaction: & & $\begin{array}{l}\text { health system providers optimize the use of clinical } \\
\text { assets and medical facilities improve access to care by } \\
\text { centralizing clinical assets through a cloud-based } \\
\text { platform }\end{array}$ \\
\hline $\begin{array}{l}\text { Affiliation between } \\
\text { sides }\end{array}$ & $Y$ & Health system providers and Medical facilities \\
\hline $\begin{array}{l}\text { Independents' } \\
\text { platform specific } \\
\text { investment: }\end{array}$ & $\mathrm{Y}$ & $\begin{array}{l}\text { Health systems/Medical institutions' - liberate their } \\
\text { equipment in support of clinical teams across } \\
\text { communities }\end{array}$ \\
\hline $\begin{array}{l}\text { Customers' platform } \\
\text { specific investment: }\end{array}$ & $\mathrm{Y}$ & Medical facilities' - improve access to care \\
\hline $\begin{array}{l}\text { MSP Operator's } \\
\text { platform-specific } \\
\text { investments: }\end{array}$ & $\mathrm{Y}$ & $\begin{array}{l}\text { - Provide cloud-based platform supporting logistics } \\
\text { capabilities, and analytics; centralizes all medical } \\
\text { equipment and its data on one platform to track a } \\
\text { health system's equipment across facilities; access } \\
\text { to data through an intuitive app; } \\
\text { - } \quad \text { Health system providers and medical facilities: On- } \\
\text { demand access to every asset in the system; Alerts } \\
\text { when new technology is added to the system; } \\
\text { benefit from optimized spend, accelerated cash } \\
\text { flow } \\
\text { Medical facilities: customized dashboard; } \\
\text { electronic records to quickly access and locate any } \\
\text { piece of medical equipment; Real-time data and } \\
\text { usage analytics, benefit from optimizing access to } \\
\text { care }\end{array}$ \\
\hline $\begin{array}{l}\text { Independents with } \\
\text { significant information } \\
\text { generating demand: }\end{array}$ & $\mathrm{Y}$ & Health system providers liberate assets, \\
\hline $\begin{array}{l}\text { Large and experienced } \\
\text { buyers: }\end{array}$ & $\mathrm{Y}$ & Medical facilities (patients and clinician) \\
\hline $\begin{array}{l}\text { Product or service: } \\
\text { complementary } \\
\text { products with long } \\
\text { shelf life }\end{array}$ & $\mathrm{Y}$ & $\begin{array}{l}\text { complementary products with long shelf life; cannot } \\
\text { be resold or reused }\end{array}$ \\
\hline $\begin{array}{l}\text { Operate feedback } \\
\text { systems: }\end{array}$ & $\mathrm{Y}$ & Social media | Customer support | chat \\
\hline
\end{tabular}




\begin{tabular}{|l|l|l|}
\hline $\begin{array}{l}\text { Proficient relationships } \\
\text { with independents: }\end{array}$ & & \\
\hline Leadership roles in & & \\
marketing and & & \\
business development: & & \\
\hline & & \\
\hline
\end{tabular}

\section{S5: Ahalogy (2012) http://ahalogy.com}

\begin{tabular}{|c|c|c|}
\hline Direct interaction: & & $\begin{array}{l}\text { Brands \& content creators grow customers and } \\
\text { consumers maximise their experience through } \\
\text { audience insights uncovered using category trend } \\
\text { data }\end{array}$ \\
\hline Affiliation between sides & $\mathrm{Y}$ & Brands \& content creators | Users/Influencers \\
\hline $\begin{array}{l}\text { Independents' platform } \\
\text { specific investment: }\end{array}$ & $\mathrm{Y}$ & $\begin{array}{l}\text { Brands \& content creators - } \$ \text { subscription per } \\
\text { category; }\end{array}$ \\
\hline $\begin{array}{l}\text { Customers' platform } \\
\text { specific investment: }\end{array}$ & $\mathrm{Y}$ & $\begin{array}{l}\text { Users/Influencers' - indirectly, provide category } \\
\text { content data }\end{array}$ \\
\hline $\begin{array}{l}\text { MSP Operator's platform- } \\
\text { specific investments: }\end{array}$ & $\mathrm{Y}$ & $\begin{array}{l}\text { - Deliver category trend data, authentic } \\
\text { influencer content, and social optimization } \\
\text { technology; measurable impressions; provide } \\
\text { third-party tracking; } \\
\text { - Brands \& Agencies: offer MUSE to track } \\
\text { content (free during planning) and } \\
\text { BRANDABLES to uncover audience insights; } \\
\text { Sign up for free + request a demo }\end{array}$ \\
\hline $\begin{array}{l}\text { Independents with } \\
\text { significant information } \\
\text { generating demand: }\end{array}$ & $\mathrm{Y}$ & $\begin{array}{l}\text { Brands \& content creators through engagement } \\
\text { metrics }\end{array}$ \\
\hline $\begin{array}{l}\text { Large and experienced } \\
\text { buyers: }\end{array}$ & $\mathrm{Y}$ & Users/Influencers \\
\hline $\begin{array}{l}\text { Product or service: } \\
\text { complementary products } \\
\text { with long shelf life }\end{array}$ & $\mathrm{Y}$ & complementary products with a long shelf life \\
\hline $\begin{array}{l}\text { Operate feedback } \\
\text { systems: }\end{array}$ & $\mathrm{Y}$ & Social media | contact us \\
\hline $\begin{array}{l}\text { Proficient relationships } \\
\text { with independents: }\end{array}$ & $\mathrm{Y}$ & Influencers \\
\hline $\begin{array}{l}\text { Leadership roles in } \\
\text { marketing and business } \\
\text { development: }\end{array}$ & & \\
\hline & & \\
\hline
\end{tabular}




\section{S6: Exitround (2103) https://exitround.com}

\begin{tabular}{|c|c|c|}
\hline Direct interaction: & & $\begin{array}{l}\text { company founders (sell-side companies) feature } \\
\text { best company exposure and buyers acquire } \\
\text { companies using proprietary software algorithm }\end{array}$ \\
\hline Affiliation between sides & $Y$ & Acquirers | sell-side companies \\
\hline $\begin{array}{l}\text { Independents' platform } \\
\text { specific investment: }\end{array}$ & $Y$ & Sell-side companies - optimization efforts; \\
\hline $\begin{array}{l}\text { Customers' platform } \\
\text { specific investment: }\end{array}$ & $\mathrm{Y}$ & $\begin{array}{l}\text { Acquirers pay } 1 \% \text { of the deal or minimum fee } \\
\$ 20 \mathrm{k} \text { to MSP operator }\end{array}$ \\
\hline $\begin{array}{l}\text { MSP Operator's platform- } \\
\text { specific investments: }\end{array}$ & $\mathrm{Y}$ & $\begin{array}{l}\text { - } \quad \text { proprietary software algorithms (free services } \\
\text { initially); } \\
\text { - } \quad \text { sell-side: feature companies for exposure, } \\
\text { optimize profile, explore opportunities } \\
\text { - } \quad \text { acquirers: ideal match, consultation with } \\
\text { curators } \\
\text { - } \quad \text { curators:? }\end{array}$ \\
\hline $\begin{array}{l}\text { Independents with } \\
\text { significant information } \\
\text { generating demand: }\end{array}$ & $Y$ & Sell-side companies \\
\hline $\begin{array}{l}\text { Large and experienced } \\
\text { buyers: }\end{array}$ & $Y$ & Experienced acquirers \\
\hline $\begin{array}{l}\text { Product or service: } \\
\text { complementary products } \\
\text { with long shelf life }\end{array}$ & $Y$ & complementary products with a long shelf life \\
\hline Operate feedback systems: & $Y$ & Social media | Blog | Contact us \\
\hline \multicolumn{3}{|l|}{$\begin{array}{l}\text { Proficient relationships with } \\
\text { independents: }\end{array}$} \\
\hline $\begin{array}{l}\text { Leadership roles in } \\
\text { marketing and business } \\
\text { development: }\end{array}$ & & \\
\hline & & \\
\hline
\end{tabular}

\section{S7: DoorDash (2013) www.doordash.com}

\begin{tabular}{|l|c|l|}
\hline Direct interaction: & & $\begin{array}{l}\text { businesses sell food and other items and } \\
\text { customers buy and order delivery online }\end{array}$ \\
\hline Affiliation between sides & Y & Restaurant | Dashers / Customers \\
\hline $\begin{array}{l}\text { Independents' platform specific } \\
\text { investment: }\end{array}$ & $Y$ & Restaurants' - (don't know how); \\
\hline $\begin{array}{l}\text { Customers' platform specific } \\
\text { investment: }\end{array}$ & Y & Customers (don't know how) \\
\hline
\end{tabular}




\begin{tabular}{|c|c|c|}
\hline $\begin{array}{l}\text { MSP Operator's platform-specific } \\
\text { investments: }\end{array}$ & $\mathrm{Y}$ & $\begin{array}{l}\text { - } \quad \text { receive orders, directs them to the } \\
\text { restaurant, and assign a dasher } \\
\text { - } \quad \text { Dashers: delivery \$ and perks } \\
\text { - } \quad \text { Restaurants: web interface, mobile } \\
\text { app, delivery logistics, exclusive dasher } \\
\text { service; } \\
\text { - } \quad \text { Customers: delivery status algorithm }\end{array}$ \\
\hline $\begin{array}{l}\text { Independents with significant } \\
\text { information generating demand: }\end{array}$ & $\mathrm{Y}$ & Restaurants (don't know how) \\
\hline Large and experienced buyers: & $\mathrm{Y}$ & Customers \\
\hline $\begin{array}{l}\text { Product or service: } \\
\text { complementary products with } \\
\text { long shelf life }\end{array}$ & $\mathrm{Y}$ & Complementary, cannot be resold \\
\hline Operate feedback systems: & $\mathrm{Y}$ & $\begin{array}{l}\text { Uses "Delight Score" system | Blog | Social } \\
\text { media | support | Glassdoor }\end{array}$ \\
\hline \multicolumn{3}{|l|}{$\begin{array}{l}\text { Proficient relationships with } \\
\text { independents: }\end{array}$} \\
\hline $\begin{array}{l}\text { Leadership roles in marketing and } \\
\text { business development: }\end{array}$ & & \\
\hline
\end{tabular}

S8: FarmLead (2013) https://farmlead.com

\begin{tabular}{|c|c|c|}
\hline Direct interaction: & & $\begin{array}{l}\text { farmers and verified buyers list, negotiate and } \\
\text { finalize grain deals online }\end{array}$ \\
\hline Affiliation between sides & $Y$ & Farmers and grain buyers \\
\hline $\begin{array}{l}\text { Independents' platform } \\
\text { specific investment: }\end{array}$ & $\mathrm{Y}$ & $\begin{array}{l}\text { Farmers' - free to post; increase seller ratings by } \\
\text { adding photos and grain specs sheets; a connection } \\
\text { fee of } \$ 1 / \mathrm{MT} \text { for the first } 80 \mathrm{MT} \text {, and } \$ 0.25 / \mathrm{MT} \text { for } \\
\text { every MT thereafter }\end{array}$ \\
\hline $\begin{array}{l}\text { Customers' platform } \\
\text { specific investment: }\end{array}$ & $Y$ & $\begin{array}{l}\text { Buyers' - a connection fee of } \$ 1 / \mathrm{MT} \text { for the first } \\
80 \mathrm{MT} \text {, and } \$ 0.25 / \mathrm{MT} \text { for every MT thereafter }\end{array}$ \\
\hline $\begin{array}{l}\text { MSP Operator's platform- } \\
\text { specific investments: }\end{array}$ & $Y$ & $\begin{array}{l}\text { MSP' } \\
\text { - Watchlists and notifications; grain tests and } \\
\text { negotiations including basis negotiations; } \\
\text { market analysis, seminars \& conferences; CEO's } \\
\text { daily note on price drivers; } \\
\text { - To farmers: Grain calculator, and access to grain } \\
\text { testing labs - created GrainTests.com }\end{array}$ \\
\hline $\begin{array}{l}\text { Independents with } \\
\text { significant information } \\
\text { generating demand: }\end{array}$ & $\mathrm{Y}$ & Farmers \\
\hline
\end{tabular}




\begin{tabular}{|l|l|l|}
\hline $\begin{array}{l}\text { Large and experienced } \\
\text { buyers: }\end{array}$ & Y & Grain buyers \\
\hline $\begin{array}{l}\text { Product or service: } \\
\text { complementary products } \\
\text { with long shelf life }\end{array}$ & Y & Complementary, with long shelf-life \\
\hline $\begin{array}{l}\text { Operate feedback } \\
\text { systems: }\end{array}$ & Y & $\begin{array}{l}\text { Chat | Contact us | Social media | Events | Support } \\
\text { using intercom }\end{array}$ \\
\hline $\begin{array}{l}\text { Proficient relationships } \\
\text { with independents: }\end{array}$ & & \\
\hline $\begin{array}{l}\text { Leadership roles in } \\
\text { marketing and business } \\
\text { development: }\end{array}$ & & \\
\hline
\end{tabular}

S9: Guesty (2013) www.guesty.com

\begin{tabular}{|c|c|c|}
\hline Direct interaction: & & $\begin{array}{l}\text { property management companies \& Airbnb hosts with } \\
\text { multiple accounts efficiently manage all of their } \\
\text { businesses with guests in one platform through cloud- } \\
\text { based software solution }\end{array}$ \\
\hline $\begin{array}{l}\text { Affiliation between } \\
\text { sides }\end{array}$ & $\mathrm{Y}$ & $\begin{array}{l}\text { Property management companies and Airbnb hosts with } \\
\text { multiple accounts (HOSTS) | Guests }\end{array}$ \\
\hline $\begin{array}{l}\text { Independents' } \\
\text { platform specific } \\
\text { investment: }\end{array}$ & $\mathrm{Y}$ & $\begin{array}{l}\text { HOSTS' - an "Account" to manage multiple properties; a } \\
\text { percentage fee on pre-existing bookings and a } \\
\text { commission charge for new bookings; Options: pay for } \\
\text { PMS software only and receptionist service as an extra, } \\
\text { or in a bundle with receptionist service; extra add-on } \\
\text { services for fee; booking cancellation fee } \$ 3\end{array}$ \\
\hline $\begin{array}{l}\text { Customers' platform } \\
\text { specific investment: }\end{array}$ & $\mathrm{Y}$ & Guests' - cancellation subject to host' cancellation policy \\
\hline $\begin{array}{l}\text { MSP Operator's } \\
\text { platform-specific } \\
\text { investments: }\end{array}$ & $\mathrm{Y}$ & $\begin{array}{l}\text { MSP' } \\
\text { - PRODUCT: property management software; channel } \\
\text { management; unified inbox; automation tools; } \\
\text { powerful reporting; staff management app; } \\
\text { personalized website; payment processing; } 24 / 7 \\
\text { guest communication } \\
\text { - } \quad \text { To hosts: distribute the listings of all major OTAs; } \\
\text { guarantees that owner will never miss a booking and } \\
\text { increases visibility; all information on Guesty } \\
\text { dashboard; Assign and manage entire team's tasks } \\
\text { and work schedule; maximize revenue; centralize } \\
\text { and automate hosts' activities } \\
\text { - One-on-one live demo on request | Academy }\end{array}$ \\
\hline
\end{tabular}




\begin{tabular}{|l|l|l|}
\hline $\begin{array}{l}\text { Independents with } \\
\text { significant } \\
\text { information } \\
\text { generating demand: }\end{array}$ & Y & Hosts \\
\hline $\begin{array}{l}\text { Large and } \\
\text { experienced buyers: }\end{array}$ & Y & Guests \\
\hline $\begin{array}{l}\text { Product or service: } \\
\text { complementary } \\
\text { products with long } \\
\text { shelf life }\end{array}$ & Y & Complementary, long shelf-life \\
\hline $\begin{array}{l}\text { Operate feedback } \\
\text { systems: }\end{array}$ & $Y$ & Contact us | Events | Social media | blog | reviews \\
\hline $\begin{array}{l}\text { Proficient } \\
\text { relationships with } \\
\text { independents: }\end{array}$ & & \\
\hline $\begin{array}{l}\text { Leadership roles in } \\
\text { marketing and } \\
\text { business } \\
\text { development: }\end{array}$ & & \\
\hline
\end{tabular}

S10: Pillow (2014) http://www.pillow.com

\begin{tabular}{|l|l|l|}
\hline Direct interaction: & & $\begin{array}{l}\text { building owners allow compliant, transparent short- } \\
\text { term revenue-shared rentals and residents earn an } \\
\text { extra income with an end-to-end hosting solution } \\
\text { through automated property and guest management } \\
\text { services }\end{array}$ \\
\hline $\begin{array}{l}\text { Affiliation between } \\
\text { sides }\end{array}$ & Y & $\begin{array}{l}\text { Building owners / Property Managers / Residents } \\
\text { Service providers | Renters }\end{array}$ \\
\hline $\begin{array}{l}\text { Independents' platform } \\
\text { specific investment: }\end{array}$ & Y & $\begin{array}{l}\text { Building owners' - agree to allow hosting, } \\
\text { Residents and Property managers' - list vacant } \\
\text { homes; }\end{array}$ \\
\hline $\begin{array}{l}\text { Customers' platform } \\
\text { specific investment: }\end{array}$ & Y & $\begin{array}{l}\text { Residents' - sign up for hosting; share income with } \\
\text { owners; } \\
\text { Renters' - rental charges \$ (side in waiting) }\end{array}$ \\
\hline $\begin{array}{l}\text { MSP Operator's } \\
\text { platform-specific } \\
\text { investments: }\end{array}$ & Y & $\begin{array}{l}\text { MSP' } \\
-\quad \begin{array}{l}\text { automate marketing, guest management, key } \\
\text { exchange, and turnover service; dashboard } \\
\text { summary for unit level detail for entire property } \\
\text { portfolio; Live demo } \\
\text { to building owners: monitor platform usage; } \\
\text { access to reporting dashboards; }\end{array}\end{array}$ \\
\hline
\end{tabular}




\begin{tabular}{|l|l|l|}
\hline & & $\begin{array}{l}- \text { to residents: advocate end-to-end hosting } \\
\text { solution, a full-service solution; }\end{array}$ \\
\hline $\begin{array}{l}\text { Independents with } \\
\text { significant information } \\
\text { generating demand: }\end{array}$ & $\mathrm{Y}$ & Residents and Property Managers by listing space \\
\hline $\begin{array}{l}\text { Large and experienced } \\
\text { buyers: }\end{array}$ & $\mathrm{Y}$ & Short-term rent seekers \\
\hline $\begin{array}{l}\text { Product or service: } \\
\text { complementary } \\
\text { products with long shelf } \\
\text { life }\end{array}$ & $\mathrm{Y}$ & Complementary, with long shelf-life \\
\hline $\begin{array}{l}\text { Operate feedback } \\
\text { systems: }\end{array}$ & $\mathrm{Y}$ & Social media \\
\hline $\begin{array}{l}\text { Proficient relationships } \\
\text { with independents: }\end{array}$ & & \\
\hline $\begin{array}{l}\text { Leadership roles in } \\
\text { marketing and business } \\
\text { development: }\end{array}$ & & \\
\hline
\end{tabular}

\section{S11: Helpling (2014) https://www.helpling.de}

\begin{tabular}{|l|c|l|}
\hline Direct interaction: & & $\begin{array}{l}\text { cleaning aids offer household services and customers } \\
\text { search and book cleaning aids on demand online }\end{array}$ \\
\hline $\begin{array}{l}\text { Affiliation between } \\
\text { sides }\end{array}$ & Y & Cleaners / Customers \\
\hline $\begin{array}{l}\text { Independents' } \\
\text { platform specific } \\
\text { investment: }\end{array}$ & Y & $\begin{array}{l}\text { Cleaners' - accept and manage orders online using } \\
\text { Helpling app; }\end{array}$ \\
\hline $\begin{array}{l}\text { Customers' platform } \\
\text { specific investment: }\end{array}$ & Y & $\begin{array}{l}\text { Customers' - provide cleaning agents; regular cleaning } \\
\text { @ € 13,90 /h; one time cleaning @ € 19,90 /h }\end{array}$ \\
\hline $\begin{array}{l}\text { MSP Operator's } \\
\text { platform-specific } \\
\text { investments: }\end{array}$ & $Y$ & $\begin{array}{l}\text { MSP' } \\
\text { - provide tested and insured cleaning aids; operates } \\
\text { the platform, accepts booking requests; handles }\end{array}$ \\
$\begin{array}{l}\text { Rebookings and cancellations of customers; } \\
\text { Customers: no platform usage fee; cleaning aids } \\
\text { insured against liability, security; good conduct } \\
\text { and the trade license; payments 20\% tax } \\
\text { deductible; arrange special requests with cleaning } \\
\text { staff; priorities checklist; Guide + FAQ } \\
\text { Cleaners: get cleaning jobs in their area; earnings } \\
\text { into their accounts every two weeks; }\end{array}$ \\
\hline
\end{tabular}




\begin{tabular}{|l|l|l|}
\hline $\begin{array}{l}\text { Independents with } \\
\text { significant information } \\
\text { generating demand: }\end{array}$ & Y & Cleaners \\
\hline $\begin{array}{l}\text { Large and experienced } \\
\text { buyers: }\end{array}$ & Y & Customers \\
\hline $\begin{array}{l}\text { Product or service: } \\
\text { complementary } \\
\text { products with long } \\
\text { shelf life }\end{array}$ & Y & Complementary, cannot be resold \\
\hline $\begin{array}{l}\text { Operate feedback } \\
\text { systems: }\end{array}$ & Y & $\begin{array}{l}\text { Blog | Social media | Customer reviews on cleaners | } \\
\text { Feedback on website: common and individual } \\
\text { feedback on cleaners; rating system }\end{array}$ \\
\hline $\begin{array}{l}\text { Proficient relationships } \\
\text { with independents: }\end{array}$ & & \\
\hline $\begin{array}{l}\text { Leadership roles in } \\
\text { marketing and business } \\
\text { development: }\end{array}$ & & \\
\hline
\end{tabular}

\section{S12: Thrive Market (2014) https://thrivemarket.com}

\begin{tabular}{|c|c|c|}
\hline Direct interaction: & & $\begin{array}{l}\text { brands sell healthy foods and natural products at } \\
\text { wholesale prices to members online }\end{array}$ \\
\hline Affiliation between sides & $\mathrm{Y}$ & Brands and Families (+ beneficiary families) \\
\hline $\begin{array}{l}\text { Independents' platform } \\
\text { specific investment: }\end{array}$ & $\mathrm{Y}$ & Brands' - $25-50 \%$ off retail prices \\
\hline $\begin{array}{l}\text { Customers' platform } \\
\text { specific investment: }\end{array}$ & $\mathrm{Y}$ & $\begin{array}{l}\text { Families' - Annual membership } \$ 59.95 \text {. donate } \\
\text { from savings at the checkout for a beneficiary's } \\
\text { cart; }\end{array}$ \\
\hline $\begin{array}{l}\text { MSP Operator's platform- } \\
\text { specific investments: }\end{array}$ & $\mathrm{Y}$ & $\begin{array}{l}\text { MSP' - wholesale prices, and to sponsor free } \\
\text { memberships; offer custom educational content; } \\
\text { - } \quad \text { To families: free } 30 \text {-day membership trial; } \\
\text { register for free, } 15 \% \text { off the first purchase; } \\
\text { annual membership - } 20 \% \text { off first } 3 \\
\text { purchases; orders over } \$ 49 \text { ships free; } \\
\text { - } \quad \text { To beneficiary families: free membership; } \\
\text { - } \quad \text { Affiliate partners: } \$ 25 \text { for introducing a friend; } \\
\text { a custom link, sample posts, banners, and } \\
\text { images; a secure account with a dashboard to } \\
\text { track progress } \\
\text { - Free trial + Guide + FAQ }\end{array}$ \\
\hline
\end{tabular}




\begin{tabular}{|l|l|l|}
\hline $\begin{array}{l}\text { Independents with } \\
\text { significant information } \\
\text { generating demand: }\end{array}$ & Y & Brands \\
\hline $\begin{array}{l}\text { Large and experienced } \\
\text { buyers: }\end{array}$ & Y & Families \\
\hline $\begin{array}{l}\text { Product or service: } \\
\text { complementary products } \\
\text { with long shelf life }\end{array}$ & Y & Complementary, cannot be resold \\
\hline $\begin{array}{l}\text { Operate feedback } \\
\text { systems: }\end{array}$ & Y & Contact us | Social media | Blog | Chat \\
\hline $\begin{array}{l}\text { Proficient relationships } \\
\text { with independents: }\end{array}$ & & \\
\hline $\begin{array}{l}\text { Leadership roles in } \\
\text { marketing and business } \\
\text { development: }\end{array}$ & & \\
\hline
\end{tabular}

\section{S13: Lending Loop (2014) www.lendingloop.ca}

\begin{tabular}{|c|c|c|}
\hline Direct interaction: & & $\begin{array}{l}\text { lenders risk managed lending and small businesses } \\
\text { affordable financing through online process }\end{array}$ \\
\hline Affiliation between sides & $\mathrm{Y}$ & Small businesses and Lenders \\
\hline $\begin{array}{l}\text { Independents' platform } \\
\text { specific investment: }\end{array}$ & $\mathrm{Y}$ & $\begin{array}{l}\text { Business' - origination fee }+ \text { interests rates } \\
\text { depending on credit ratings; commitment of } \$ 25 \text { for } \\
\text { returned payment, and } 15 \% \text { of outstanding amount } \\
\text { for late payments beyond } 7 \text { days }\end{array}$ \\
\hline $\begin{array}{l}\text { Customers' platform } \\
\text { specific investment: }\end{array}$ & $\mathrm{Y}$ & $\begin{array}{l}\text { Lenders' - minimum } \$ 200 \text { purchase of securities } \\
\text { (notes); } 1.5 \% \text { annual servicing fee repayments; } \\
\text { commitment to loans in } \$ 25 \text { incremental; connect } \\
\text { QuickBooks account for auto uploading; }\end{array}$ \\
\hline $\begin{array}{l}\text { MSP Operator's } \\
\text { platform-specific } \\
\text { investments: }\end{array}$ & $\mathrm{Y}$ & $\begin{array}{l}\text { MSP' } \\
\text { - } \quad \text { assess lender's investor preferences and risk } \\
\text { tolerance, investment objectives and current } \\
\text { financial position; evaluate the loan request, } \\
\text { assign risk rating, to creditworthy borrowers; } \\
\text { - } \quad \text { For lenders: deposit monthly payments } \\
\text { collected from borrowers; } \\
\text { - } \quad \text { For borrowers: “borrower's Guide” } \\
\text { - } \quad \text { For partners: Distributor Ps - provide for their } \\
\text { clients LL services; Referral Ps - commission; } \\
\text { Affiliate Ps - commission; Vendor Ps - sales; } \\
\text { - Refer a lender: \$25 }\end{array}$ \\
\hline
\end{tabular}




\begin{tabular}{|l|l|l|}
\hline $\begin{array}{l}\text { Independents with } \\
\text { significant information } \\
\text { generating demand: }\end{array}$ & Y & Businesses \\
\hline $\begin{array}{l}\text { Large and experienced } \\
\text { buyers: }\end{array}$ & $\mathrm{Y}$ & Lenders \\
\hline $\begin{array}{l}\text { Product or service: } \\
\text { complementary products } \\
\text { with long shelf life }\end{array}$ & & Complementary, long shelf-life \\
\hline $\begin{array}{l}\text { Operate feedback } \\
\text { systems: }\end{array}$ & $\mathrm{Y}$ & Blog | Social media | Contact us | File complaint \\
\hline $\begin{array}{l}\text { Proficient relationships } \\
\text { with independents: }\end{array}$ & & \\
\hline $\begin{array}{l}\text { Leadership roles in } \\
\text { marketing and business } \\
\text { development: }\end{array}$ & & \\
\hline
\end{tabular}

S14: prooV (2015) http://proov.io

\begin{tabular}{|l|l|l|}
\hline Direct interaction: & & $\begin{array}{l}\text { startups and enterprises facilitate proof-of-Concept } \\
\text { process through Pilot-as-a-service platform }\end{array}$ \\
\hline $\begin{array}{l}\text { Affiliation between } \\
\text { sides }\end{array}$ & Y & Enterprises and Startups \\
\hline $\begin{array}{l}\text { Independents' } \\
\text { platform specific } \\
\text { investment: }\end{array}$ & Y & $\begin{array}{l}\text { Startups' - provide access to testing environment, } \\
\text { maintain accuracy, quality, and legality }\end{array}$ \\
\hline $\begin{array}{l}\text { Customers' platform } \\
\text { specific investment: }\end{array}$ & Y & $\begin{array}{l}\text { Enterprises' - provide access to testing environment, } \\
\text { perform at least one POC during six months, facilitating } \\
\text { POC through the Platform - free of charge; fees for } \\
\text { additional services - KPI suites, predictive analyses }\end{array}$ \\
\hline $\begin{array}{l}\text { MSP Operator's } \\
\text { platform-specific } \\
\text { investments: }\end{array}$ & Y & $\begin{array}{l}\text { MSP' } \\
\text { - Provide Pilot-as-a-Service platform - to facilitate } \\
\text { PoC's; provide License to access and use the } \\
\text { services; various data sets; } \\
\text { Enterprises: access to pre-screened startups/ ISVs } \\
\text { and PoC opportunities; } \\
\text { Startups: Access to PoC ready enterprises and } \\
\text { everything needed to run a winning PoC - RFPs, } \\
\text { APIs, data, systems, etc.; dedicated company } \\
\text { profile page; Enterprise's complete system specs; } \\
\text { Direct chat channel; Remote connection to the } \\
\text { testing environment }\end{array}$ \\
\hline
\end{tabular}




\begin{tabular}{|l|l|l|}
\hline $\begin{array}{l}\text { Independents with } \\
\text { significant } \\
\text { information } \\
\text { generating demand: }\end{array}$ & Y & Startups \\
\hline $\begin{array}{l}\text { Large and } \\
\text { experienced buyers: }\end{array}$ & $\mathrm{Y}$ & Enterprises \\
\hline $\begin{array}{l}\text { Product or service: } \\
\text { complementary } \\
\text { products with long } \\
\text { shelf life }\end{array}$ & $\mathrm{Y}$ & Complementary, cannot be resold \\
\hline $\begin{array}{l}\text { Operate feedback } \\
\text { systems: }\end{array}$ & $\mathrm{Y}$ & Events | Contact us | Social media | Blog \\
\hline $\begin{array}{l}\text { Proficient } \\
\text { relationships with } \\
\text { independents: }\end{array}$ & & \\
\hline $\begin{array}{l}\text { Leadership roles in } \\
\text { marketing and } \\
\text { business } \\
\text { development: }\end{array}$ & & \\
\hline
\end{tabular}

S15: Outschool (2015) https://outschool.com

\begin{tabular}{|c|c|c|}
\hline Direct interaction: & & $\begin{array}{l}\text { teachers offer and sell virtual classes and parents (on } \\
\text { behalf of children) find, book and pay for classes } \\
\text { online }\end{array}$ \\
\hline $\begin{array}{l}\text { Affiliation between } \\
\text { sides }\end{array}$ & $Y$ & Teachers | Learners (parents) \\
\hline $\begin{array}{l}\text { Independents' platform } \\
\text { specific investment: }\end{array}$ & $\mathrm{Y}$ & $\begin{array}{l}\text { Teachers' - determine their class offerings; market, } \\
\text { sell and conduct their Classes; obtain all licenses and } \\
\text { permissions required; agree on revenue rules }\end{array}$ \\
\hline $\begin{array}{l}\text { Customers' platform } \\
\text { specific investment: }\end{array}$ & $\mathrm{Y}$ & $\begin{array}{l}\text { Parents' - find and book Classes; pay all applicable } \\
\text { fees for Classes; post public reviews about classes }\end{array}$ \\
\hline $\begin{array}{l}\text { MSP Operator's } \\
\text { platform-specific } \\
\text { investments: }\end{array}$ & $\mathrm{Y}$ & $\begin{array}{l}\text { MSP' } \\
\text { - } \quad \text { the availability of the Site; serve as the limited } \\
\text { agent of each Teacher for accepting payments } \\
\text { from a Parent; reject, remove any Classes from } \\
\text { the marketplace, edit the class description; } \\
\text { screen teachers; Video + FAQ } \\
\text { - } \quad \text { teachers: transfer the Teacher Fees to their } \\
\text { Paypal account; } \\
\text { - parents: act on behalf of the Parent, for the } \\
\text { adequacy and satisfactory service by teachers }\end{array}$ \\
\hline
\end{tabular}




\begin{tabular}{|l|l|l|}
\hline $\begin{array}{l}\text { Independents with } \\
\text { significant information } \\
\text { generating demand: }\end{array}$ & Y & Teachers \\
\hline $\begin{array}{l}\text { Large and experienced } \\
\text { buyers: }\end{array}$ & $\mathrm{Y}$ & Parents of the learners \\
\hline $\begin{array}{l}\text { Product or service: } \\
\text { complementary } \\
\text { products with long shelf } \\
\text { life }\end{array}$ & $\mathrm{Y}$ & Complementary, cannot be resold \\
\hline $\begin{array}{l}\text { Operate feedback } \\
\text { systems: }\end{array}$ & $\mathrm{Y}$ & $\begin{array}{l}\text { Social media | Contact us | Parents' reviews on } \\
\text { classes | direct contact with teachers | Support using } \\
\text { intercom }\end{array}$ \\
\hline $\begin{array}{l}\text { Proficient relationships } \\
\text { with independents: }\end{array}$ & & \\
\hline $\begin{array}{l}\text { Leadership roles in } \\
\text { marketing and business } \\
\text { development: }\end{array}$ & & \\
\hline
\end{tabular}

S16: Airsorted (2015) www.airsorted.uk

\begin{tabular}{|c|c|c|}
\hline Direct interaction: & & $\begin{array}{l}\text { Home owners let their homes to guests without } \\
\text { being a host }\end{array}$ \\
\hline $\begin{array}{l}\text { Affiliation between } \\
\text { sides }\end{array}$ & $\mathrm{Y}$ & Hosts and Guests \\
\hline $\begin{array}{l}\text { Independents' platform } \\
\text { specific investment: }\end{array}$ & $\mathrm{Y}$ & $\begin{array}{l}\text { Hosts' - } 12 \%+V A T \text { commission to MSP on the rental, } \\
\text { or agree to a guaranteed monthly rent from MSP }\end{array}$ \\
\hline $\begin{array}{l}\text { Customers' platform } \\
\text { specific investment: }\end{array}$ & $\mathrm{Y}$ & Guests' - pay rent for the stay \\
\hline $\begin{array}{l}\text { MSP Operator's } \\
\text { platform-specific } \\
\text { investments: }\end{array}$ & $\mathrm{Y}$ & $\begin{array}{l}\text { MSP' } \\
\text { - Hosts: home inspection, lockbox, listing creation: } \\
\text { professional photography and SEO; organize } \\
\text { professional cleaners, linens, and towels; Guest } \\
\text { vetting; account management; price optimization } \\
\text { - Guests: guest communication; } 24 \mathrm{hrs} \mathrm{check-in;} \\
\text { replenishments; provide cleaning service; }\end{array}$ \\
\hline $\begin{array}{l}\text { Independents with } \\
\text { significant information } \\
\text { generating demand: }\end{array}$ & $\mathrm{Y}$ & MSP on behalf of Hosts \\
\hline $\begin{array}{l}\text { Large and experienced } \\
\text { buyers: }\end{array}$ & $\mathrm{Y}$ & Guests \\
\hline
\end{tabular}




\begin{tabular}{|l|l|l|}
\hline $\begin{array}{l}\text { Product or service: } \\
\text { complementary } \\
\text { products with long shelf }\end{array}$ & Y & Complementary, long shelf-life \\
life
\end{tabular}

S17: MealPal (2016) www.mealpal.com

\begin{tabular}{|c|c|c|}
\hline Direct interaction: & & $\begin{array}{l}\text { restaurants offer monthly subscription } \\
\text { meal plans to members online }\end{array}$ \\
\hline Affiliation between sides & $\mathrm{Y}$ & Restaurants and members \\
\hline $\begin{array}{l}\text { Independents' platform specific } \\
\text { investment: }\end{array}$ & $\mathrm{Y}$ & $\begin{array}{l}\text { Restaurants' - gift cards, commitment to } \\
\text { offer a signature dish daily; }\end{array}$ \\
\hline $\begin{array}{l}\text { Customers' platform specific } \\
\text { investment: }\end{array}$ & $\mathrm{Y}$ & Members' - Membership Fees \\
\hline $\begin{array}{l}\text { MSP Operator's platform-specific } \\
\text { investments: }\end{array}$ & Y & $\begin{array}{l}\text { MSP' - subscription meal plans for }<\$ 6 \\
\text { per meal; promotional plans, trial } \\
\text { membership }\end{array}$ \\
\hline $\begin{array}{l}\text { Independents with significant } \\
\text { information generating demand: }\end{array}$ & $\mathrm{Y}$ & Restaurants \\
\hline Large and experienced buyers: & $\mathrm{Y}$ & $\begin{array}{l}\text { People who need to buy meals almost } \\
\text { every day }\end{array}$ \\
\hline $\begin{array}{l}\text { Product or service: complementary } \\
\text { products with long shelf life }\end{array}$ & $\mathrm{Y}$ & Complementary, cannot be resold \\
\hline Operate feedback systems: & $\mathrm{Y}$ & Social media | Contact us \\
\hline \multicolumn{3}{|l|}{$\begin{array}{l}\text { Proficient relationships with } \\
\text { independents: }\end{array}$} \\
\hline $\begin{array}{l}\text { Leadership roles in marketing and } \\
\text { business development: }\end{array}$ & & \\
\hline
\end{tabular}


S18: MissionU (2016) https:www.missionu.com

\begin{tabular}{|c|c|c|}
\hline Direct interaction: & & $\begin{array}{l}\text { Instructors \& industry experts facilitate industry } \\
\text { informed curriculum based learning to students } \\
\text { through live sessions online }\end{array}$ \\
\hline Affiliation between sides & $\mathrm{Y}$ & $\begin{array}{l}\text { Students | Experts | Academics | Employers (side } \\
\text { in waiting) }\end{array}$ \\
\hline $\begin{array}{l}\text { Independents' platform } \\
\text { specific investment: }\end{array}$ & $\mathrm{Y}$ & $\begin{array}{l}\text { Experts \& Academics' - teach, craft curriculum; } \\
\text { Employers' - real time projects for students }\end{array}$ \\
\hline $\begin{array}{l}\text { Customers' platform } \\
\text { specific investment: }\end{array}$ & $\mathrm{Y}$ & $\begin{array}{l}\text { Students' - ex-post contribution of } 15 \% \text { of their } \\
\text { income for } 3 \text { years }\end{array}$ \\
\hline $\begin{array}{l}\text { MSP Operator's platform- } \\
\text { specific investments: }\end{array}$ & $\mathrm{Y}$ & $\begin{array}{l}\text { MSP' } \\
\text { - } \quad \text { uniquely immersive, collaborative, and efficient } \\
\text { learning experience, industry informed } \\
\text { curriculum; } \\
\text { - } \quad \text { students: in-person activities, structured } \\
\text { projects, team projects, technical skills, work } \\
\text { experience, resume build \& career launch; } \\
\text { Program + sign up | How to apply } \\
\text { - } \quad \text { experts \& Academics:? } \\
\text { - } \quad \text { Ambassadors: cash back bonus for referrals } \\
\text { - } \quad \text { Employers: get access to graduates }\end{array}$ \\
\hline $\begin{array}{l}\text { Independents with } \\
\text { significant information } \\
\text { generating demand: }\end{array}$ & $\mathrm{Y}$ & Experts: MSP: MissionU process \\
\hline $\begin{array}{l}\text { Large and experienced } \\
\text { buyers: }\end{array}$ & $Y$ & Students \\
\hline $\begin{array}{l}\text { Product or service: } \\
\text { complementary products } \\
\text { with long shelf life }\end{array}$ & $Y$ & Complementary, cannot be resold \\
\hline $\begin{array}{l}\text { Operate feedback } \\
\text { systems: }\end{array}$ & $\mathrm{Y}$ & Social media | though hot jar | Contact us \\
\hline $\begin{array}{l}\text { Proficient relationships } \\
\text { with independents: }\end{array}$ & $\mathrm{Y}$ & Partner companies | Employers \\
\hline $\begin{array}{l}\text { Leadership roles in } \\
\text { marketing and business } \\
\text { development: }\end{array}$ & & \\
\hline & & \\
\hline
\end{tabular}

S19: Snappr (2016) www.snappr.co

\begin{tabular}{|l|l|l|l}
\hline Direct interaction: & $\begin{array}{l}\text { photographers offer onsite services and customers } \\
\text { book pre-vetted on demand photographers online }\end{array}$ \\
\hline
\end{tabular}




\begin{tabular}{|c|c|c|}
\hline $\begin{array}{l}\text { Affiliation between } \\
\text { sides }\end{array}$ & $\mathrm{Y}$ & Photographers and subjects (customers) \\
\hline $\begin{array}{l}\text { Independents' } \\
\text { platform specific } \\
\text { investment: }\end{array}$ & $\mathrm{Y}$ & $\begin{array}{l}\text { Photographers' - Snappr fee \$; complete the shoot, } \\
\text { submit the edited photos, and get paid; must own } \\
\text { professional level equipment; } 12 \text { months of Non- } \\
\text { Circumvention Period @ opt-out fee of USD5,000 }\end{array}$ \\
\hline $\begin{array}{l}\text { Customers' platform } \\
\text { specific investment: }\end{array}$ & $\mathrm{Y}$ & Customers' - register with Snappr; full payment upfront \\
\hline $\begin{array}{l}\text { MSP Operator's } \\
\text { platform-specific } \\
\text { investments: }\end{array}$ & $\mathrm{Y}$ & $\begin{array}{l}\text { MSP' - facilitate the availability of the Site; serve as the } \\
\text { limited agent of each Photographer for the purpose of } \\
\text { accepting payments from customer; } \\
\text { - } \quad \text { Photographers: fortnightly payments; provide } \\
\text { insurance for all bookings, photography equipment } \\
\text { theft-damage-loss, public liability and professional } \\
\text { indemnity (in Australia); } \\
\text { - Customers: option to choose photographers; } \\
\text { discounts for bulk purchases; full copyright } \\
\text { ownership; receive photos online within } 3 \text { days, 7- } \\
10 \text { days on print; can book up to } 12 \text { hours in } \\
\text { advance; act on behalf of the Subject for } \\
\text { satisfactory service by the photographer; How it } \\
\text { works + FAQ }\end{array}$ \\
\hline $\begin{array}{l}\text { Independents with } \\
\text { significant } \\
\text { information } \\
\text { generating demand: }\end{array}$ & $\mathrm{Y}$ & pre-vetted pro photographers \\
\hline $\begin{array}{l}\text { Large and } \\
\text { experienced buyers: }\end{array}$ & $\mathrm{Y}$ & Customers who need photographing occasions \\
\hline $\begin{array}{l}\text { Product or service: } \\
\text { complementary } \\
\text { products with long } \\
\text { shelf life }\end{array}$ & $Y$ & Complementary, long shelf-life \\
\hline $\begin{array}{l}\text { Operate feedback } \\
\text { systems: }\end{array}$ & $\mathrm{Y}$ & $\begin{array}{l}\text { Social media | contact photography expert | chat | } \\
\text { google review | Contact us }\end{array}$ \\
\hline \multicolumn{3}{|l|}{$\begin{array}{l}\text { Proficient } \\
\text { relationships with } \\
\text { independents: }\end{array}$} \\
\hline $\begin{array}{l}\text { Leadership roles in } \\
\text { marketing and } \\
\text { business } \\
\text { development: }\end{array}$ & & \\
\hline & & \\
\hline
\end{tabular}


Appendix 3: evidentiary data to findings on relationships among three main agents and each of the new agents for the 19 companies included in the sample

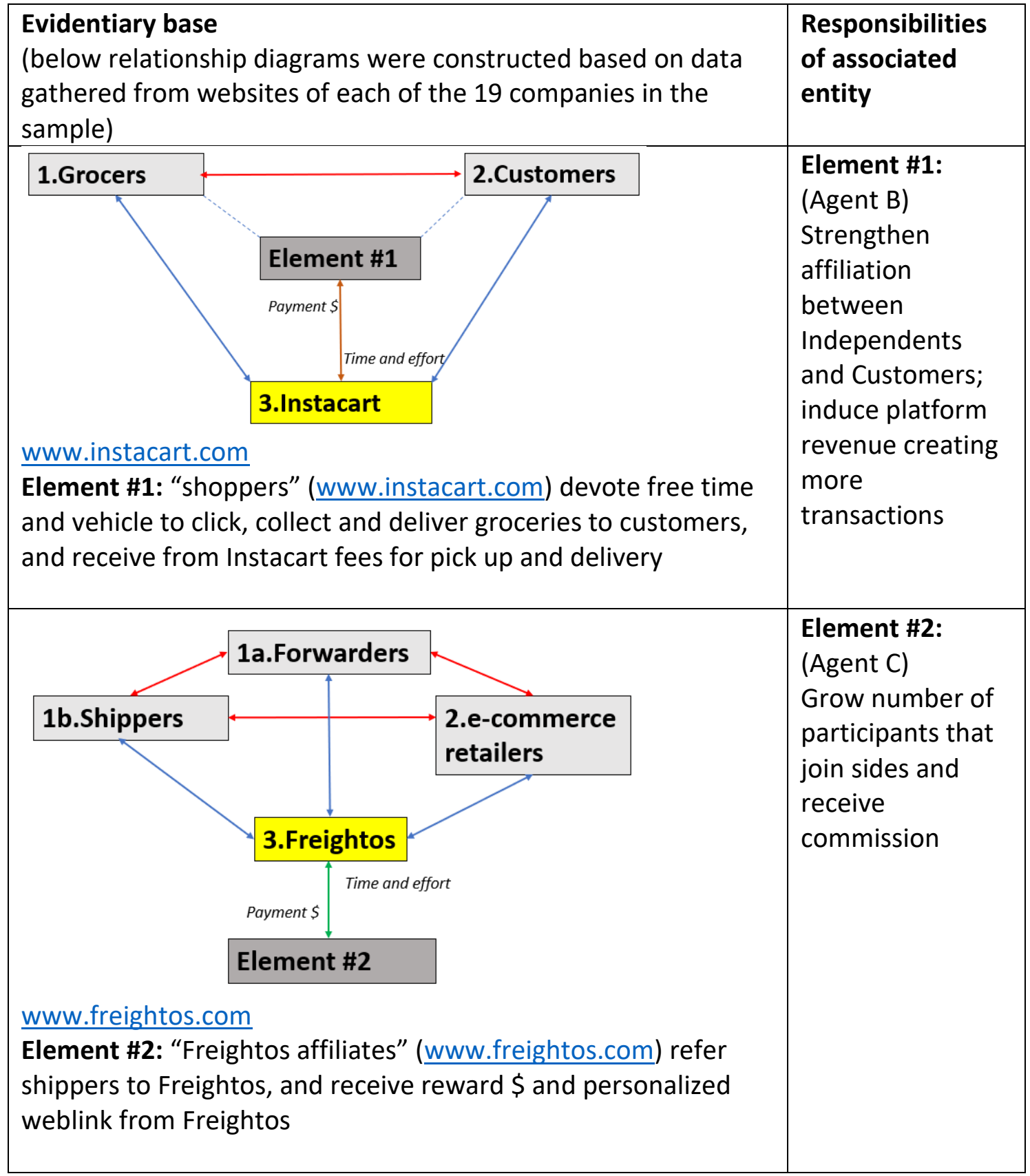




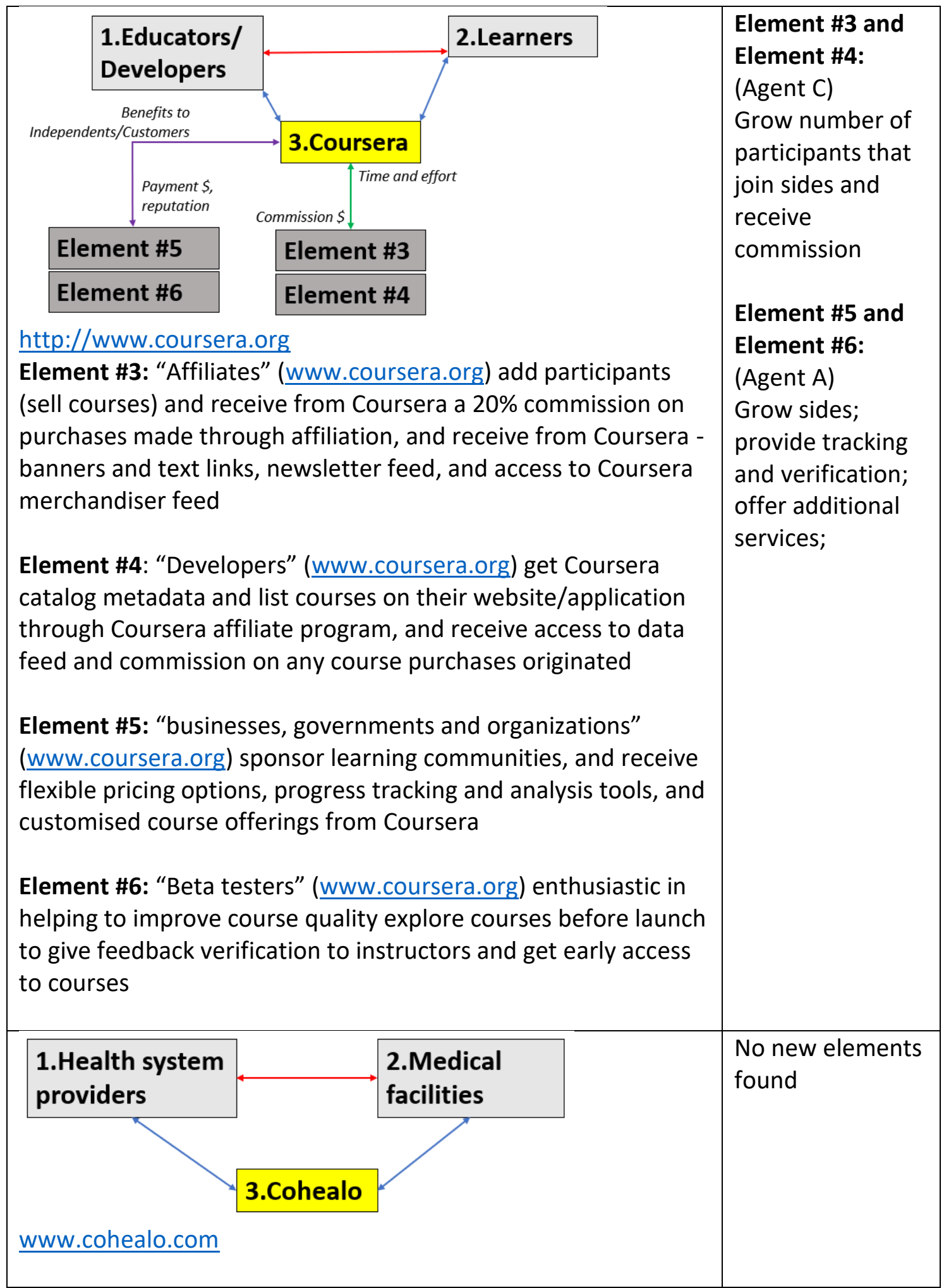




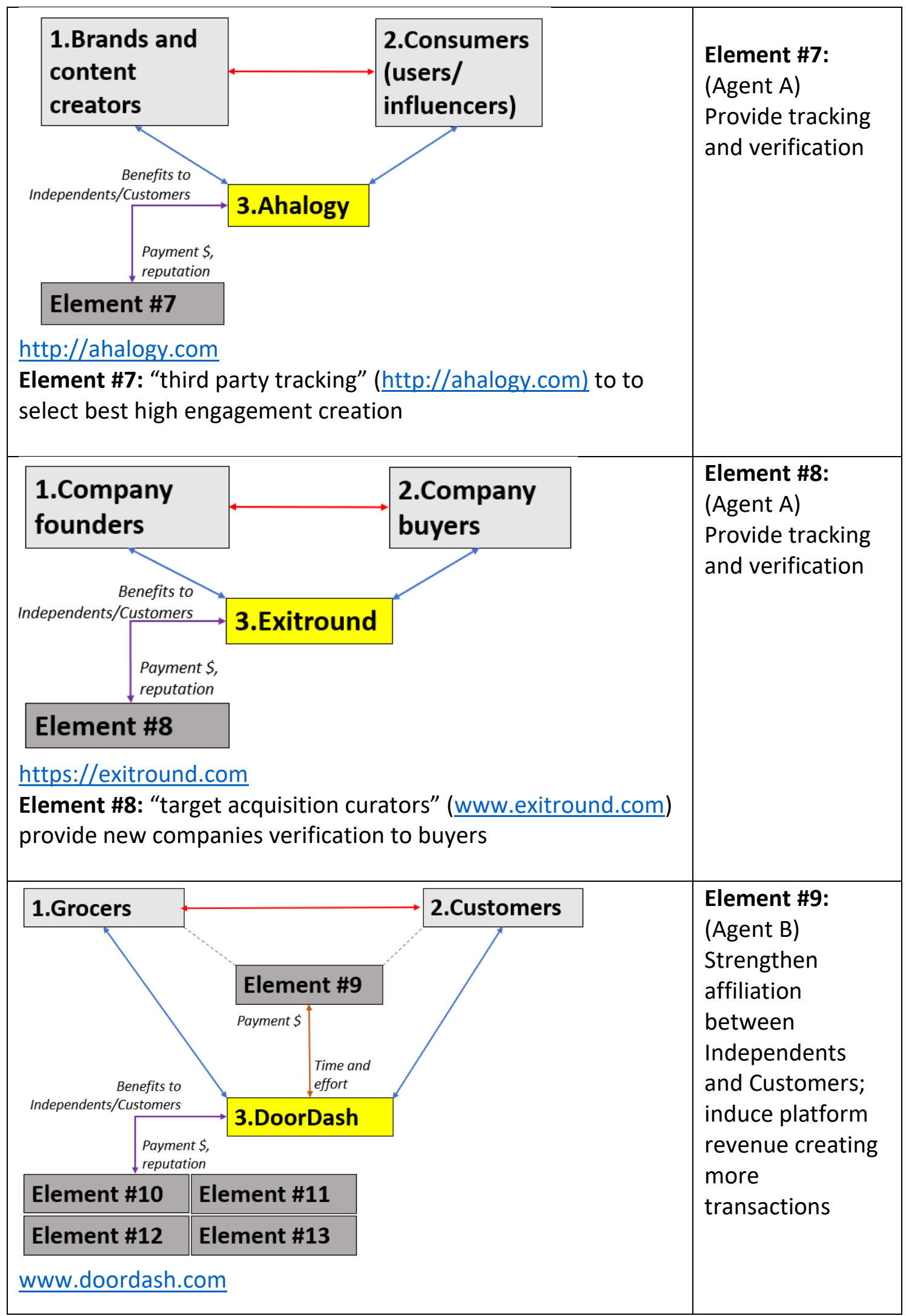




\begin{tabular}{|c|c|}
\hline $\begin{array}{l}\text { Element \#9: "Dashers" (www.doordash.com) devote free time } \\
\text { and vehicle to pick up and deliver groceries and other goods; } \\
\text { receives fees for delivery from DoorDash and other amenities } \\
\text { through connected companies } \\
\text { Element \#10: provide amenities - auto insurance to "Dashers" } \\
\text { Element \#11: provide amenities - health coverage to "Dashers" } \\
\text { Element \#12: provide amenities - everlance app to "Dashers" } \\
\text { for revenue and expenses tracking } \\
\text { Element \#13: provide amenities - daily pay membership at a } \\
\text { concession rate to "Dashers" }\end{array}$ & $\begin{array}{l}\text { Element \#10, } \\
\text { Element \#11, } \\
\text { Element \#12 and } \\
\text { Element \#13: } \\
\text { (Agent A) } \\
\text { Provide amenities } \\
\text { to attract and } \\
\text { retain "Dashers"; }\end{array}$ \\
\hline 1.Farmers & \multirow[t]{2}{*}{$\begin{array}{l}\text { Element \#14 and } \\
\text { Element \#15: } \\
\text { (Agent A) } \\
\text { Handle regulatory } \\
\text { and compliance; } \\
\text { offer additional } \\
\text { services }\end{array}$} \\
\hline $\begin{array}{l}\text { https://farmlead.com } \\
\text { Element \#14: provide buyers verification and credit checks } \\
\text { Element \#15: "Grain testing labs" (www.farmlead.com) to test } \\
\text { grains for quality }\end{array}$ & \\
\hline $\begin{array}{l}\text { 1.Property mgmt. } \\
\text { companies, } \\
\text { Airbnb hosts }\end{array}$ & $\begin{array}{l}\text { No new elements } \\
\text { found }\end{array}$ \\
\hline
\end{tabular}




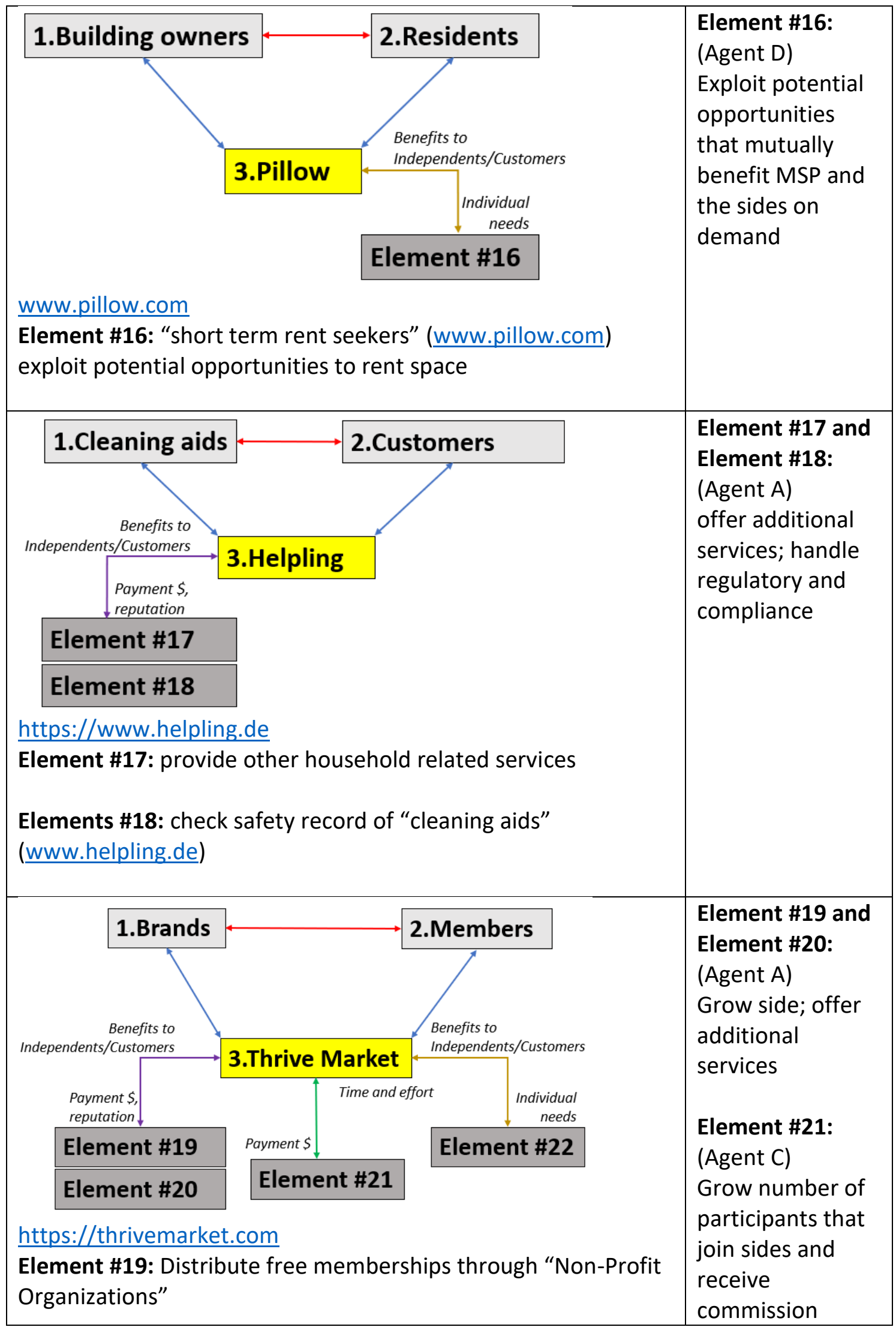


Element \#20: parties that help advocacy campaigns

Element \#22:

(Agent D)

Element \#21: parties that spread the word to drive members and receive from Thrive Market bonus \$, a custom web link, sample posts, banners and images, and a secure account with progress dashboard

Element \#22: "potential recipients of free memberships" a list of families

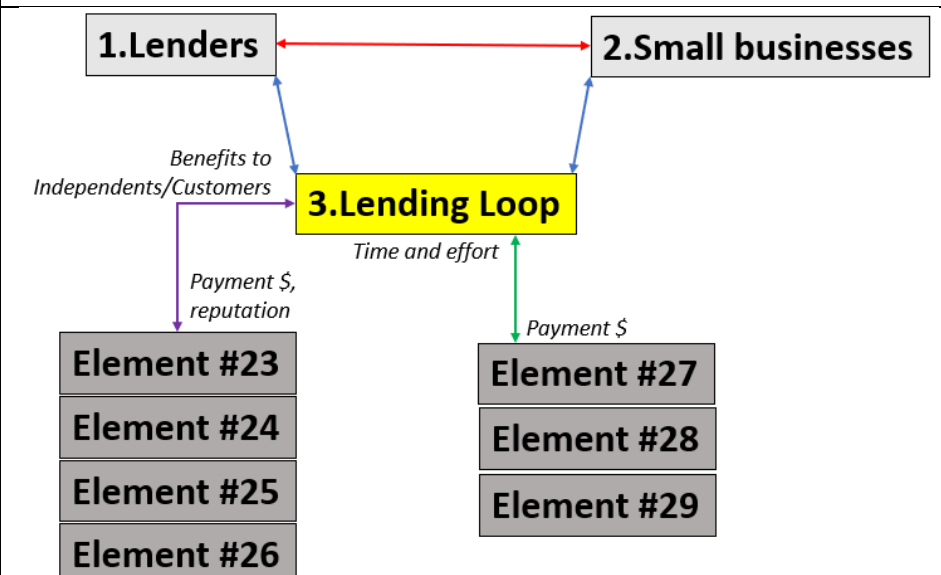

www.lendingloop.ca

Element \#23: "Distributor partners" (www.lendingloop.ca) introduce their clients to Lending Loop services

Element \#24: "Vendor partners" (www.lendingloop.ca) sell products to businesses through Lending Loop financing

Element \#25: provide regulatory compliance through "Canadian Charted Bank" (www.lendingloop.ca) to handle all money that is stored through platform

Element \#26: provide compliance by registering as an "Exempt Market Dealer" (www.lendingloop.ca) in all provinces and territories

Element \#27: "Referral partners" (www.lendingloop.ca) refer business owners to Lending Loop and receive commission

Element \#28: "Affiliate partners" (www.lendingloop.ca) publish content and refer readers to Lending Loop and receive commission 


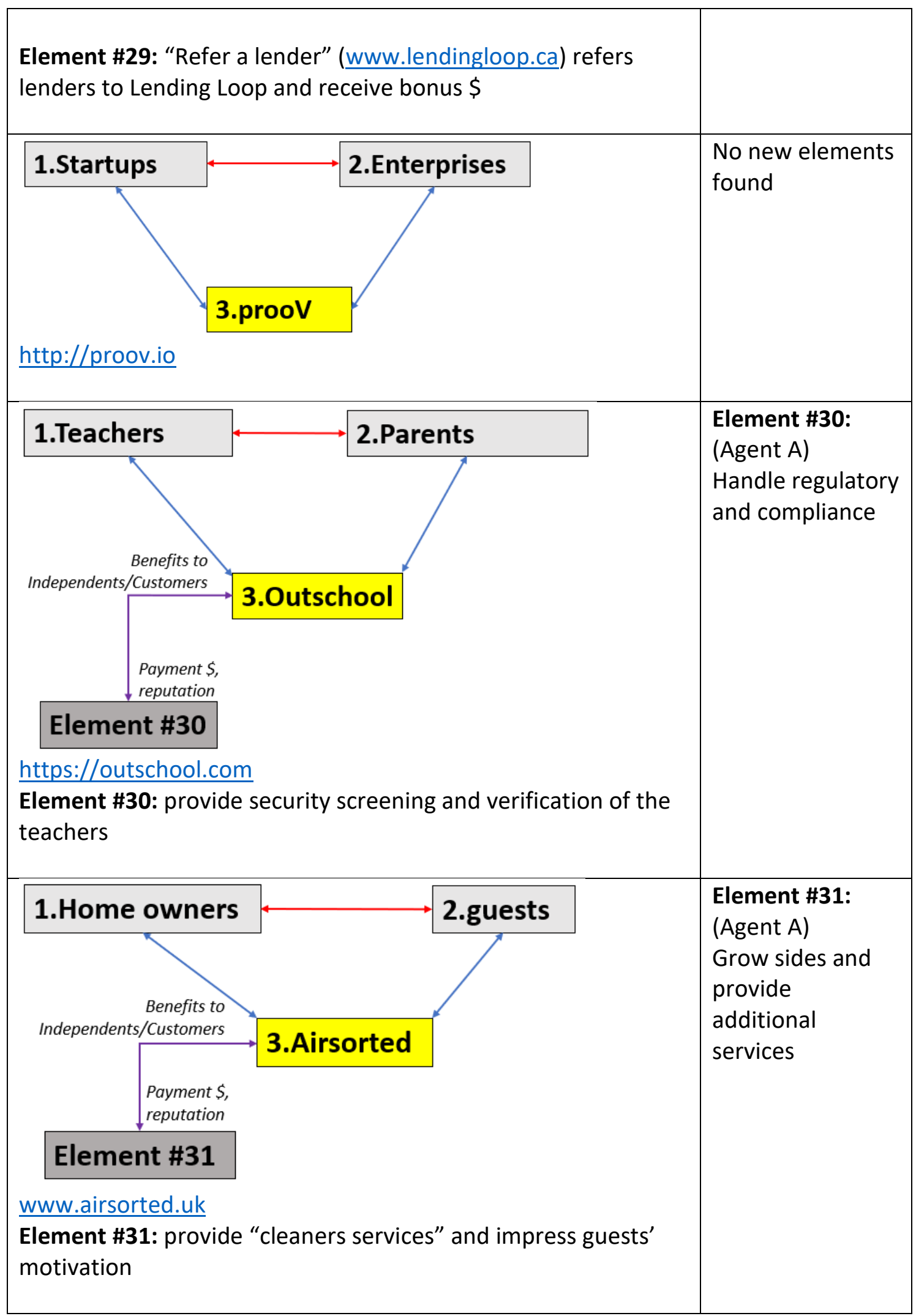




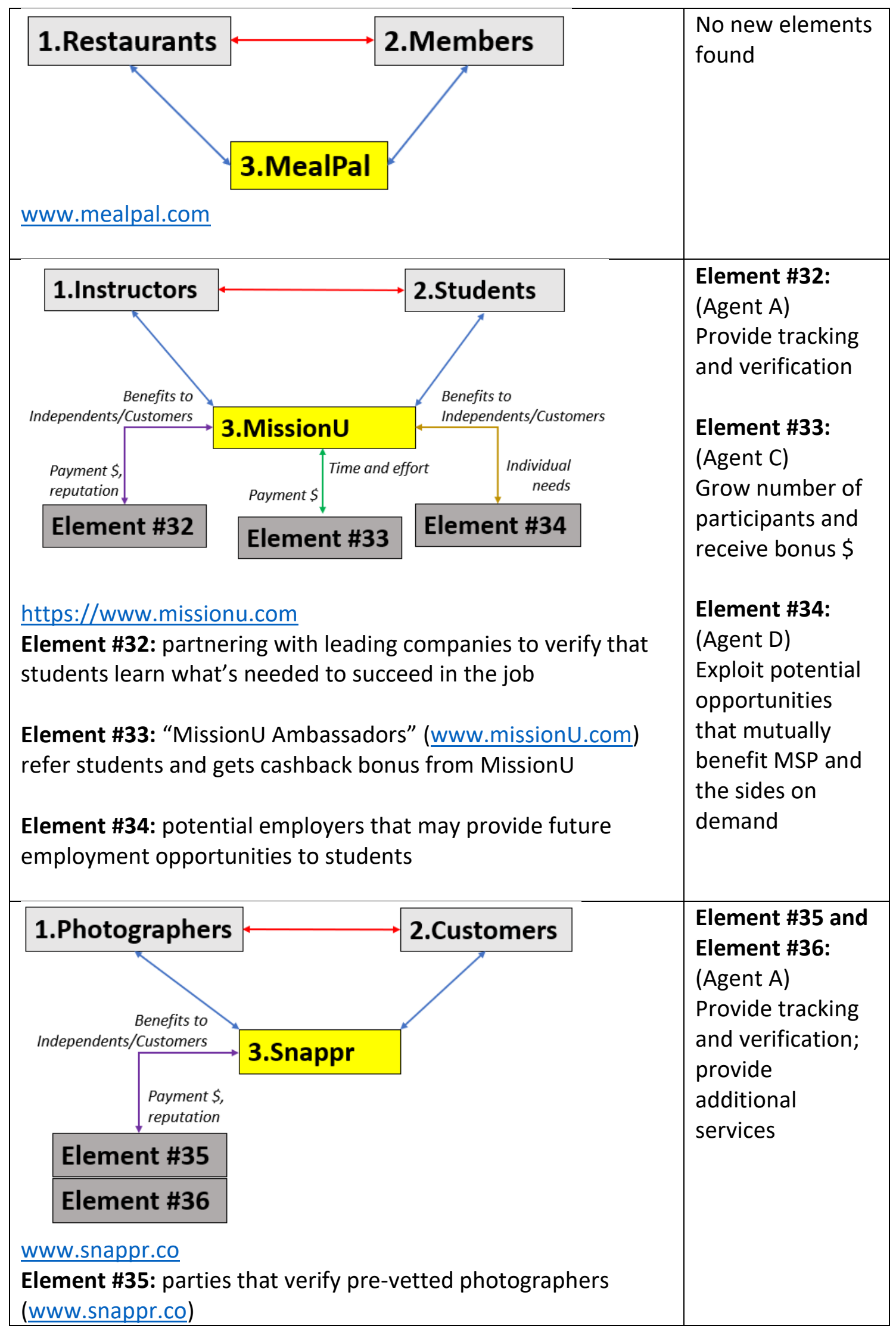


Element \#36: parties that provide professional indemnity insurance for photographers, and insurance covering photography equipment and bookings

\begin{tabular}{|l|l|l|}
\hline New entity and their responsibilities & $\begin{array}{l}\text { Labeled as } \\
\text { theme }\end{array}$ & $\begin{array}{l}\text { Frequency of } \\
\text { occurrence }\end{array}$ \\
\hline $\begin{array}{l}\text { Agent A: } \\
\text { Provide amenities to attract and retain } \\
\text { Catalysts; grow sides; offer additional services; } \\
\text { handle regulatory and compliance; provide } \\
\text { tracking and verification }\end{array}$ & $\begin{array}{l}\text { Agent A: } \\
\text { Third parties }\end{array}$ & $\begin{array}{l}23 \text { elements } \\
\text { found in } 12 \\
\text { companies }\end{array}$ \\
\hline $\begin{array}{l}\text { Agent B: } \\
\text { Strengthen affiliation between Independents } \\
\text { and Customers; induce platform revenue } \\
\text { creating more transactions }\end{array}$ & $\begin{array}{l}\text { Agent B: } \\
\text { Catalysts }\end{array}$ & $\begin{array}{l}\text { 2 elements } \\
\text { found in 2 } \\
\text { companies }\end{array}$ \\
\hline $\begin{array}{l}\text { Agent C: } \\
\text { Grow number of participants that join sides } \\
\text { and receive commissions and bonus \$ from } \\
\text { operators }\end{array}$ & $\begin{array}{l}\text { Agent C: } \\
\text { Affiliates }\end{array}$ & $\begin{array}{l}\text { 8 elements } \\
\text { found in 5 } \\
\text { companies }\end{array}$ \\
\hline $\begin{array}{l}\text { Agent D: } \\
\text { Exploit potential opportunities that mutually } \\
\text { benefit MSP and the sides on demand }\end{array}$ & $\begin{array}{l}\text { Agent D: } \\
\text { Sides on demand }\end{array}$ & $\begin{array}{l}\text { 3 elements } \\
\text { found in 3 } \\
\text { companies }\end{array}$ \\
\hline
\end{tabular}


Appendix 4: Data for the four new agents and four new affiliations collected for 19 companies included in the sample

S1: Instacart (2012) https://www.instacart.com

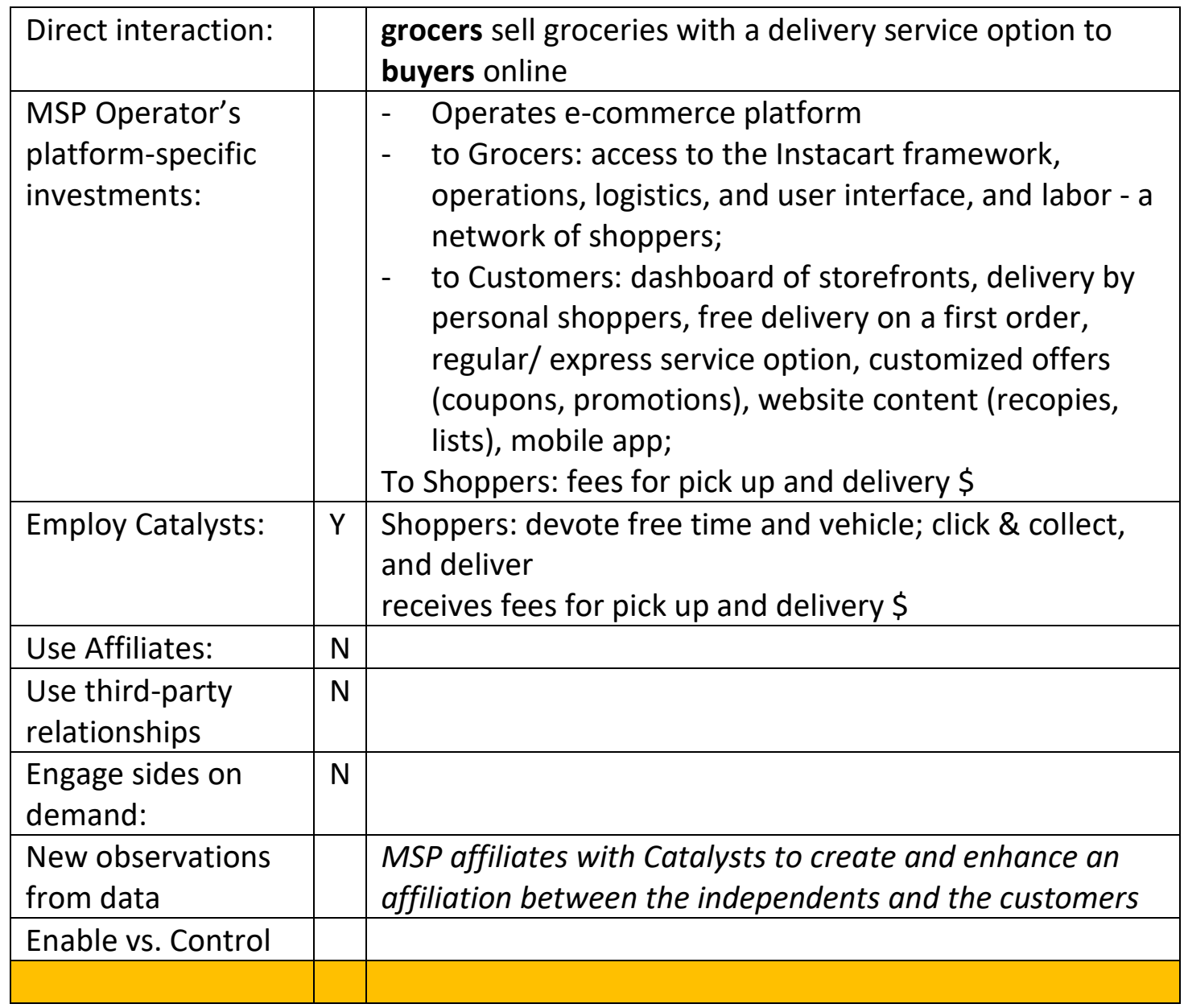

S2: Freightos (2012) https://www.freightos.com

\begin{tabular}{|l|l|l|}
\hline Direct interaction: & $\begin{array}{l}\text { Shippers \& forwarders/carriers generate quotes, share } \\
\text { rates, and find lowest shipping rates \& fastest routes for } \\
\text { e-commerce customers through Software-as-a-Service } \\
\text { platform }\end{array}$ \\
\hline $\begin{array}{l}\text { MSP Operator's } \\
\text { platform-specific } \\
\text { investments: }\end{array}$ & $\begin{array}{l}- \\
\text { Provide Freightos AcceleRate SaaS technology and } \\
\text { free freight shipping tools on site; free access to } \\
\text { platform } \\
\text { to Shippers: quick quotes, speedy response } \\
-\quad \begin{array}{l}\text { to Forwarders/Carriers: fewer wait times } \\
\text { to E-Commerce retailers: automated pricing } \\
\text { to Affiliates: reward \$, personalized web link }\end{array}\end{array}$ \\
\hline
\end{tabular}




\begin{tabular}{|c|c|c|}
\hline Employ Catalysts: & $N$ & \\
\hline Use Affiliates: & $\mathrm{Y}$ & $\begin{array}{l}\text { Affiliates - refer shippers to Freightos } \\
\text { receives reward \$, personalized web link }\end{array}$ \\
\hline $\begin{array}{l}\text { Use third-party } \\
\text { relationships }\end{array}$ & $N$ & \\
\hline $\begin{array}{l}\text { Engage sides on } \\
\text { demand: }\end{array}$ & $N$ & \\
\hline $\begin{array}{l}\text { New observations } \\
\text { from data }\end{array}$ & & $\begin{array}{l}\text { MSP provides technology and tools that (i) enable } \\
\text { independents to generate more revenue, faster; (ii) bring } \\
\text { ease and convenience to customers }\end{array}$ \\
\hline Enable vs. Control & & Shippers give MSP, a percentage of revenue \\
\hline
\end{tabular}

\section{S3: Coursera (2012) http://www.coursera.org}

\begin{tabular}{|c|c|c|}
\hline Direct interaction: & & $\begin{array}{l}\text { course providers offer courses to a diverse audience of } \\
\text { learners online }\end{array}$ \\
\hline $\begin{array}{l}\text { MSP Operator's } \\
\text { platform-specific } \\
\text { investments: }\end{array}$ & & $\begin{array}{l}\text { - Learners: Open to everyone; } 100 \% \text { online or } \\
\text { downloadable content with iOS \& Android apps; } \\
\text { website help; accommodations for learners; Sharable } \\
\text { Course and Specialization Certificates; free-trial } \\
\text { promotion; subscription plans; } \\
\text { - } \quad \text { Educators: } \\
\text { - } \quad \text { Learner support: } \\
\text { - } \quad \text { Developers: access to data feed - metadata; } \\
\text { commission paid on any course purchase originating } \\
\text { from their project; } \\
\text { Affiliates: } 20 \% \text { commission on purchases made } \\
\text { through affiliation; Coursera banners and text links; } \\
\text { newsletter feed; access to Coursera product } \\
\text { merchandiser feed; } \\
\text { Business, Gov \& Org: flexible pricing options, } \\
\text { customized offering }\end{array}$ \\
\hline Employ Catalysts: & $\mathrm{N}$ & \\
\hline Use Affiliates: & $Y$ & $\begin{array}{l}\text { Affiliates - sell courses } \\
\text { receives from MSP - 20\% commission on purchases made } \\
\text { through affiliation; Coursera banners and text links; } \\
\text { newsletter feed; access to Coursera product } \\
\text { merchandiser feed; }\end{array}$ \\
\hline $\begin{array}{l}\text { Use third-party } \\
\text { relationships }\end{array}$ & $Y$ & $\begin{array}{l}\text { Experts \& Enthusiasts - voluntarily explore courses and } \\
\text { give feedback/ verification; } \\
\text { Business, Governments, and Organizations; sponsor } \\
\text { learning communities, progress tracking, and analytics }\end{array}$ \\
\hline
\end{tabular}




\begin{tabular}{|l|l|l|}
\hline & & $\begin{array}{l}\text { Receives from MSP - flexible pricing options, customized } \\
\text { offering }\end{array}$ \\
\hline $\begin{array}{l}\text { Engage sides on } \\
\text { demand: }\end{array}$ & $\mathrm{N}$ & \\
\hline $\begin{array}{l}\text { New observations } \\
\text { from data }\end{array}$ & $\begin{array}{l}\text { MSP operators increase revenue and cohesiveness } \\
\text { between sides by expanding products and services around } \\
\text { the core business; } \\
\text { MSP grows its customer side by affiliating with third } \\
\text { parties }\end{array}$ \\
\hline Enable vs. Control & & MSP distributes payments \\
\hline
\end{tabular}

\section{S4: Cohealo (2012) http://www.cohealo.com}

\begin{tabular}{|c|c|c|}
\hline Direct interaction: & & $\begin{array}{l}\text { health system providers optimize the use of clinical } \\
\text { assets and medical facilities improve access to care by } \\
\text { centralizing clinical assets through a cloud-based } \\
\text { platform }\end{array}$ \\
\hline $\begin{array}{l}\text { MSP Operator's } \\
\text { platform-specific } \\
\text { investments: }\end{array}$ & & $\begin{array}{l}\text { - Provide cloud-based platform supporting logistics } \\
\text { capabilities, and analytics; centralizes all medical } \\
\text { equipment and its data on one platform to track a } \\
\text { health system's equipment across facilities; access to } \\
\text { data through an intuitive app; } \\
\text { - Health system providers and medical facilities: On- } \\
\text { demand access to every asset in the system; Alerts } \\
\text { when new technology is added to the system; benefit } \\
\text { from optimized spend, accelerated cash flow } \\
\text { Medical facilities: customized dashboard; electronic } \\
\text { records to quickly access and locate any piece of medical } \\
\text { equipment; Real-time data and usage analytics, benefit } \\
\text { from optimizing access to care }\end{array}$ \\
\hline Employ Catalysts: & $\mathrm{N}$ & \\
\hline Use Affiliates: & $\mathrm{N}$ & \\
\hline $\begin{array}{l}\text { Use third-party } \\
\text { relationships }\end{array}$ & $\mathrm{N}$ & \\
\hline $\begin{array}{l}\text { Engage sides on } \\
\text { demand: }\end{array}$ & $\mathrm{N}$ & \\
\hline $\begin{array}{l}\text { New observations } \\
\text { from data }\end{array}$ & & $\begin{array}{l}\text { Create new value dimension by motivating independents } \\
\text { to liberate their assets to a larger network (optimal use) }\end{array}$ \\
\hline Enable vs. Control & & \\
\hline
\end{tabular}




\section{S5: Ahalogy (2012) http://ahalogy.com}

\begin{tabular}{|c|c|c|}
\hline Direct interaction: & & $\begin{array}{l}\text { Brands \& content creators grow customers and } \\
\text { consumers maximise their experience through } \\
\text { audience insights uncovered using category trend data }\end{array}$ \\
\hline $\begin{array}{l}\text { MSP Operator's } \\
\text { platform-specific } \\
\text { investments: }\end{array}$ & & $\begin{array}{l}\text { - Deliver category trend data, authentic influencer } \\
\text { content, and social optimization technology; } \\
\text { measurable impressions; provide third-party } \\
\text { tracking; } \\
\text { - Brands \& Agencies: offer MUSE to track content } \\
\text { (free during planning) and BRANDABLES to } \\
\text { uncover audience insights; Sign up for free + } \\
\text { request a demo }\end{array}$ \\
\hline Employ Catalysts: & $\mathrm{N}$ & \\
\hline Use Affiliates: & $\mathrm{N}$ & \\
\hline $\begin{array}{l}\text { Use third-party } \\
\text { relationships }\end{array}$ & $\mathrm{Y}$ & Third party tracking - best high engagement creation \\
\hline $\begin{array}{l}\text { Engage sides on } \\
\text { demand: }\end{array}$ & $N$ & \\
\hline $\begin{array}{l}\text { New observations } \\
\text { from data }\end{array}$ & & $\begin{array}{l}\text { Grow customers of the independents by connecting } \\
\text { with their customers' (customer's customers) data }\end{array}$ \\
\hline Enable vs. Control & & \\
\hline
\end{tabular}

S6: Exitround (2103) https://exitround.com

\begin{tabular}{|c|c|c|}
\hline Direct interaction: & & $\begin{array}{l}\text { company founders (sell-side companies) feature best } \\
\text { company exposure and buyers acquire companies } \\
\text { using a proprietary software algorithm }\end{array}$ \\
\hline $\begin{array}{l}\text { MSP Operator's } \\
\text { platform-specific } \\
\text { investments: }\end{array}$ & & $\begin{array}{l}\text { - } \quad \text { proprietary software algorithms (free services } \\
\text { initially); } \\
\text { - } \quad \text { sell-side: feature companies for exposure, } \\
\text { optimize profile, explore opportunities } \\
\text { - } \quad \text { acquirers: ideal match, consultation with curators } \\
\text { - } \quad \text { curators:? }\end{array}$ \\
\hline Employ Catalysts: & $\mathrm{N}$ & \\
\hline Use Affiliates: & $\mathrm{N}$ & \\
\hline $\begin{array}{l}\text { Use third-party } \\
\text { relationships }\end{array}$ & $\mathrm{Y}$ & Target acquisition curators - consultation with buyers \\
\hline $\begin{array}{l}\text { Engage sides on } \\
\text { demand: }\end{array}$ & $\mathrm{N}$ & \\
\hline
\end{tabular}




\begin{tabular}{|l|l|l|}
\hline $\begin{array}{l}\text { New observations from } \\
\text { data }\end{array}$ & $\begin{array}{l}\text { MSP invest to groom the independents in order to be } \\
\text { bought by the acquirers (customer). Customer invests } \\
\$\end{array}$ \\
\hline Enable vs. Control & & \\
\hline & & \\
\hline
\end{tabular}

\section{S7: DoorDash (2013) www.doordash.com}

\begin{tabular}{|c|c|c|}
\hline Direct interaction: & & $\begin{array}{l}\text { businesses sell food and other items and } \\
\text { customers buy and order delivery online }\end{array}$ \\
\hline $\begin{array}{l}\text { MSP Operator's platform- } \\
\text { specific investments: }\end{array}$ & & $\begin{array}{l}\text { - receive orders, directs them to the restaurant, } \\
\text { and assign a dasher } \\
\text { - Dashers: delivery } \$ \text { and perks } \\
\text { - Restaurants: web interface, mobile app, } \\
\text { delivery logistics, exclusive dasher service; } \\
\text { Customers: delivery status algorithm }\end{array}$ \\
\hline Employ Catalysts: & $Y$ & $\begin{array}{l}\text { Dashers' - pick up and delivery; spare time and car } \\
\text { Receives from MSP - delivery \$ and perks }\end{array}$ \\
\hline Use Affiliates: & $\mathrm{N}$ & \\
\hline $\begin{array}{l}\text { Use third-party } \\
\text { relationships }\end{array}$ & $\mathrm{Y}$ & $\begin{array}{l}\text { Perks to Dashers - Auto Insurance | Health care } \\
\text { coverage | Everlance App | Daily Pay| }\end{array}$ \\
\hline Engage sides on demand: & $\mathrm{N}$ & \\
\hline $\begin{array}{l}\text { New observations from } \\
\text { data }\end{array}$ & & $\begin{array}{l}\text { MSP's employ Catalysts to enhance the affiliation } \\
\text { between the independents and the customers; } \\
\text { MSP provides amenities to attract and retain their } \\
\text { agents, by affiliating with third parties }\end{array}$ \\
\hline Enable vs. Control & & \\
\hline
\end{tabular}

S8: FarmLead (2013) https://farmlead.com

\begin{tabular}{|c|c|c|}
\hline Direct interaction: & & $\begin{array}{l}\text { farmers and verified buyers list, negotiate and finalize } \\
\text { grain deals online }\end{array}$ \\
\hline $\begin{array}{l}\text { MSP Operator's } \\
\text { platform-specific } \\
\text { investments: }\end{array}$ & & $\begin{array}{l}\text { MSP' } \\
\text { - Watchlists and notifications; grain tests and } \\
\text { negotiations including basis negotiations; market } \\
\text { analysis, seminars \& conferences; CEO's daily note } \\
\text { on price drivers; } \\
\text { - } \quad \text { To farmers: Grain calculator, and access to grain } \\
\quad \text { testing labs - created GrainTests.com }\end{array}$ \\
\hline Employ Catalysts: & $\mathrm{N}$ & \\
\hline Use Affiliates: & $\mathrm{N}$ & \\
\hline
\end{tabular}




\begin{tabular}{|l|l|l|}
\hline $\begin{array}{l}\text { Use third party } \\
\text { relationships }\end{array}$ & $\mathrm{Y}$ & $\begin{array}{l}\text { Buyers verification and credit check, Grain testing labs } \\
\text { service }\end{array}$ \\
\hline $\begin{array}{l}\text { Engage sides on } \\
\text { demand: }\end{array}$ & $\mathrm{N}$ & \\
\hline $\begin{array}{l}\text { New observations } \\
\text { from data }\end{array}$ & & $\begin{array}{l}\text { MSP earns a variable fee upon transaction while } \\
\text { payment method is agreed upon directly between the } \\
\text { buyer and the seller }\end{array}$ \\
\hline Enable vs. Control & & \\
\hline & & \\
\hline
\end{tabular}

S9: Guesty (2013) www.guesty.com

\begin{tabular}{|c|c|c|}
\hline $\begin{array}{l}\text { Direct } \\
\text { interaction: }\end{array}$ & & $\begin{array}{l}\text { property management companies } \& \text { Airbnb hosts with } \\
\text { multiple accounts efficiently manage all of their businesses } \\
\text { with guests on one platform through a cloud-based } \\
\text { software solution }\end{array}$ \\
\hline $\begin{array}{l}\text { MSP Operator's } \\
\text { platform-specific } \\
\text { investments: }\end{array}$ & & $\begin{array}{l}\text { MSP' } \\
\text { - PRODUCT: property management software; channel } \\
\text { management; unified inbox; automation tools; } \\
\text { powerful reporting; staff management app; } \\
\text { personalized website; payment processing; } 24 / 7 \text { guest } \\
\text { communication } \\
\text { - } \quad \text { To hosts: distribute the listings of all major OTAs; } \\
\text { guarantees that owner will never miss a booking and } \\
\text { increases visibility; all information on Guesty } \\
\text { dashboard; Assign and manage entire team's tasks and } \\
\text { work schedule; maximize revenue; centralize and } \\
\text { automate hosts' activities } \\
\text { - One-on-one live demo on request | Academy }\end{array}$ \\
\hline Employ Catalysts: & $\mathrm{N}$ & \\
\hline Use Affiliates: & $\mathrm{N}$ & \\
\hline $\begin{array}{l}\text { Use third party } \\
\text { relationships }\end{array}$ & $\mathrm{N}$ & \\
\hline $\begin{array}{l}\text { Engage sides on } \\
\text { demand: }\end{array}$ & $\mathrm{N}$ & \\
\hline $\begin{array}{l}\text { New observations } \\
\text { from data }\end{array}$ & & $\begin{array}{l}\text { MSP enables HOSTs to thrive a business by providing a } \\
\text { product portfolio; MSP does not connect with third parties } \\
\text { but allows hosts to connect with third } \\
\text {-party channels for bookings and manage interactions with } \\
\text { third party services; }\end{array}$ \\
\hline \multicolumn{3}{|l|}{ Enable vs. Control } \\
\hline & & \\
\hline
\end{tabular}




\section{S10: Pillow (2014) http://www.pillow.com}

\begin{tabular}{|c|c|c|}
\hline Direct interaction: & & $\begin{array}{l}\text { building owners allow compliant, transparent short-term } \\
\text { revenue-shared rentals and residents earn an extra } \\
\text { income with an end-to-end hosting solution through } \\
\text { automated property and guest management services }\end{array}$ \\
\hline $\begin{array}{l}\text { MSP Operator's } \\
\text { platform-specific } \\
\text { investments: }\end{array}$ & & $\begin{array}{l}\text { MSP' } \\
\text { - automate marketing, guest management, key } \\
\text { exchange, and turnover service; dashboard summary } \\
\text { for unit level detail for entire property portfolio; Live } \\
\text { demo } \\
\text { - to building owners: monitor platform usage; access to } \\
\text { reporting dashboards; } \\
\text { to residents: advocate end-to-end hosting solution, a full- } \\
\text { service solution; }\end{array}$ \\
\hline Employ Catalysts: & $\mathrm{N}$ & \\
\hline Use Affiliates: & $\mathrm{N}$ & \\
\hline $\begin{array}{l}\text { Use third party } \\
\text { relationships }\end{array}$ & $\mathrm{N}$ & \\
\hline $\begin{array}{l}\text { Engage sides on } \\
\text { demand: }\end{array}$ & $\mathrm{Y}$ & $\begin{array}{l}\text { MSP affiliates with sides on demand to actuate MSP } \\
\text { customers' business }\end{array}$ \\
\hline \multicolumn{3}{|l|}{$\begin{array}{l}\text { New observations } \\
\text { from data }\end{array}$} \\
\hline Enable vs. Control & & \\
\hline & & \\
\hline
\end{tabular}

S11: Helpling (2014) https://www.helpling.de

\begin{tabular}{|c|c|c|}
\hline Direct interaction: & & $\begin{array}{l}\text { cleaning aids offer household services and customers } \\
\text { search and book cleaning aids on-demand online }\end{array}$ \\
\hline $\begin{array}{l}\text { MSP Operator's } \\
\text { platform-specific } \\
\text { investments: }\end{array}$ & & $\begin{array}{l}\text { MSP' } \\
\text { - provide tested and insured cleaning aids; operates } \\
\text { the platform, accepts booking requests; handles } \\
\text { Rebookings and cancellations of customers; } \\
\text { - Customers: no platform usage fee; cleaning aids } \\
\text { insured against liability, security; good conduct and } \\
\text { the trade license; payments } 20 \% \text { tax deductible; } \\
\text { arrange special requests with cleaning staff; priorities } \\
\text { checklist; Guide + FAQ } \\
\text { Cleaners: get cleaning jobs in their area; earnings into } \\
\text { their accounts every two weeks; }\end{array}$ \\
\hline Employ Catalysts: & $\mathrm{N}$ & \\
\hline Use Affiliates: & $\mathrm{N}$ & \\
\hline
\end{tabular}




\begin{tabular}{|l|l|l|}
\hline $\begin{array}{l}\text { Use third-party } \\
\text { relationships }\end{array}$ & $\mathrm{Y}$ & $\begin{array}{l}\text { provides other household-related services through } \\
\text { partner companies; cleaners safety records, trade } \\
\text { licenses }\end{array}$ \\
\hline $\begin{array}{l}\text { Engage sides on } \\
\text { demand: }\end{array}$ & $\mathrm{N}$ & \\
\hline $\begin{array}{l}\text { New observations } \\
\text { from data }\end{array}$ & $\begin{array}{l}\text { MSP enables a marketplace for professionals to do } \\
\text { business, ensure quality and trust, and control } \\
\text { transactions }\end{array}$ \\
\hline Enable vs. Control & & \\
\hline
\end{tabular}

S12: Thrive Market (2014) https://thrivemarket.com

\begin{tabular}{|c|c|c|}
\hline Direct interaction: & & $\begin{array}{l}\text { brands sell healthy foods and natural products at } \\
\text { wholesale prices to members online }\end{array}$ \\
\hline $\begin{array}{l}\text { MSP Operator's } \\
\text { platform-specific } \\
\text { investments: }\end{array}$ & & $\begin{array}{l}\text { MSP' - wholesale prices, and to sponsor free } \\
\text { memberships; offer custom educational content; } \\
\text { - } \quad \text { To families: free } 30 \text {-day membership trial; register } \\
\text { for free, } 15 \% \text { off the first purchase; annual } \\
\text { membership - 20\% off first } 3 \text { purchases; orders } \\
\text { over \$49 ships free; } \\
\text { - } \quad \text { To beneficiary families: free membership; } \\
\text { - } \quad \text { Affiliate partners: \$25 for introducing a friend; a } \\
\text { custom link, sample posts, banners, and images; a } \\
\text { secure account with a dashboard to track progress } \\
\text { - Free trial + Guide + FAQ }\end{array}$ \\
\hline Employ Catalysts: & $\mathrm{N}$ & \\
\hline Use Affiliates: & $\mathrm{Y}$ & Affiliates: spread the word - drive members \\
\hline $\begin{array}{l}\text { Use third-party } \\
\text { relationships }\end{array}$ & $\mathrm{Y}$ & $\begin{array}{l}\text { Distribute free memberships through NPOs; Advocacy } \\
\text { campaigns; }\end{array}$ \\
\hline $\begin{array}{l}\text { Engage sides on } \\
\text { demand: }\end{array}$ & $Y$ & $\begin{array}{l}\text { Identify and maintain a list of potential recipients for } \\
\text { free-membership; }\end{array}$ \\
\hline $\begin{array}{l}\text { New observations } \\
\text { from data }\end{array}$ & & $\begin{array}{l}\text { MSP reach out to larger community (side) by fulfilling a } \\
\text { social need, (free memberships and donor } \$ \text { to low } \\
\text { income families) }\end{array}$ \\
\hline \multicolumn{3}{|l|}{ Enable vs. Control } \\
\hline & & \\
\hline
\end{tabular}

S13: Lending Loop (2014) www.lendingloop.ca

\begin{tabular}{|l|l|l|l}
\hline Direct interaction: & lenders risk managed lending and small businesses
\end{tabular} affordable financing through the online process 


\begin{tabular}{|c|c|c|}
\hline $\begin{array}{l}\text { MSP Operator's } \\
\text { platform-specific } \\
\text { investments: }\end{array}$ & & $\begin{array}{l}\text { MSP' } \\
\text { - } \quad \text { assess lender's investor preferences and risk } \\
\text { tolerance, investment objectives and current } \\
\text { financial position; evaluate the loan request, assign } \\
\text { risk rating, to creditworthy borrowers; } \\
\text { - } \quad \text { For lenders: deposit monthly payments collected } \\
\text { from borrowers; } \\
\text { - } \quad \text { For borrowers: “borrower's Guide” } \\
\text { - } \quad \text { For partners: Distributor Ps - provide for their } \\
\quad \text { clients LL services; Referral Ps - commission; } \\
\text { Affiliate Ps - commission; Vendor Ps - sales; } \\
\text { - } \quad \text { Refer a lender: \$25 }\end{array}$ \\
\hline Employ Catalysts: & $\mathrm{N}$ & \\
\hline Use Affiliates: & $\mathrm{Y}$ & $\begin{array}{l}\text { Referral Ps - refer business owners to LL; Affiliate Ps - } \\
\text { publish content and refer readers to LL; } \\
\text { Refer a lender: refer a friend to LL for lending }\end{array}$ \\
\hline $\begin{array}{l}\text { Use third-party } \\
\text { relationships }\end{array}$ & $\mathrm{Y}$ & $\begin{array}{l}\text { Partners' - Distributor Ps - introduce their clients to LL } \\
\text { services; Vendor Ps - sell products to businesses } \\
\text { through LL financing; } \\
\text { uses a Canadian Chartered Bank to handle all money } \\
\text { that is stored through platform; registered as an Exempt } \\
\text { Market Dealer in all provinces and territories; }\end{array}$ \\
\hline $\begin{array}{l}\text { Engage sides on } \\
\text { demand: }\end{array}$ & $\mathrm{N}$ & \\
\hline $\begin{array}{l}\text { New observations } \\
\text { from data }\end{array}$ & & $\begin{array}{l}\text { MSP uses third parties to handle regulatory and } \\
\text { compliance matters }\end{array}$ \\
\hline \multicolumn{3}{|l|}{ Enable vs. Control } \\
\hline & & \\
\hline
\end{tabular}

S14: prooV (2015) http://proov.io

\begin{tabular}{|c|c|}
\hline $\begin{array}{l}\text { Direct } \\
\text { interaction: }\end{array}$ & $\begin{array}{l}\text { startups and enterprises facilitate proof-of-Concept } \\
\text { process through Pilot-as-a-service platform }\end{array}$ \\
\hline $\begin{array}{l}\text { MSP Operator's } \\
\text { platform-specific } \\
\text { investments: }\end{array}$ & $\begin{array}{l}\text { MSP' } \\
\text { - Provide Pilot-as-a-Service platform - to facilitate PoC's; } \\
\text { provide License to access and use the services; various } \\
\text { data sets; } \\
\text { - Enterprises: access to pre-screened startups/ ISVs and } \\
\text { PoC opportunities; } \\
\text { - Startups: Access to PoC ready enterprises and } \\
\text { everything needed to run a winning PoC - RFPs, APIs, } \\
\text { data, systems, etc.; dedicated company profile page; } \\
\text { Enterprise's complete system specs; Direct chat }\end{array}$ \\
\hline
\end{tabular}




\begin{tabular}{|l|l|l|}
\hline & & $\begin{array}{c}\text { channel; Remote connection to the testing } \\
\text { environment }\end{array}$ \\
\hline Employ Catalysts: & $\mathrm{N}$ & \\
\hline Use Affiliates: & $\mathrm{N}$ & \\
\hline $\begin{array}{l}\text { Use third party } \\
\text { relationships }\end{array}$ & $\mathrm{N}$ & \\
\hline $\begin{array}{l}\text { Engage sides on } \\
\text { demand: }\end{array}$ & $\mathrm{N}$ & \\
\hline $\begin{array}{l}\text { New } \\
\text { observations } \\
\text { from data }\end{array}$ & $\begin{array}{l}\text { MSP invest to groom the independents in order to be } \\
\text { bought by the enterprises (customer). Customer invests \$; } \\
\text { operators sometimes lay down mandatory requirements } \\
\text { (prerequisites) for sides to participate }\end{array}$ \\
\hline $\begin{array}{l}\text { Enable vs. } \\
\text { Control }\end{array}$ & & \\
\hline & & \\
\hline
\end{tabular}

S15: Outschool (2015) https://outschool.com

\begin{tabular}{|c|c|c|}
\hline Direct interaction: & & $\begin{array}{l}\text { teachers offer and sell virtual classes and parents (on } \\
\text { behalf of children) find, book and pay for classes online }\end{array}$ \\
\hline $\begin{array}{l}\text { MSP Operator's } \\
\text { platform-specific } \\
\text { investments: }\end{array}$ & & $\begin{array}{l}\text { MSP' } \\
\text { - the availability of the Site; serve as the limited agent } \\
\text { of each Teacher for accepting payments from a } \\
\text { Parent; reject, remove any Classes from the } \\
\text { marketplace, edit the class description; screen } \\
\text { teachers; Video + FAQ } \\
\text { - teachers: transfer the Teacher Fees to their Paypal } \\
\text { account; } \\
\text { - parents: act on behalf of the Parent, for the adequacy } \\
\text { and satisfactory service by teachers }\end{array}$ \\
\hline Employ Catalysts: & $\mathrm{N}$ & \\
\hline Use Affiliates: & $\mathrm{N}$ & \\
\hline $\begin{array}{l}\text { Use third party } \\
\text { relationships }\end{array}$ & $\mathrm{Y}$ & Screening and verification of teachers \\
\hline $\begin{array}{l}\text { Engage sides on } \\
\text { demand: }\end{array}$ & $\mathrm{N}$ & \\
\hline $\begin{array}{l}\text { New observations } \\
\text { from data }\end{array}$ & & $\begin{array}{l}\text { MSP enables a marketplace for professionals to do } \\
\text { business, and control transactions; } \\
\text { operators sometimes lay down mandatory requirements } \\
\text { (prerequisites) for sides to participate; }\end{array}$ \\
\hline
\end{tabular}




\begin{tabular}{|l|l|l|}
\hline & $\begin{array}{l}\text { MSP serves as the limited agent for independent side, } \\
\text { teachers, and acts on behalf of the subject (consumer) for } \\
\text { satisfactory service by teachers }\end{array}$ \\
\hline Enable vs. Control & & \\
\hline & & \\
\hline
\end{tabular}

S16: Airsorted (2015) www.airsorted.uk

\begin{tabular}{|l|l|l|}
\hline Direct interaction: & $\begin{array}{l}\text { Homeowners let their homes to guests without being a } \\
\text { host }\end{array}$ \\
\hline $\begin{array}{l}\text { MSP Operator's } \\
\text { platform-specific } \\
\text { investments: }\end{array}$ & $\begin{array}{l}\text { MSP' } \\
-\quad \begin{array}{l}\text { Hosts: home inspection, lockbox, listing creation: } \\
\text { professional photography and SEO; organize } \\
\text { professional cleaners, linens, and towels; Guest } \\
\text { vetting; account management; price optimization } \\
\text { Guests: guest communication; 24hrs check-in; } \\
\text { replenishments; provide cleaning service; }\end{array}\end{array}$ \\
\hline Employ Catalysts: & $\mathrm{N}$ & $\mathrm{N}$ \\
\hline Use Affiliates: & $\mathrm{Y}$ & Cleaners service to impress customers \\
relationships & $\mathrm{N}$ & \\
\hline $\begin{array}{l}\text { Engage sides on } \\
\text { demand: }\end{array}$ & $\mathrm{N}$ & $\begin{array}{l}\text { MSP manages assets and generates demand on behalf of } \\
\text { one side to attract the customer side }\end{array}$ \\
\hline $\begin{array}{l}\text { New observations } \\
\text { from data }\end{array}$ & & \\
\hline Enable vs. Control & & \\
\hline
\end{tabular}

S17: MealPal (2016) www.mealpal.com

\begin{tabular}{|l|l|l|}
\hline Direct interaction: & & $\begin{array}{l}\text { restaurants offer monthly subscription meal plans to } \\
\text { members online }\end{array}$ \\
\hline $\begin{array}{l}\text { MSP Operator's } \\
\text { platform-specific } \\
\text { investments: }\end{array}$ & $\begin{array}{l}\text { MSP' - subscription meal plans for <\$6 per meal; } \\
\text { promotional plans, trial membership }\end{array}$ \\
\hline Employ Catalysts: & $\mathrm{N}$ & \\
\hline Use Affiliates: & $\mathrm{N}$ & \\
\hline $\begin{array}{l}\text { Use third party } \\
\text { relationships }\end{array}$ & $\mathrm{N}$ & \\
\hline $\begin{array}{l}\text { Engage sides on } \\
\text { demand: }\end{array}$ & $\mathrm{N}$ & \\
\hline
\end{tabular}




\begin{tabular}{|l|l|l|}
\hline $\begin{array}{l}\text { New observations from } \\
\text { data }\end{array}$ & $\begin{array}{l}\text { MSP decides the fee structure and offer long-term } \\
\text { commitment to attracting customers (increase } \\
\text { switching costs to members) }\end{array}$ \\
\hline Enable vs. Control & & \\
\hline & & \\
\hline
\end{tabular}

S18: MissionU (2016) https://www.missionu.com

\begin{tabular}{|c|c|c|}
\hline Direct interaction: & & $\begin{array}{l}\text { Instructors \& industry experts facilitate industry } \\
\text { informed curriculum-based learning to students } \\
\text { through live sessions online }\end{array}$ \\
\hline $\begin{array}{l}\text { MSP Operator's } \\
\text { platform-specific } \\
\text { investments: }\end{array}$ & & $\begin{array}{l}\text { MSP' } \\
\text { - } \quad \text { uniquely immersive, collaborative, and efficient } \\
\text { learning experience, industry informed curriculum; } \\
\text { - } \quad \text { students: in-person activities, structured projects, } \\
\text { team projects, technical skills, work experience, } \\
\text { resume build \& career launch; Program + sign up | } \\
\text { How to apply } \\
\text { - } \quad \text { experts \& Academics:? } \\
\text { - } \quad \text { Ambassadors: cash back bonus for referrals } \\
\text { - } \quad \text { Employers: get access to graduates }\end{array}$ \\
\hline Employ Catalysts: & $\mathrm{N}$ & \\
\hline Use Affiliates: & $Y$ & $\begin{array}{l}\text { Affiliates (MissionU ambassadors) refer students; gets a } \\
\text { cash back bonus in return }\end{array}$ \\
\hline $\begin{array}{l}\text { Use third-party } \\
\text { relationships }\end{array}$ & $Y$ & $\begin{array}{l}\text { Partner with leading companies to verify students learn } \\
\text { what's needed to succeed in the job }\end{array}$ \\
\hline $\begin{array}{l}\text { Engage sides on } \\
\text { demand: }\end{array}$ & $Y$ & $\begin{array}{l}\text { Connect with employers to provide future employment } \\
\text { opportunities to students }\end{array}$ \\
\hline $\begin{array}{l}\text { New observations } \\
\text { from data }\end{array}$ & & $\begin{array}{l}\text { MSP invests in customers expecting to capture revenue } \\
\text { ex-post: Customers' platform specific contribution is } \\
\text { contractual and ex-post }\end{array}$ \\
\hline \multicolumn{3}{|l|}{ Enable vs. Control } \\
\hline & & \\
\hline
\end{tabular}

S19: Snappr (2016) www.snappr.co

\begin{tabular}{|l|l|l|}
\hline $\begin{array}{l}\text { Direct } \\
\text { interaction: }\end{array}$ & $\begin{array}{l}\text { photographers offer onsite services and customers book } \\
\text { pre-vetted on demand photographers online }\end{array}$ \\
\hline $\begin{array}{l}\text { MSP Operator's } \\
\text { platform-specific } \\
\text { investments: }\end{array}$ & $\begin{array}{l}\text { MSP' - facilitate the availability of the Site; serve as the } \\
\text { limited agent of each Photographer for the purpose of } \\
\text { accepting payments from customer; }\end{array}$ \\
\hline
\end{tabular}




\begin{tabular}{|c|c|c|}
\hline & & $\begin{array}{l}\text { - Photographers: fortnightly payments; provide insurance } \\
\text { for all bookings, photography equipment theft-damage- } \\
\text { loss, public liability and professional indemnity (in } \\
\text { Australia); } \\
\text { - Customers: option to choose photographers; discounts } \\
\text { for bulk purchases; full copyright ownership; receive } \\
\text { photos online within } 3 \text { days, 7-10 days on print; can } \\
\text { book up to } 12 \text { hours in advance; act on behalf of the } \\
\text { Subject for satisfactory service by the photographer; } \\
\text { How it works + FAQ }\end{array}$ \\
\hline $\begin{array}{l}\text { Employ } \\
\text { Catalysts: }\end{array}$ & $\mathrm{N}$ & \\
\hline Use Affiliates: & $\mathrm{N}$ & \\
\hline $\begin{array}{l}\text { Use third party } \\
\text { relationships }\end{array}$ & $Y$ & $\begin{array}{l}\text { Pre-vetted photographers; professional indemnity } \\
\text { insurance, and insurance over photography equipment and } \\
\text { bookings }\end{array}$ \\
\hline $\begin{array}{l}\text { Engage sides on } \\
\text { demand: }\end{array}$ & $\mathrm{N}$ & \\
\hline $\begin{array}{l}\text { New } \\
\text { observations } \\
\text { from data }\end{array}$ & & $\begin{array}{l}\text { MSP serves as the limited agent for independent side, } \\
\text { photographers, and acts on behalf of the subject (consumer) } \\
\text { for satisfactory service by photographer; } \\
\text { operators sometimes lay down mandatory requirements } \\
\text { (prerequisites) for sides to participate }\end{array}$ \\
\hline $\begin{array}{l}\text { Enable vs. } \\
\text { Control }\end{array}$ & & \\
\hline & & \\
\hline
\end{tabular}




\section{REFERENCES:}

Boudreau, K. and Hagiu, A. 2008. Platform Rules: Multi-Sided Platforms as Regulators. Available at: SSRN. https://ssrn.com/abstract=1269966 or http://dx.doi.org/10.2139/ssrn.1269966

Eisenmann, T., Parker, G. and Van Alstyne, M.W. 2006. Strategies for two-sided markets. Harvard Business Review, 84(10), pp.92-101.

Evans, D.S. 2009. How catalysts ignite: the economics of platform-based start-ups. In: Platforms, markets and innovation, Cheltenham, UK and Northampton, MA, US: Edward Elgar, pp.99-128.

Evans, D.S. 2016. Multisided Platforms, Dynamic Competition, and the Assessment of Market Power for Internet-Based Firms. University of Chicago Coase-Sandor Institute for Lawa \& Economics Research Paper No.753. Available at: SSRN. https://ssrn.com/abstract=2746095

Evans, D.S. and Schmalensee, R. 2016. Matchmakers: The New Economics of Multisided Platforms. Harvard Business Review Press. Robert Pindyck.

Gawer, A. 2009. An introduction. In: Platforms, markets, and innovation, Edward Elgar Publishing.

Gibbons, R. 2005. Four formal(izable) theories of the firm?. Journal of Economic Behavior \& Organization, 58(2), pp.200-245.

Hagiu, A. 2004. Two-sided platforms: Pricing and social efficiency. RIETI Discussion Paper Series. December 2004 04-E-035. Available at:

https://www.rieti.go.jp/ip/publications/dp/04e035.pdf 
Hagiu, A. 2006. Proprietary vs. open two-sided platforms and social efficiency. Available at: SSRN. https://ssrn.com/abstract=980755 or http://dx.doi.org/10.2139/ssrn.980755 Hagiu, A. 2007. Merchant or Two-Sided Platform?. Review of Network Economics, 6(2), pp.115-133.

Hagiu, A. 2009. Two-Sided Platforms: Product Variety and Pricing Structures. Journal of Economics \& Management Strategy, 18(4), pp.1011-1043.

Hagiu, A. 2014. Strategic decisions for multisided platforms. MIT Sloan Management Review, 55(2), pp.71-80.

Hagiu, A. and Altman, J.A. 2017. Finding the Platform in Your Product. Harvard Business Review, 95(4), pp.94-100.

Hagiu, A. and Hałaburda, H. 2014. Information and two-sided platform profits. International Journal of Industrial Organization, 34, pp.25-35.

Hagiu, A. and Wright, J. 2015a. Marketplace or reseller?. Management Science, 61(1), pp.184-203.

Hagiu, A. and Wright, J. 2015b. Multi-sided platforms. International Journal of Industrial Organization, 43, pp.162-174.

Hagiu, A. and Wright, J. 2015c. Enabling Versus Controlling. Harvard Business School Working Paper, No. 16-002, July 2015. (Revised October 2015.) HBS case. 13 July 2016. http://hbswk.hbs.edu/item/how-uber-airbnb-and-etsyattracted-their-first-1-000-customers 
http://www.businessinsider.com/38-hottest-startups-to-watch-in-2017-2016-

11/\#exabeam-rooting-out-internal-hacker-spies-1

http://www.ventureforcanada.ca/partner-companies/

https://venturebeat.com/2014/01/07/marketplace-companies-to-watch/

https://www.bloomberg.com

https://www.crunchbase.com/

https://www.entrepreneur.com/article/42336

https://www.investopedia.com/exam-guide/cfa-level-1/alternative-

investments/venture-capital-investing-stages.asp

https://www.investopedia.com/terms/d/debtfinancing.asp

https://www.investopedia.com/terms/i/initial-coin-offering-ico.asp

https://www.owler.com/

https://www.seedinvest.com/blog/startup-investing/how-convertible-notes-work

https://www.tutorialspoint.com/object oriented analysis design/ooad object orie

nted_analysis.htm

Parker, G.G., Van Alstyne, M.W. and Choudary, S.P. 2016. Platform revolution: How networked markets are transforming the economy and how to make them work for you. WW Norton \& Company.

Staykova, K.S., and Damsgaard, J. 2015. A Typology of Multi-sided Platforms: The Core and the Periphery. In: 23rd European Conference on Information Systems (ECIS) 2015. 
Tan, B., Pan, S.L., Lu, X. and Huang, L. 2015. The Role of IS Capabilities in the Development of Multi-Sided Platforms: The Digital Ecosystem Strategy of Alibaba. com. Journal of the Association for Information Systems, 16(4), pp.248-280.

Wang, D. and Nicolau, J.L. 2017. Price Determinants of Sharing Economy Based Accommodation Rental: A study of listings from 33 cities on Airbnb.com. International Journal of Hospitality Management, 62, pp.120-131.

Yin, R.K. 2018. Case Study Research and Applications: design and methods. Sixth edition. Los Angeles. SAGE [2018] 